
630.7 I $66 \mathrm{~b}$ no.766 cop. 8 


\section{UNIVERSITY OF \\ ILLINOIS LIBRARY \\ AT URBANA.CHAMPAIGN \\ AGRICULTURE}




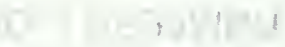

M $1.1=-1.1$.

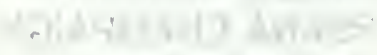

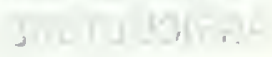




\section{Soybean Movemenis}

North Central Regional Research Publication No. 273

Southern Cooperative Series Bulletin 251

Illinois Bulletin 766

Agricultural Experiment Station

College of Agriculture

University of Illinois at Urbana-Champaign
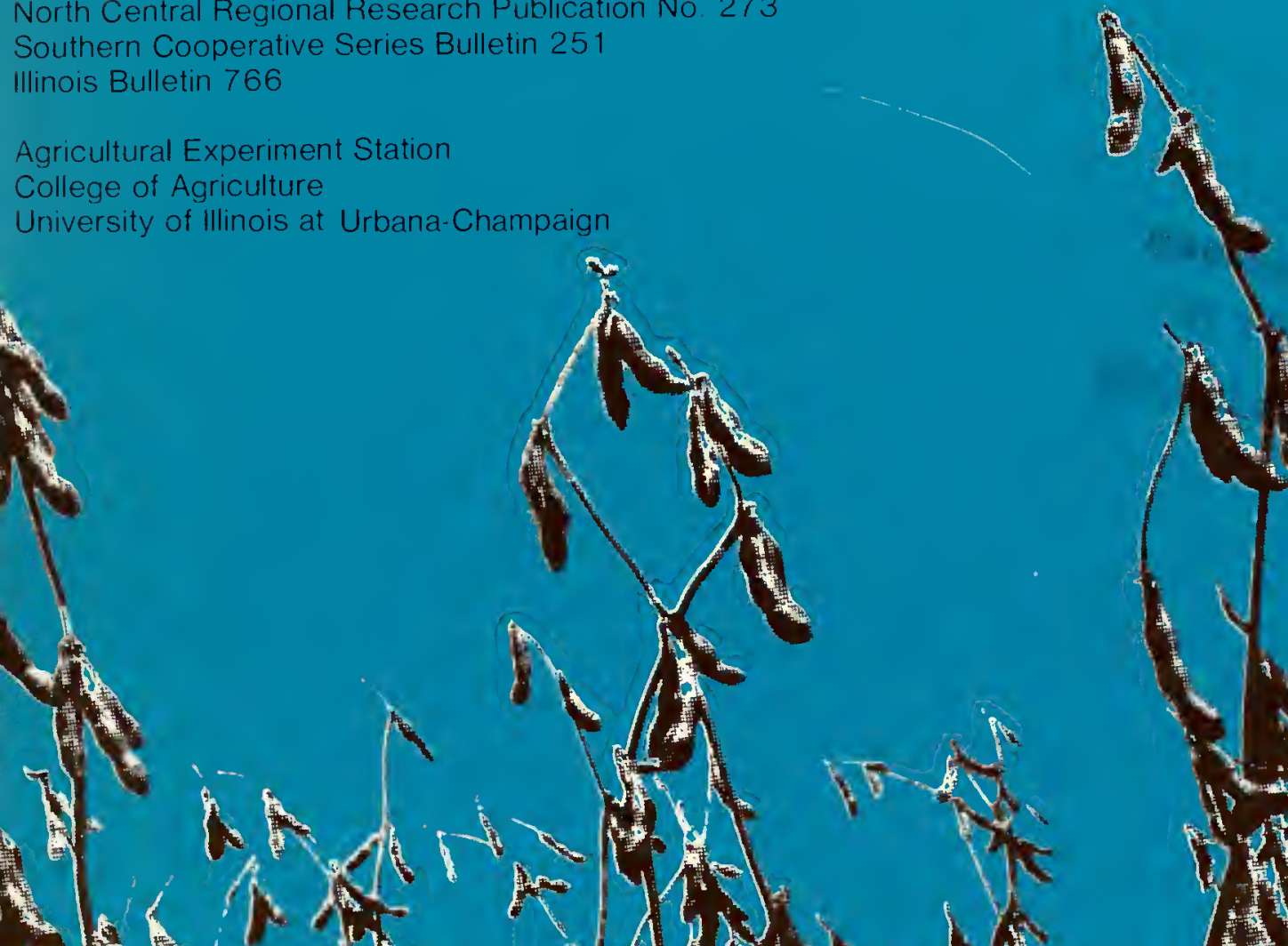

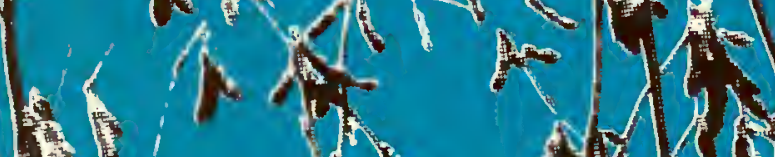

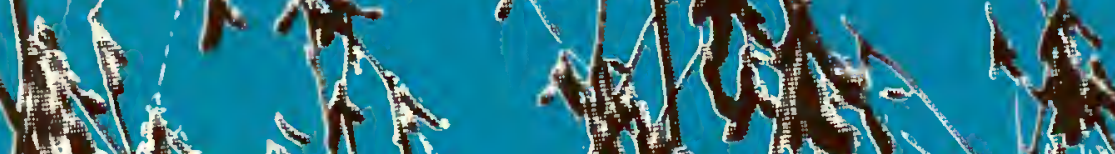
Me $9 y$ 3.

)
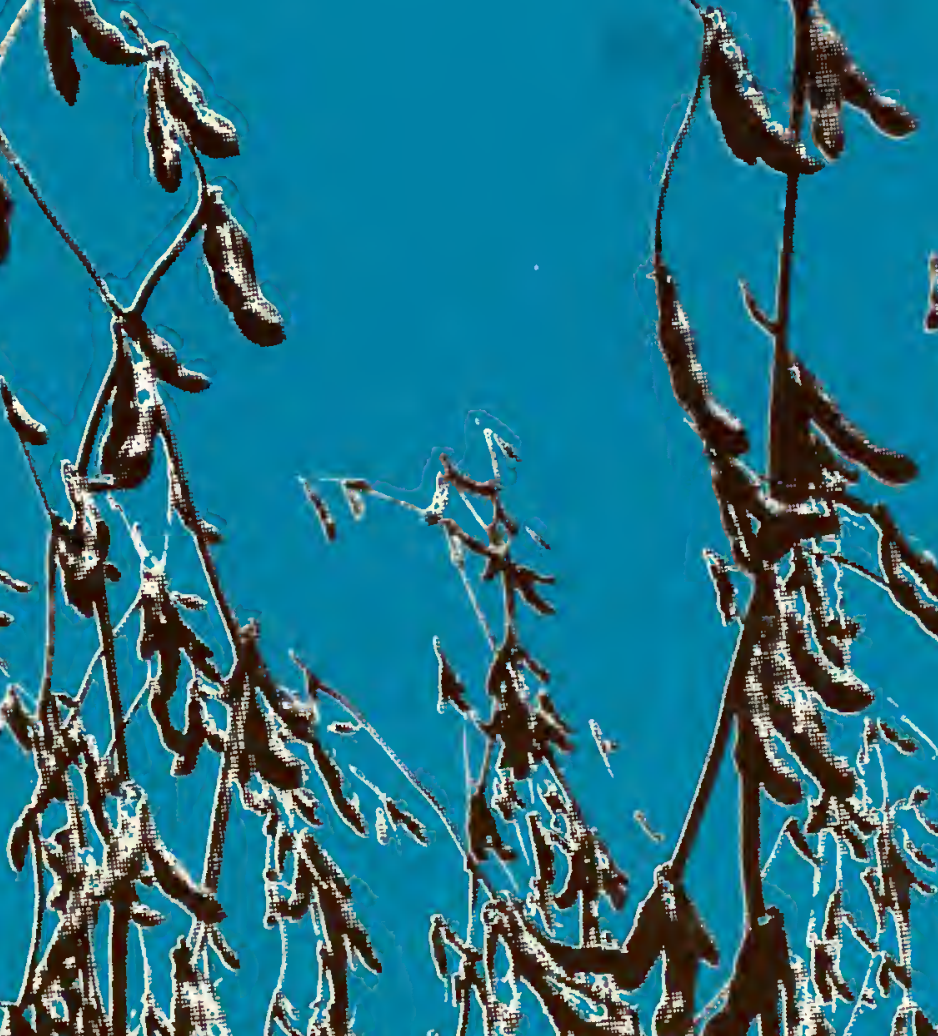

i

A. (1)

Mn.

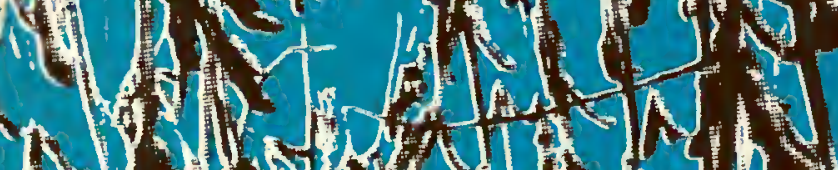

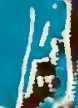

167 I A) 40.90 m.

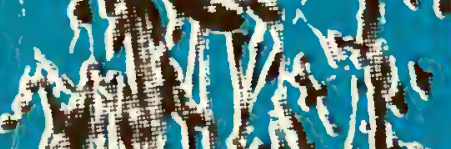

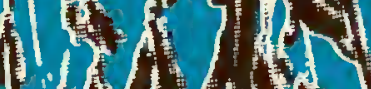
at.

(x) Non

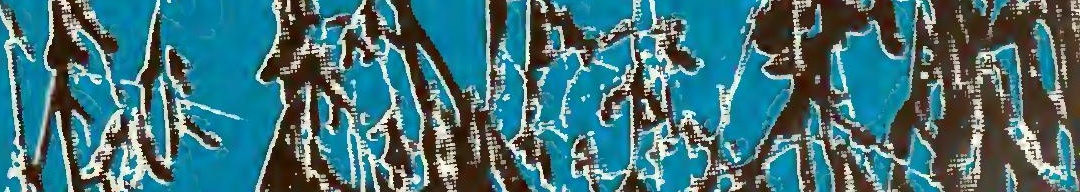
M 1 (1)

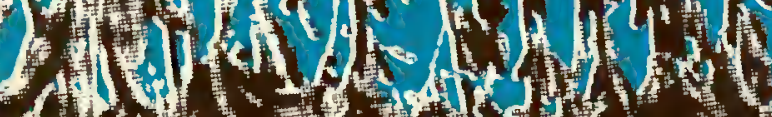

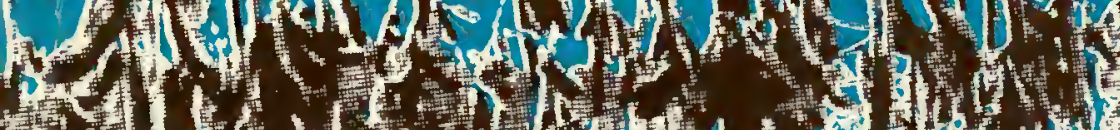

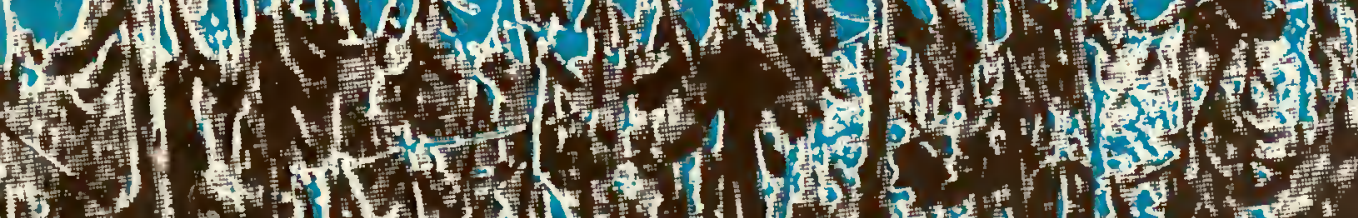

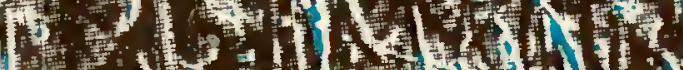
t 10 . 


\begin{abstract}
The marketing of soybeans in the U.S. involves complex interregional grain movements. Moving the crop from the area of concentrated production to points where it is used or exported requires a large transportation capacity. To provide a basis for policy and investment decisions, detailed information on soybean movements during 1977 was collected from 3,500 grain merchandising, processing, and exporting firms in 41 states. Survey data on receipts and shipments for each state or substate area were expanded to represent total volumes for those areas and were verified by comparison with information from secondary sources. The data, which represent the most comprehensive and accurate information available on soybean movements, are presented and summarized in this bulletin.
\end{abstract}

Keywords: Grain flows, grain shipping, grain transportation, interregional analysis, soybeans, soybean marketing 


\section{Soybean Movements}

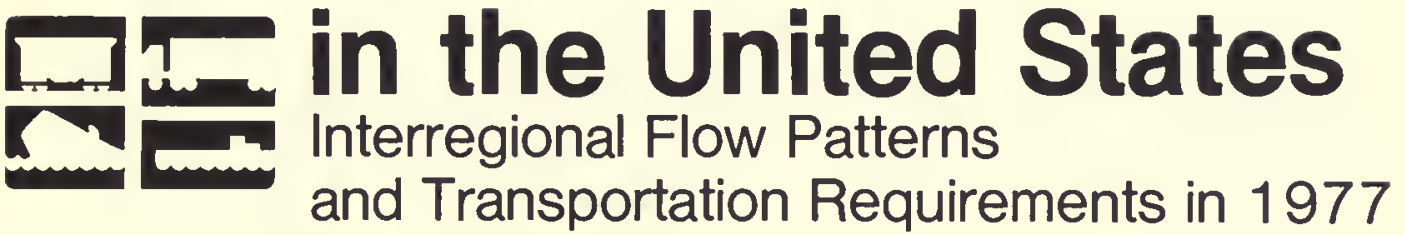

Mack N. Leath, Agricultural Economist, Economics and Statistics Service, U. S. Department of Agriculture

Lowell D. Hill, L. J. Norton Professor of Marketing, Department of Agricultural Economics, University of Illinois at Urbana-Champaign

Stephen W. Fuller, Associate Professor, Department of Agricultural Economics, Texas A\&M University

North Central Regional Research Publication No. 273

Southern Cooperative Series Bulletin 251

Illinois Bulletin 766
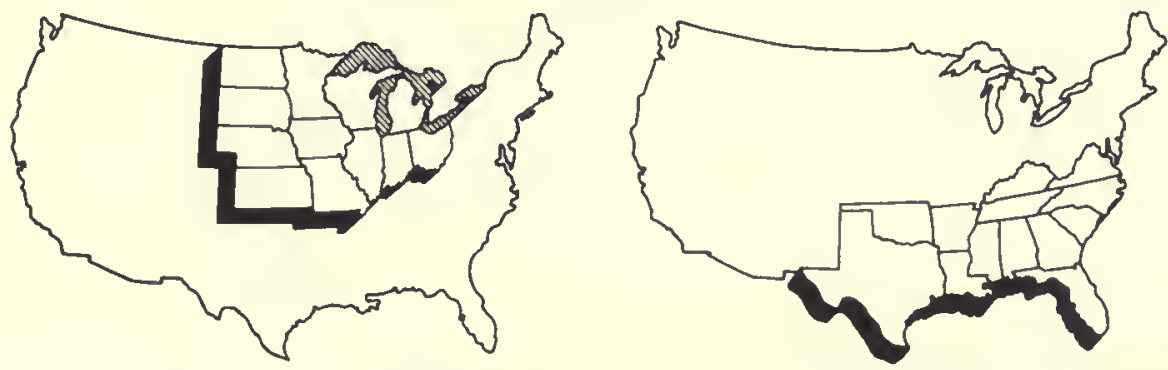

Agricultural Experiment Stations of Alabama, Arkansas, California, Georgia, Idaho, Illinois, Indiana, lowa, Kansas, Kentucky, Louisiana, Michigan, Minnesota, Mississippi, Missouri, Montana, Nebraska, North Dakota, Ohio, Oklahoma, Oregon, South Dakota, Tennessee, Texas, Wisconsin, and the United States Department of Agriculture cooperating.

The participating agricultural experiment stations and government agencies provide equal opportunities in programs and employment.

January 1981 
This publication is sponsored by the Agricultural Experiment Stations of the following states, by the Science and Education Administration - Cooperative Research (SEA-CR), U.S. Department of Agriculture (USDA), and by the Economics and Statistics Service (ESS), USDA.

\begin{tabular}{|c|c|}
\hline $\begin{array}{c}\text { Participating } \\
\text { state }\end{array}$ & $\begin{array}{c}\text { Experiment station } \\
\text { director }\end{array}$ \\
\hline Alabama & G. A. Buchanan \\
\hline Arkansas & L. O. Warren \\
\hline California & J. B. Kendrick, Jr. \\
\hline Georgia & W. P. Flatt \\
\hline Idaho & R. J. Miller \\
\hline Illinois & R. G. Cragle \\
\hline Indiana & B. R. Baumgardt \\
\hline lowa & L. R. Kolmer \\
\hline Kansas & F. W. Smith \\
\hline Kentucky & C. E. Barnhart \\
\hline Louisiana & D. Chambers \\
\hline Michigan & S. H. Wittwer \\
\hline Minnesota & R. J. Sa uer \\
\hline Mississippi & R. R. Foil \\
\hline Missouri & A. M. Lennon \\
\hline Montana & J. R. Welsh \\
\hline Nebraska & R. G. Amold \\
\hline North Dakota & H. R. Lund \\
\hline Ohio & R. M. Kottman \\
\hline Oklahoma & C. B. Browning \\
\hline Oregon & J. R. Davis \\
\hline South Dakota & R. A. Moore \\
\hline Tennessee & D. M. Gossett \\
\hline Texas & N. P. Clarke \\
\hline Wisconsin & L. M. Walsh \\
\hline
\end{tabular}

This publication reports the results of research conducted by three regional technical committees: Southern Regional Committee S-115 on Alternative Structures for Increasing Efficiency in Intra- and Inter-regional Grain Marketing Systems; North Central Regional Committee NC-137 on Evaluation of Alternative Rural Freight Transportation, Storage, and Distribution Systems, and North Central Regional Committee NC-139 on Economic Analysis of the U.S. Grain Exporting System. The following state Agricultural Experiment Station representatives, Tennessee Valley Authority (TVA) staff members, and U.S. Department of Agriculture personnel comprised the technical committees.

\section{SOUTHERN REGIONAL COMMITTEE S-115}

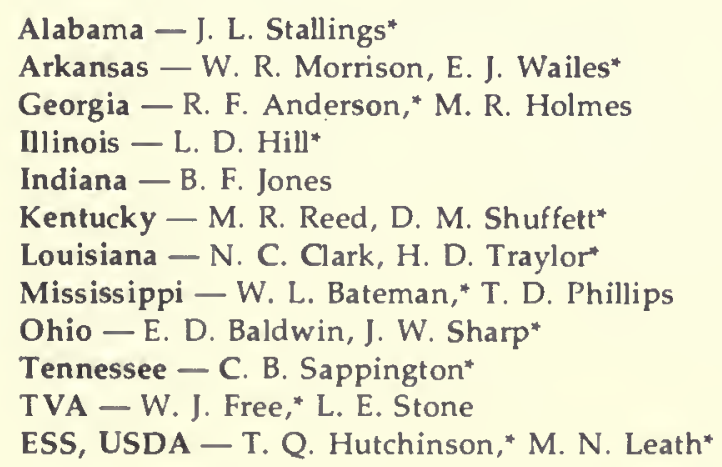

SEA - CR, USDA - L. C. Halvorson

Administrative Adviser - T. J. Whatley (Tennessee)

\section{NORTH CENTRAL REGIONAL COMMITTEE NC-137}

Illinois - L. D. Hill*

Indiana $-J$. K. Binkley*

Iowa - C. P. Baumel*

Kansas - L. O. Sorenson*

Michigan - S. R. Thompson*

Minnesota - R. P. Dahl*

Missouri - R. K. Rudel ${ }^{*}$

Montana - W. W. Koo*

Nebraska - D. G. Anderson*

North Dakota - D. W. Cobia*

Ohio - D. W. Larson*

Oklahoma - M. A. Johnson, R. L. Oehrtman*

South Dakota - C. E. Lamberton*

Texas - S. W. Fuller*

Wisconsin - R. H. Vilstrup*

ESS, USDA - L. A. Hoffman,* L. D. Schnake, D. L. Watt

SEA - CR, USDA - L. C. Halvorson

Administrative Adviser - D. E. Anderson (North Dakota)

\section{NORTH CENTRAL REGIONAL COMMITTEE NC-139}

California - A. F. McCalla*

Idaho - J. R. Jones*

Illinois - L. D. Hill*

Indiana - B. F. Jones*

lowa - G. W. Ladd*

Kansas - L. W. Schruben*

Minnesota - R. P. Dah"*

Missouri - R. K. Rudel*

Montana - G. L. Cramer*

Nebraska - D. A. Linsenmeyer*

North Dakota - D. E. Anderson, W. W. Wilson*

Ohio - J. W. Sharp*

Oklahoma - R. L. Oehrtman*

Oregon - M. V. Martin*

South Dakota - A. C. Sogn

Texas - M. L. Cook*

ESS, USDA - A. R. Bunker, * R. E. Friend," C. B. Hanrahan,* B. H. Wright*

Federal Grain Inspection Service, USDA - F. F. Niernberger

SEA - CR, USDA - L. C. Halvorson

Administrative Adviser - H. J. Schweitzer (1llinois)

The following state Agricultural Experiment Station personnel also cooperated in the research:
Arizona - T. F. Archer

Colorado - W. T. Spencer

Connecticut - S. K. Seaver

Florida - J. K. Dow

Maine - D. D. Harlan

Maryland - J. L. Crothers

New York - M. E. Brunk

North Carolina - T. E. Nichols
Pennsylvania - S. K. Abshire H. L. Moore

South Carolina - S. E. Miller Utah - R. H. Anderson Vermont - N. T. Power Virginia - D. E. Kenyon Washington - K. L. Casavant Wyoming - J. S. St. Clair
- Voting member and project leader for the participating organization. 


\section{Preface}

The research reported in this bulletin is the first effort ever made to survey grain shippers and receivers nationwide; it is the most comprehensive study of grain movements ever conducted. Members of the technical committees, including representatives of Agricultural Experiment Stations in 25 states, assisted in conducting an industry survey to collect flow data for wheat, corn, soybeans, sorghum, oats, barley, and rye. In addition, surveys were conducted in 16 other states through contracts with 15 universities located in those states. The industry surveys were coordinated by Lowell D. Hill, Department of Agricultural Economics, University of Illinois at Urbana-Champaign. The data were tabulated and summarized under the supervision of Mack N. Leath, Economics and Statistics Service, U.S. Department of Agriculture. The success of this research project is due to the cooperation of thousands of grain marketing firms and the efforts of researchers in the many participating states.

The research was funded in part through contract DACW 72-78-C-0005 with the Institute of Water Resources, U.S. Army Corps of Engineers. Supplemental support was provided by the Federal Railroad Administration of the U.S. Department of Transportation, the Maritime Administration of the U.S. Department of Commerce, and the St. Lawrence Seaway Development Corporation. Administration of grant funds was coordinated by Lowell D. Hill, University of Illinois at Urbana-Champaign.

\section{Contents}

Introduction $\ldots \ldots \ldots \ldots \ldots \ldots \ldots \ldots \ldots \ldots \ldots \ldots \ldots \ldots$

Purpose of Study $\ldots \ldots \ldots \ldots \ldots \ldots \ldots \ldots \ldots \ldots \ldots \ldots \ldots \ldots \ldots \ldots \ldots \ldots \ldots$

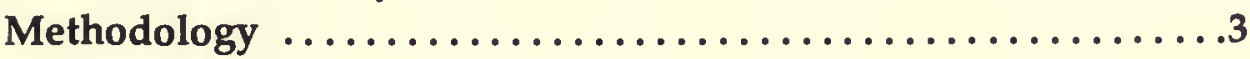

Verification of Data $\ldots \ldots \ldots \ldots \ldots \ldots \ldots \ldots \ldots \ldots$

Overview of Movements .........................10

Receipts and Shipments by Area $\ldots \ldots \ldots \ldots \ldots \ldots \ldots \ldots$ 



\section{Tables}

1. Soybean Supply and Distribution in the United States for Marketing

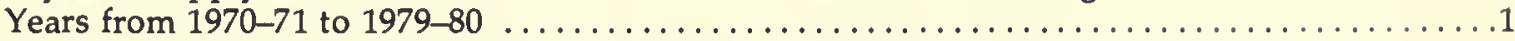

2. Production, Farm Use, and Sales of Soybeans by State for the 1977 Crop .............

3. Export Regions, Port Areas, and the Ports Included in Each Area . . . . . . . . . . . . . . 5

4. Comparison of 1977 Soybean Receipts, Shipments, and Inspections for Export at Various Port Areas . . . . . . . . . . . . . . . . . . . . . . . . . 6

5. Comparison of 1977 Waterway Movements of Soybeans in the U.S. as Reported by Survey Respondents and the U.S. Army Corps of Engineers . . . . . . . . . . . . . . 7

6. Comparison of 1977 Rail Movements of Soybeans as Reported by Survey Respondents and as Estimated from the 1 Percent Waybill Sample in Selected States ............... 8

7. 1977 Intrastate Shipments of Soybeans for Each State and Mode of Transportation . . . . . . . 12

8. 1977 Interstate Shipments of Soybeans for Each State and Mode of Transportation .........13

9. 1977 Interstate Receipts of Soybeans for Each State and Mode of Transportation . . . . . . . . .14

10. 1977 Movements of Soybeans to Points of Export for Each Originating State

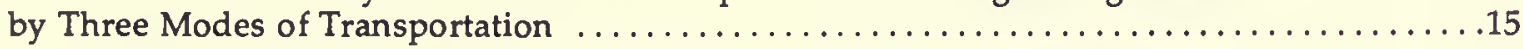

11. 1977 Receipts of Soybeans at Port Areas by Each Mode of Transportation . . . . . . . . . . . 17

12. 1977 Exports of U.S. Soybeans from Canada and the United States

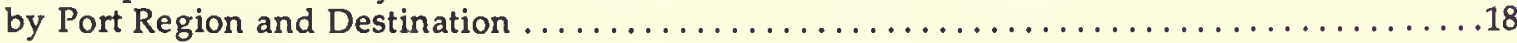

$13-$

88. 1977 Soybean Receipts and Shipments by State and Substate Areas . . . . . . . . . . .20 $89-$

110. 1977 Soybean Receipts and Shipments by Port Areas.........................54

\section{Figures}

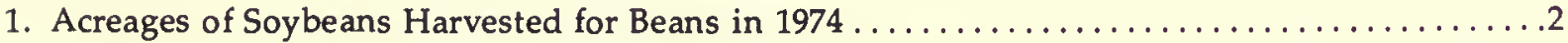

2. Location of Grain Flow Study Regions .................................

3. Patterns of Soybean Flows to Domestic Destinations in $1977 \ldots \ldots \ldots \ldots \ldots \ldots \ldots \ldots \ldots \ldots$

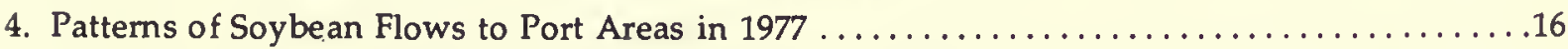

5. Proportion of 1977 Soybean Movements to Export Regions from Each Originating State . . . . 16 



\title{
Soybean Movements in the United States
}

\author{
Interregional Flow Patterns and Transportation Requirements in 1977
}

\section{INTRODUCTION}

Information about the origin and destination of grain produced in the United States and about the modes of transportation used to convey it is important for many policy and investment decisions. Although data on the quantities of grains shipped abroad from each port are available and statistics on the amount of grain shipped on the inland waterways are published annually, little information has been available that could be used to match origins with destinations and to identify the mode of transportation used.

Through personal interviews with over 3,500 grain merchandisers, processors, and exporters throughout the United States, data on origins, destinations, and transport modes have now been assembled for corn, wheat, soybeans, sorghum, oats, barley, and rye. This publication summarizes the data for soybeans. Other publications in this series provide similar information for the other grains.
Soybeans are the most important oilseed crop produced in the United States. In the 1970s annual production expanded every year except two and doubled during that decade, increasing from 1,127 million bushels in 1970 to 2,268 million bushels in 1979 (Table 1). The volume of soybeans produced exceeded total wheat production in both 1978 and 1979. Currently soybeans rank second among major field crops in terms of annual volume produced, exceeded only by corn.

The major domestic use of soybeans is the production of soybean meal and oil. Soybean processors crushed over one billion bushels in 1978-79, a record for the U.S. (Table 1). During calendar year 1977, they crushed 971 million bushels. The volume crushed varies from year to year, depending upon the availability of beans and the demands for meal and oil.

The amount used for seed is almost totally a function of the acreage planted. The increase in that quantity during the late 1970 s reflects the rapid expansion in soybean acreage. In 1979 a record 71.6

Table 1. Soybean Supply and Distrlbution In the Unlted States for Marketing Years from 1970-71 to 1979-80

\begin{tabular}{|c|c|c|c|c|c|c|c|c|c|}
\hline \multirow[b]{2}{*}{$\begin{array}{l}\text { Marketing } \\
\text { year }^{a}\end{array}$} & \multicolumn{3}{|c|}{ Supply } & \multicolumn{6}{|c|}{ Disappearance } \\
\hline & $\begin{array}{l}\text { Begin- } \\
\text { ning } \\
\text { stocks }\end{array}$ & $\begin{array}{l}\text { Produc- } \\
\text { tion }\end{array}$ & Total & $\begin{array}{l}\text { Crush- } \\
\text { ing }\end{array}$ & Seed & Feed & Residual & $\begin{array}{c}\text { Net } \\
\text { exports }^{b}\end{array}$ & Total \\
\hline & \multicolumn{9}{|c|}{ millions of bushels } \\
\hline $1970-71$ & 230 & 1,127 & 1,357 & 760 & 48 & 1 & 15 & 434 & 1,258 \\
\hline $1971-72$ & 99 & 1,176 & 1,275 & 721 & 51 & 1 & 13 & 417 & 1,203 \\
\hline $1972-73$ & 72 & 1,271 & 1,343 & 722 & 61 & 1 & 20 & 479 & 1,283 \\
\hline $1973-74$ & 60 & 1,547 & 1,607 & 821 & 56 & 1 & 19 & 539 & 1,436 \\
\hline $1974-75$ & 171 & 1,216 & 1,387 & 701 & 57 & 1 & 22 & 421 & 1,202 \\
\hline $1975-76$ & 185 & 1,547 & 1,732 & 865 & 54 & 1 & 13 & 555 & 1,488 \\
\hline $1976-77$ & 245 & 1,288 & 1,533 & 790 & 62 & 0 & 14 & 564 & 1,430 \\
\hline $1977-78$ & 103 & 1,762 & 1,865 & 927 & 69 & 0 & 7 & 701 & 1,704 \\
\hline $1978-79$ & 161 & 1,870 & 2,031 & 1,018 & 76 & 0 & 10 & 753 & 1,857 \\
\hline $1979-80^{c}$ & 174 & 2,268 & 2,442 & 1,130 & 80 & 0 & 17 & 850 & 2,077 \\
\hline
\end{tabular}

Source: Fats and Oils Situation, Economics and Statistics Service, U.S. Department of Agriculture, FOS-300 (July, 1980 ), p. 6.

a Beginning September 1.

"The volume imported was negligible.

'Preliminary data. 
million acres were planted to soybeans, and seed usage jumped to a new peak of 76 million bushels during the 1978-79 marketing year.

The volume exported, which increased every year except two during the 1970s, has consistently amounted to between 35 and 40 percent of the total annual disappearance. Export shipments of soybeans increased from 417 million bushels in 197172 to an estimated 850 million bushels in 1979-80. During calendar year 1977, 593 million bushels were exported.

The volume of soybeans that must be transported is large because the crop is grown in a highly concentrated production area and because the very large export volume is channeled primarily through one export region comprising the ports on the Gulf of Mexico. Soybean production is confined almost entirely to the eastern half of the country (Figure 1) where summer rainfall is adequate. Production is concentrated in the Corn Belt region (Ohio, Indiana, Illinois, Iowa, Missouri, and Minnesota) and the Mississippi River Delta region (Tennessee, Mississippi, Arkansas, and Louisiana). The Corn Belt region produced about 65 percent of the total U.S. soybean crop in 1977, and the Delta region produced about 17 percent (Table 2).

\section{PURPOSE OF STUDY}

Analysis of grain flow patterns can reveal the geographical nature of grain markets and the types of transportation services required by the grain industry. This in formation is useful to grain firms in identifying additional marketing opportunities and in making decisions about where to locate new handling, storage, and processing facilities.

Of equal importance is the value of this information to those who set federal and state transportation policies. The formulation of rational grain transportation policies depends upon knowledge of existing grain flows and associated transportation modes. In many situations, firms or public agencies make decisions affecting the production, storage, and transportation of grain without adequate information about grain distribution patterns and the demands that those decisions will place on the various transportation modes. The objectives of this study were:

1. To determine the volume of soybeans moving between various origins and destinations

2. To determine the extent to which the various transportation modes are employed in the movement of soybeans in the U.S.

Figure 1. Acreages of soybeans harvested for beans in 1974.

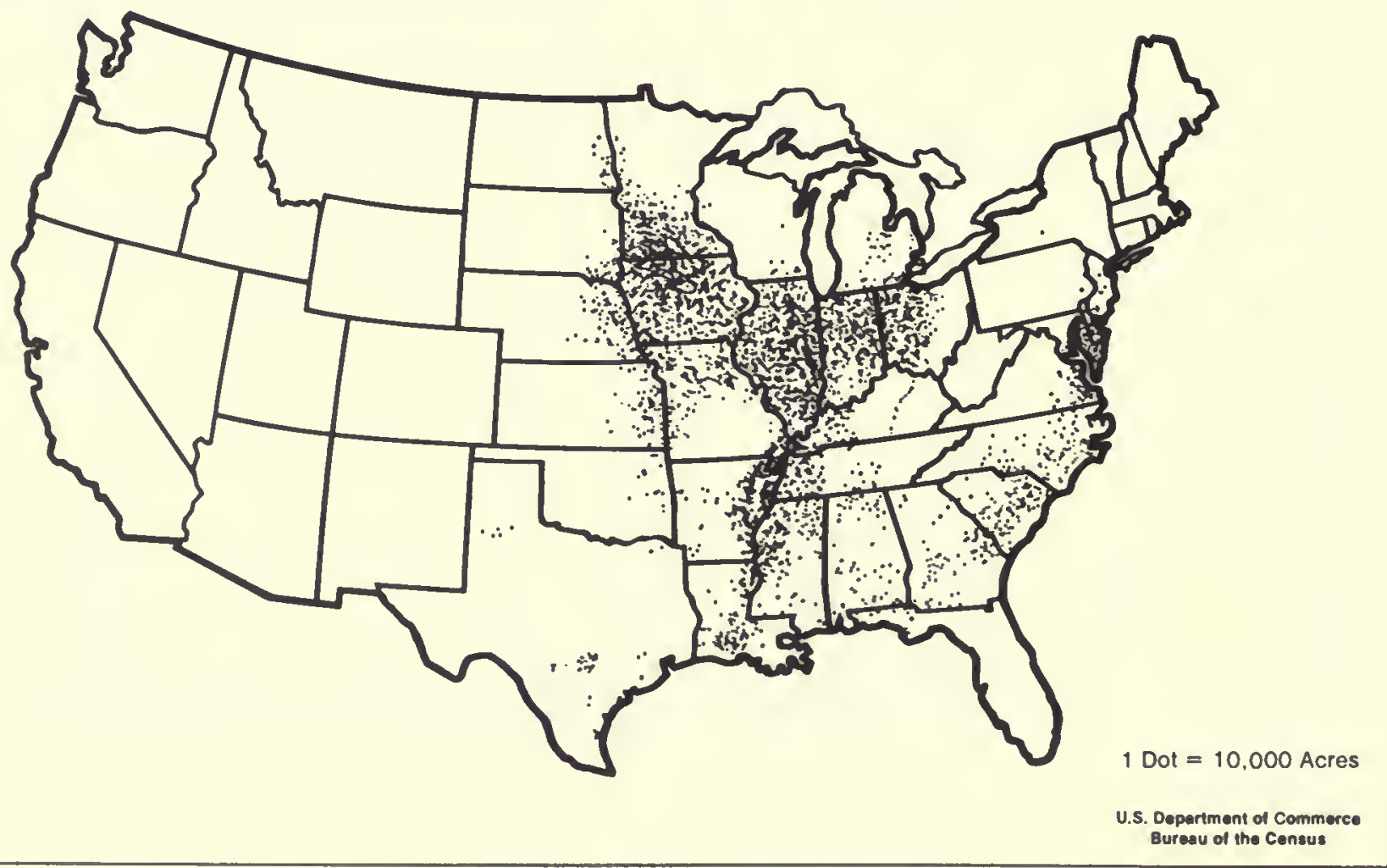




\section{METHODOLOGY}

For the purposes of this study, the United States was divided into 132 numbered regions and 31 ports, as shown in Figure 2. Data for the 31 ports were aggregated into 13 port areas located in four major export regions. The specific ports included in each port area are listed with their identifying numbers in Table 3.

Soybean flow data were collected for the 1977 calendar year primarily through personal interviews with representatives of grain handling, storage, and processing firms in 41 states. The firms from which data were obtained included country elevators, inland terminal elevators, river terminal elevators, feed manufacturers, export elevators, commercial feedlots, and processors. A representative from each state's Agricultural Experiment Station was responsible for drawing the sample and conducting the interviews.

The sampling of inland grain elevators in the particular state was carried out by listing the elevators in descending order of storage capacity. Starting with the largest, elevators were added to the sample until the total of their storage capacities was equal to at least 25 percent of the inland elevator storage capacity in that state. Not less than 10 percent of the remaining elevators were then selected at random. For river elevators the procedure was simpler: a minimum of 50 percent of the elevators were selected by random sampling.

Feed manufacturing firms in each state were arrayed on the basis of their production capacity. Starting with the largest, feed firms on the list were added to the sample until the total of their production capacities equalled or exceeded 10 percent of the total feed manufacturing capacity in the state. Ten percent or more of the remaining firms were then selected at random and included in the sample. All exporters and processors were included in the interviews.* Data based on random samples were expanded in proportion to the sampling rate to convert the data into estimates for the entire region or state.

The same types of information were gathered from all of the grain handlers and processors interviewed. Each firm was asked to identify the volume of soybeans that it received from each region and the volume received by each mode of transportation. The firms were also asked to identify each region or port area for which their shipments were destined and the quantity shipped by each mode.

\footnotetext{
* Only one major processor did not provide data for the study. Data on receipts by that firm were estimated from information furnished by shippers.
}

Agricultural Experiment Station representatives verified the accuracy of the data collected, expanded the sample data to state totals, and delivered the summary data for each grain and for every substate region to the U.S. Department of Agriculture for processing. As receivers' and shippers' data were tabulated, the Experiment Station representative in each state checked any discrepancies to identify potential data errors and to arrive at a single number for each origin-destination pair. Insofar as possible, the state representatives checked the data for each shipment to ascertain that they were consistent and logical.

Table 2. Production, Farm Use, and Sales of Soybeans by State for the 1977 Crop

State Production $\begin{gathered}\text { Used on } \\ \text { farms } \\ \text { where } \\ \text { produced }\end{gathered} \quad$ Sales

\begin{tabular}{|c|c|c|c|}
\hline \multirow[b]{2}{*}{ Alabama ......... } & \multicolumn{3}{|c|}{ thousands of bushels } \\
\hline & 33,600 & 302 & 33,298 \\
\hline Arkansas & 105,800 & 2,010 & 103,790 \\
\hline Delaware ........ & 5,400 & 151 & 5,249 \\
\hline Florida $\ldots \ldots \ldots$ & 8,175 & 65 & 8,110 \\
\hline Georgia ........ & 21,800 & 676 & 21,124 \\
\hline Illinois . . & 336,300 & 3,027 & 333,273 \\
\hline Indiana & 144,300 & 1,732 & 142,568 \\
\hline lowa. & 251,340 & 2,765 & 248,575 \\
\hline Kansas & 28,215 & 705 & 27,510 \\
\hline Kentucky ........ & 40,920 & 532 & 40,388 \\
\hline Louisiana ... & 62,980 & 252 & 62,728 \\
\hline Maryland & 8,775 & 272 & 8,503 \\
\hline Michigan & 21,600 & 562 & 21,038 \\
\hline Minnesota ....... & 133,835 & 2,275 & 131,560 \\
\hline Mississippi . . . & 78,475 & 1,099 & 77,376 \\
\hline Missouri ......... & 148,800 & 2,381 & 146,419 \\
\hline Nebraska & 40,680 & 895 & 39,785 \\
\hline New Jersey ....... & 4,248 & 102 & 4,146 \\
\hline New York........ & 437 & 37 & 400 \\
\hline North Carolina ... & 29,040 & 668 & 28,372 \\
\hline North Dakota & 3,500 & 98 & 3,402 \\
\hline$\ldots \ldots \ldots$ & 119,990 & 1,800 & 118,190 \\
\hline Oklahoma & 7,820 & 242 & 7,578 \\
\hline Pennsylvania.... & 2,077 & 98 & 1,979 \\
\hline South Carolina... & 26,650 & 799 & 25,851 \\
\hline South Dakota .... & 9,608 & 269 & 9,339 \\
\hline Tennessee ........ & 52,170 & 991 & 51,179 \\
\hline Texas .......... & 20,140 & 60 & 20,080 \\
\hline Virginia & 8,360 & 293 & 8,067 \\
\hline Wisconsin ...... & 6,720 & 269 & 6,451 \\
\hline U.S. total & $\overline{1,761,755}$ & $\overline{25,427}$ & $1,736,328$ \\
\hline
\end{tabular}

Source: Field Crops: Production, Disposition, Value, 1977-1978, Economics and Statistics Service, U.S. Department of Agriculture, CrPr 1 (79) (April 11, 1979), p. 13. 


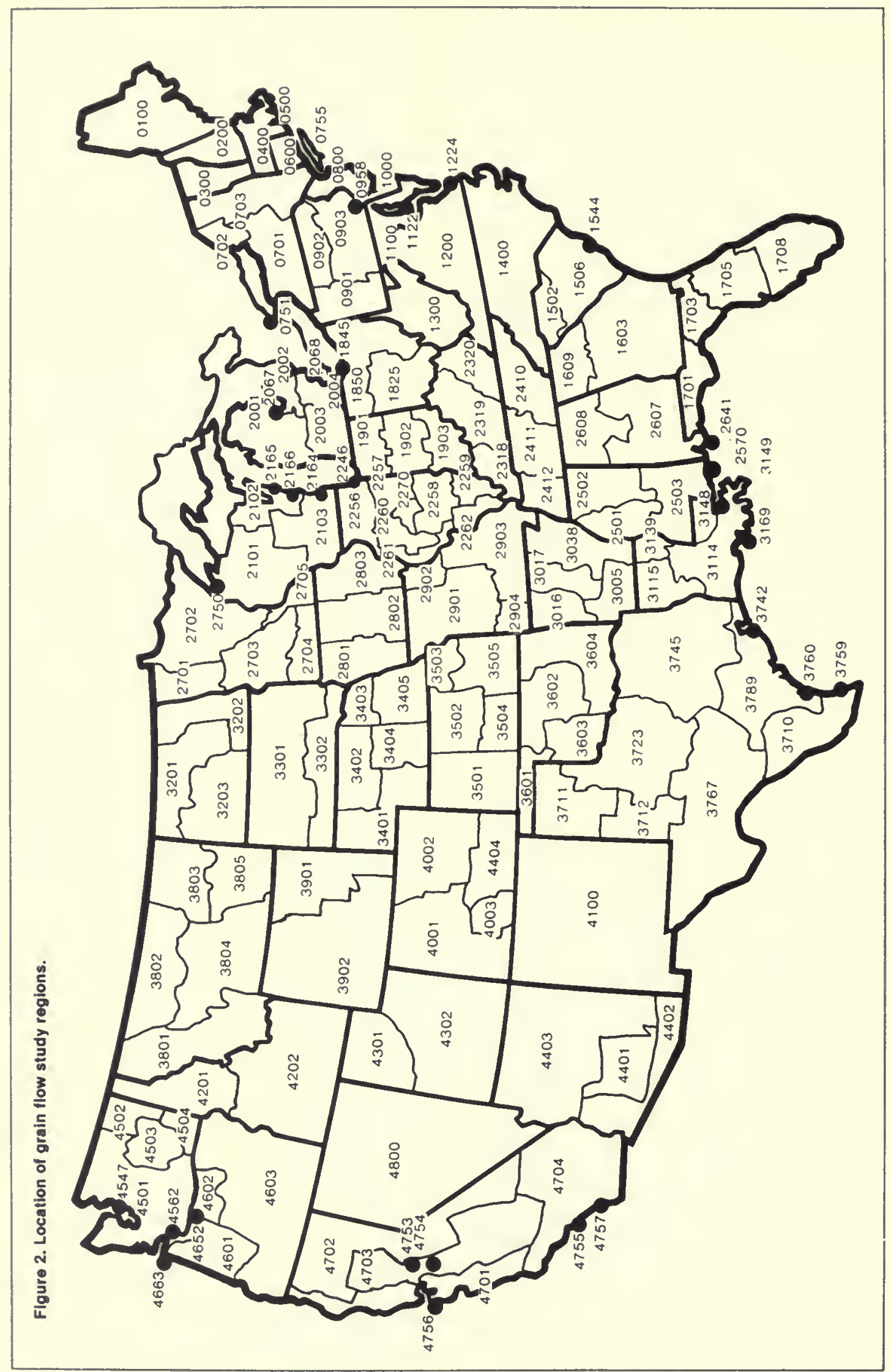


Table 3. Export Regions, Port Areas, and the Ports Included in Each Area

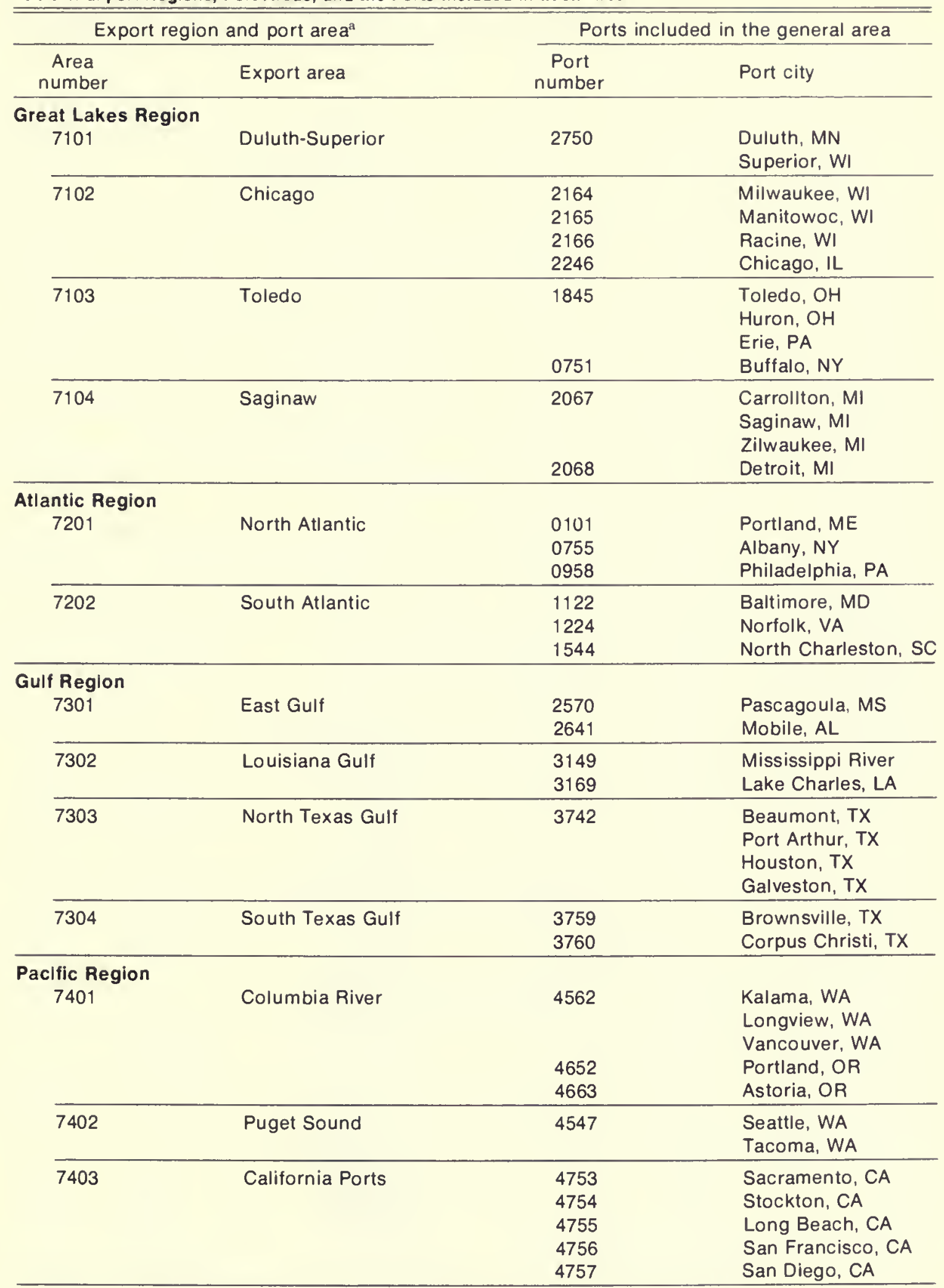

a These port areas will be used in this report to avoid disclosure of data from individual firms. 


\section{VERIFICATION OF DATA}

The accuracy of the data on the volume of soybeans shipped between the various origins and destinations by each mode of transportation was verified by several direct and indirect comparisons with data from other sources. One indirect check was made by totaling interstate shipments and subtracting from that value the total of interstate receipts for each state to determine how closely the results agreed with the surplus or deficit calculated for the state. Exact correspondence was not expected since the quantities used for seed and crushed by processors were estimated rather than determined from actual consumption data. Any major discrepancies, however, were investigated to verify that they did not indicate significant errors in the survey data.

A second check on total volume was made by comparing total receipts at each port with official data on inspections for export as published by the Market News Service of the U.S. Department of Agriculture (Table 4). Because there were few opportunities for either set of data to miss significant volumes, these numbers compared very closely. Discrepancies between receipts and exports at some of the port areas were explained by shipments to domestic destinations from export elevators, shipments to processing plants located in the port area, and changes in inventory between the beginning and end of the year.

Supplemental information about grain shipments on inland waterways was provided by the U.S. Army Corps of Engineers. Since these data were based on the actual bill of lading for each shipment, they were, in principle, a complete census of all barge shipments. As Table 5 shows, the survey data and the Corps of Engineers data on state-to-state shipments on inland waterways correspond closely. Differences between the two sets of data can be explained by (1) a significant number of shipments for which the origins and destinations are noted as "unknown" in the Corps data, (2) changes in the destination of a barge after it left the loading dock, (3) incomplete reporting of loadings to the Corps of Engineers, and (4) errors in reporting by survey respondents. Substantial differences were found in the two sets of data on the volume moving by barge from several states. These differences could not be resolved.

The last method of validation provides important insight into U.S. Department of Transportation data

\footnotetext{
- The surplus or deficit for each state was calculated by adding the 1977 production to the stocks in all positions as of January 1, 1977 , then subtracting the estimated amount used for livestock feed, processing, and seed and deducting the stocks in all positions as of January 1, 1978.
}

based on a 1 percent sample of all rail bills of lading. These data were expanded to develop estimates of annual shipments and receipts in each state and then compared with the rail shipments reported by survey respondents (Table 6). Some similarities are apparent, but there are also many major differences. These discrepancies appear to be greatest for cases where unit trains account for a large share of the shipments between states, and they appear to be smallest where single-car shipments predominate. Additional analysis of both data sets led to the conclusion that there are serious sampling errors in the 1 percent waybill statistics and that those data should therefore be used with caution, expecially where soybeans commonly move in multiple-car units. In Ohio and Indiana, intrastate movements to the Atlantic ports were seriously understated in the 1 percent waybill sample.

The comparisons between various data sources increase the confidence in the accuracy of estimates

Table 4. Comparison of 1977 Soybean Recelpts, Shlpments, and Inspectlons for Export at Varlous Port Areas

\begin{tabular}{|c|c|c|c|}
\hline \multirow{2}{*}{$\begin{array}{l}\text { Port } \\
\text { are } \mathrm{a}^{a}\end{array}$} & \multicolumn{2}{|c|}{$\begin{array}{l}\text { Quantities deter- } \\
\text { mined by survey }\end{array}$} & \multirow{2}{*}{$\begin{array}{l}\text { Inspec- } \\
\text { tions fo } \\
\text { export }\end{array}$} \\
\hline & Receipts & Exports & \\
\hline
\end{tabular}

thousands of bushe/s

\section{GREAT LAKES REGION}

Duluth-Superior .....

Chicago ............

Toledo .............

Saginaw ............

Subtotal ...........

$\begin{array}{rrr}0 & 0 & 0 \\ 29,491 & 15,866 & 14,187 \\ 46,795 & 47,088 & 47,088 \\ 1,148 & 1,148 & \frac{1,317}{62,592}\end{array}$

\section{ATLANTIC REGION}

North Atlantic .......

14,140

13,802

12,287

South Atlantic ........

Subtotal ...........

56,782

53,996

67,798

53,218

65,505

\section{GULF REGION}

East Gulf...........

Louisiana Gulf ......

North Texas Gulf ....

71,122

68,325

68,225

387,502

368,153

368,153

South Texas Gulf ....

Subtotal ..........

27,491

27,450

27,447

$\frac{0}{486,115}$

463,928

463,825

\section{PACIFIC REGION}

Columbia River ......

Puget Sound .........

California ...........

Subtotal

\begin{tabular}{rrr}
565 & 565 & 605 \\
443 & 443 & 17 \\
295 & 295 & 295 \\
\cline { 3 - 3 } \cline { 3 - 3 } 1,303 & 1,303 & 917 \\
635,774 & 597,131 & 592,839 \\
\hline
\end{tabular}

Total

635,774

\section{.}

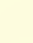


Tabie 5. Comparison of 1977 Waterway Movements of Soybeans in the U.S. as Reported by Survey Respondents and the U.S. Army Corps of Engineers

\begin{tabular}{cccc}
\hline \hline $\begin{array}{c}\text { Originating } \\
\text { state }\end{array}$ & $\begin{array}{c}\text { Destination } \\
\text { state }\end{array}$ & Survey & Corps of \\
Engineers data
\end{tabular}

\begin{tabular}{|c|c|c|c|}
\hline \multirow[t]{2}{*}{ Alabama and Tennessee } & \multirow[t]{2}{*}{$\begin{array}{l}\text { Alabama and Tennessee } \\
\text { Louisiana and Mississippi } \\
\text { Subtotal }\end{array}$} & $\begin{array}{l}10,719 \\
18,603 \\
\end{array}$ & $\begin{array}{l}13,801 \\
21,311 \\
\end{array}$ \\
\hline & & 29,322 & 35,112 \\
\hline Arkansas & Louisiana and Mississippi & 38,586 & 15,455 \\
\hline \multirow[t]{2}{*}{ Florida } & $\begin{array}{l}\text { Alabama and Tennessee } \\
\text { Louisiana and Mississippi }\end{array}$ & $\begin{array}{r}1,616 \\
813 \\
\end{array}$ & $\begin{array}{r}2,633 \\
1,165 \\
\end{array}$ \\
\hline & Subtotal & 2,429 & 3,798 \\
\hline Illinois & $\begin{array}{l}\text { Alabama and Tennessee } \\
\text { Arkansas } \\
\text { Illinois } \\
\text { Louisiana and Mississippi } \\
\text { Subtotal }\end{array}$ & $\begin{array}{r}10,649 \\
4,000 \\
1,321 \\
109,109 \\
125,079\end{array}$ & $\begin{array}{r}7,480 \\
97 \\
1,717 \\
100,852 \\
110,146\end{array}$ \\
\hline \multirow[t]{2}{*}{ Indiana } & $\begin{array}{l}\text { Alabama and Tennessee } \\
\text { Louisiana and Mississippi }\end{array}$ & $\begin{array}{r}562 \\
8,033 \\
\end{array}$ & $\begin{array}{r}219 \\
9,202 \\
\end{array}$ \\
\hline & Subtotal & 8,595 & 9,421 \\
\hline \multirow[t]{2}{*}{ lowa } & $\begin{array}{l}\text { Alabama and Tennessee } \\
\text { Illinois } \\
\text { Lo uisiana and Mississippi }\end{array}$ & $\begin{array}{r}692 \\
0 \\
29,615 \\
\end{array}$ & $\begin{array}{r}1,720 \\
134 \\
31,700 \\
\end{array}$ \\
\hline & Subtotal & 30,307 & 33,554 \\
\hline \multirow[t]{2}{*}{ Kansas and Nebraska } & $\begin{array}{l}\text { Alabama and Tennessee } \\
\text { Louisiana and Mississippi }\end{array}$ & $\begin{array}{r}0 \\
1,878 \\
\end{array}$ & $\begin{array}{r}35 \\
1,419 \\
\end{array}$ \\
\hline & Subtotal & 1,878 & 1,454 \\
\hline \multirow[t]{2}{*}{ Kentucky } & $\begin{array}{l}\text { Alabama and Tennessee } \\
\text { Louisiana and Mississippi }\end{array}$ & $\begin{array}{r}287 \\
11,393 \\
\end{array}$ & $\begin{array}{r}618 \\
8,376 \\
\end{array}$ \\
\hline & Subtotal & 11,680 & 8,994 \\
\hline \multirow[t]{2}{*}{ Louisiana and Mississippi } & $\begin{array}{l}\text { Louisiana and Mississippi } \\
\text { Other states }\end{array}$ & $\begin{array}{r}71,814 \\
0 \\
\end{array}$ & $\begin{array}{r}54,801 \\
5,095 \\
\end{array}$ \\
\hline & Subtotal & 71,814 & 59,896 \\
\hline \multirow[t]{2}{*}{ Minnesota and Wisconsin } & $\begin{array}{l}\text { Louisiana and Mississippi } \\
\text { Other states }\end{array}$ & $\begin{array}{r}25,940 \\
0 \\
\end{array}$ & $\begin{array}{r}23,689 \\
743 \\
\end{array}$ \\
\hline & Subtotal & 25,940 & 24,432 \\
\hline \multirow[t]{2}{*}{ Missouri } & $\begin{array}{l}\text { Alabama and Tennessee } \\
\text { Louisiana and Mississippi } \\
\text { Other states }\end{array}$ & $\begin{array}{r}2,000 \\
40,930 \\
3,205 \\
\end{array}$ & $\begin{array}{r}1,406 \\
46,639 \\
468 \\
\end{array}$ \\
\hline & Subtotal & 46,135 & 48,513 \\
\hline \multirow[t]{2}{*}{ Ohio } & $\begin{array}{l}\text { Louisiana and Mississippi } \\
\text { Other states }\end{array}$ & $\begin{array}{r}10,496 \\
507 \\
\end{array}$ & $\begin{array}{r}8,761 \\
893 \\
\end{array}$ \\
\hline & Subtotal & 11,003 & 9,654 \\
\hline \multirow[t]{2}{*}{ Oklahoma } & $\begin{array}{l}\text { Louisiana and Mississippi } \\
\text { Other states }\end{array}$ & $\begin{array}{r}1,900 \\
350 \\
\end{array}$ & $\begin{array}{r}2,152 \\
186 \\
\end{array}$ \\
\hline & Subtotal & 2,250 & 2,338 \\
\hline Other states & Other states & 5,469 & 4,507 \\
\hline U.S. total & & 410,487 & 341,149 \\
\hline
\end{tabular}


Table 6. Comparison of 1977 Rail Movements of Soybeans as Reported by Survey Respondents and as Estimated trom the 1 Percent Waybili Sampie in Selected States

\begin{tabular}{|c|c|c|c|}
\hline $\begin{array}{l}\text { Originating } \\
\text { state }\end{array}$ & $\begin{array}{l}\text { Destination } \\
\text { state }\end{array}$ & $\begin{array}{l}\text { Survey } \\
\text { results }\end{array}$ & $\begin{array}{c}\text { Waybill } \\
\text { data }\end{array}$ \\
\hline & & \multicolumn{2}{|c|}{ thousands of bushels } \\
\hline \multirow[t]{6}{*}{ Alabama and Tennessee } & $\begin{array}{l}\text { Alabama and Tennessee } \\
\text { Delaware, Maryland, North }\end{array}$ & 14,305 & 9,207 \\
\hline & $\begin{array}{l}\text { Carolina, and Virginia } \\
\text { Florida, Georgia, and South }\end{array}$ & 320 & 323 \\
\hline & Carolina & 1,998 & 2,184 \\
\hline & Kansas and Nebraska & 0 & 333 \\
\hline & Louisiana and Mississippi & 3,857 & 1,758 \\
\hline & Subtotal & 20,480 & 13,805 \\
\hline \multirow[t]{5}{*}{ Arkansas } & Alabama and Tennessee & 371 & 200 \\
\hline & Arkansas & 17,468 & 9,627 \\
\hline & Louisiana and Mississippi & 14,119 & 3,024 \\
\hline & Texas & 204 & 486 \\
\hline & Subtotal & 32,162 & 13,337 \\
\hline \multirow{4}{*}{$\begin{array}{l}\text { Delaware, Maryland, North } \\
\text { Carolina, and Virginia }\end{array}$} & Delaware, Maryland, North & & \\
\hline & Carolina, and Virginia & 4,430 & 3,004 \\
\hline & $\begin{array}{l}\text { Florida, Georgia, and South } \\
\text { Carolina }\end{array}$ & 515 & 280 \\
\hline & Subtotal & 4,945 & 3,284 \\
\hline \multirow{7}{*}{$\begin{array}{l}\text { Florida, Georgia, and South } \\
\text { Carolina }\end{array}$} & Alabama and Tennessee & 640 & 892 \\
\hline & Delaware, Maryland, North & & \\
\hline & Carolina, and Virginia & 548 & 583 \\
\hline & Florida, Georgia, and South & & \\
\hline & Carolina & 10,131 & 7,709 \\
\hline & Louisiana and Mississippi & 1,527 & 1,092 \\
\hline & Subtotal & 12,846 & 10,276 \\
\hline \multirow[t]{14}{*}{ Illino is } & Alabama and Tennessee & 13,258 & 8,095 \\
\hline & Delaware, Maryland, North & & \\
\hline & Carolina, and Virginia & 2,585 & 2,871 \\
\hline & Florida, Georgia, and South & & \\
\hline & Carolina & 2,537 & 1,442 \\
\hline & New York, New Jersey, and & & \\
\hline & Pennsylvania & 2,055 & 656 \\
\hline & Illinois & 12,949 & 13,640 \\
\hline & Indiana & 1,895 & 2,980 \\
\hline & Kentucky & 27 & 1,365 \\
\hline & Louisiana and Mississippi & 2,596 & 553 \\
\hline & Texas & 320 & 653 \\
\hline & Other & 2,708 & 0 \\
\hline & Subtotal & 40,930 & 32,255 \\
\hline \multirow[t]{10}{*}{ Indiana } & Alabama and Tennessee & 1,250 & 1,229 \\
\hline & Delaware, Maryland, North & & \\
\hline & Carolina, and Virginia & 21,213 & 16,473 \\
\hline & Illinois & 1,635 & 566 \\
\hline & Indiana & 173 & 976 \\
\hline & Kentucky & 2,684 & 1,242 \\
\hline & New York, New Jersey, and & & \\
\hline & Pennsylvania & 2,055 & 996 \\
\hline & Other & 4,414 & 0 \\
\hline & Subtotal & 33,424 & $\begin{array}{r}21,482 \\
\text { ontinued }\end{array}$ \\
\hline
\end{tabular}


Table 6-continued

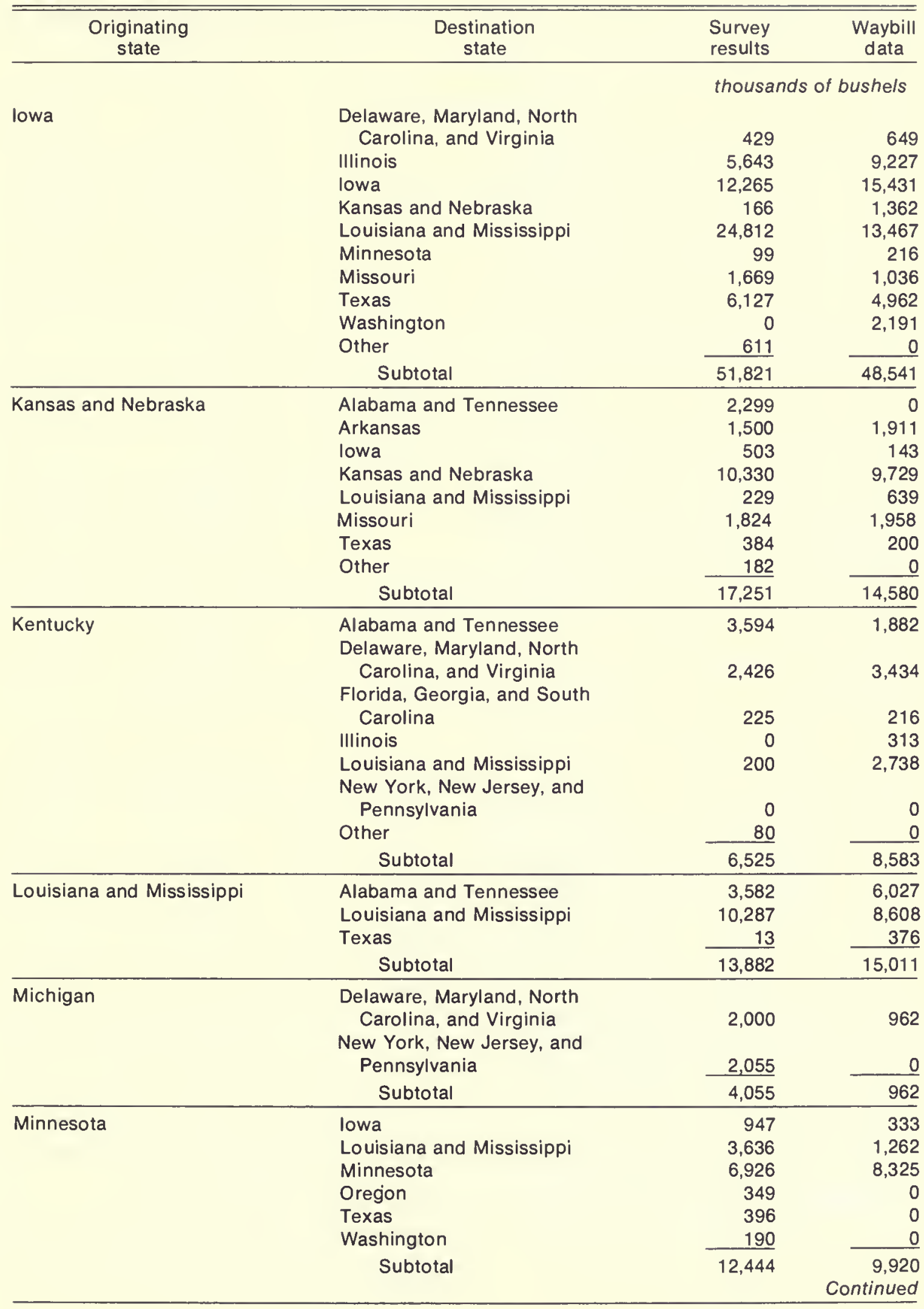




\begin{tabular}{|c|c|c|c|}
\hline $\begin{array}{l}\text { Originating } \\
\text { state }\end{array}$ & $\begin{array}{c}\text { Destination } \\
\text { state }\end{array}$ & $\begin{array}{l}\text { Survey } \\
\text { results }\end{array}$ & $\begin{array}{c}\text { Waybill } \\
\text { data }\end{array}$ \\
\hline & & \multicolumn{2}{|c|}{ thousands of bushels } \\
\hline \multirow[t]{10}{*}{ Missourl } & Alabama and Tennessee & 277 & 280 \\
\hline & Arkansas & 2,905 & 1,948 \\
\hline & Illinois & 3,741 & 6,913 \\
\hline & Kansas and Nebraska & 6,627 & 9,118 \\
\hline & Louisiana and Mississippi & 0 & 2,737 \\
\hline & Missouri & 23,299 & 13,187 \\
\hline & Oregon & 0 & 629 \\
\hline & Texas & 1,229 & 403 \\
\hline & Other & 575 & $\underline{0}$ \\
\hline & Subtotal & 38,653 & 35,215 \\
\hline \multirow[t]{8}{*}{ Ohio } & Delaware, Maryland, North & & \\
\hline & Carolina, and Virginia & 27,669 & 16,963 \\
\hline & Florida, Georgia, and South & & \\
\hline & Carolina & 5,457 & 3,873 \\
\hline & New York, New Jersey, and & & \\
\hline & Pennsylvania & 6,785 & 9,464 \\
\hline & Other & 6,375 & \\
\hline & Subtotal & 46,286 & 30,300 \\
\hline \multirow[t]{5}{*}{ Oklahoma } & Arkansas & 0 & 926 \\
\hline & Kansas and Nebraska & 111 & 256 \\
\hline & Louisiana and Mississippi & 0 & 320 \\
\hline & Texas & 1,852 & 0 \\
\hline & Subtotal & 1,963 & 1,502 \\
\hline \multirow[t]{4}{*}{ South Dakota } & lowa & 1,573 & 0 \\
\hline & Minnesota & 350 & 330 \\
\hline & Texas & 51 & $\underline{0}$ \\
\hline & Subtotal & 1,974 & 330 \\
\hline \multirow[t]{3}{*}{ Texas } & Louisiana and Mississippi & 360 & 646 \\
\hline & Texas & 2,118 & 1,242 \\
\hline & Subtotal & 2,478 & 1,888 \\
\hline \multirow[t]{3}{*}{ Wisconsin } & Illinois & 1,543 & 426 \\
\hline & Minnesota & 178 & $\underline{0}$ \\
\hline & Subtotal & 1,721 & 426 \\
\hline U.S. total & & 343,188 & 261,697 \\
\hline
\end{tabular}

derived from sampling a less than perfectly identified population. The logic of each flow reported in this bulletin has been checked by the university person that organized the survey in each state. Where internal inconsistencies were found, the data and the sampling rates were adjusted with assistance from grain specialists and industry personnel in the state. The flow estimates presented in the following sections represent the best information available on the actual volume of soybeans transported between the regions of the U.S.

\section{OVERVIEW OF MOVEMENTS}

This section summarizes selected data and presents an overview of soybean movement patterns. De- tailed data on receipts and shipments for each region are presented in the last section of this bulletin.

The soybean processing industry, the major domestic outlet for soybeans, has accounted for an average of 56 percent of the total soybean disappearance in the last five years. The industry is composed of 83 plants in 21 states. ${ }^{*}$ Seven states have only one or two plants; in those cases, the publication of flow data for substate areas or even for individual states would reveal information about the activities of individual firms. To preserve the confidentiality of survey responses, flow data were

* John W. Sharp, Grain Facilities in the U.S. Specializing in Originating Grain for Export and Soybean Processing Plants, Research Circular 241, Ohio Agr. Res. and Dev. Center, Wooster, Ohio, September, 1978. 
aggregated across state lines in many instances. The following combinations of states are treated as regions in this report:

Area 6200: New York, New Jersey, and Pennsylvania

Areas 6300: Delaware, Maryland, North Carolina, and Virginia

Area 6400: Florida, Georgia, and South Carolina Area 6500: Alabama and Tennessee

Area 6600: Kansas and Nebraska

In addition, several of Texas's substate areas were combined into a general area (3700). In Minnesota, data for area 2704 were combined with those from area 2703 to avoid disclosure. In several states, such as Arkansas, data for the substate regions were aggregated into estimates for the entire state. In Louisiana, receipts at the soybean processing plants were combined with port elevator receipts (area 7302). Area and state data were aggregated only when necessary to protect confidentiality.

\section{Shipments and Receipts by State}

Grain marketing firms in the United States reported shipping an estimated 1.7 billion bushels of soybeans in 1977. Much of the total amount, of course, is' accounted for by the same grain being shipped in sequence by several firms. The domestic flow patterns for soybeans are illustrated in Figure 3.

About 55 percent of the total volume transported was sent to destinations within the state in which the shipments originated. Those intrastate shipments are summarized in Table 7 . Trucks were the primary carriers of those shipments, transporting about 747 million bushels or more than 80 percent of the total intrastate shipment volume. Rail shipments were the principal mode in the Florida-Georgia-South Carolina area and in Missouri, whereas barge shipments were predominant in Louisiana. Trucking was the primary mode in other parts of the nation.

The greatest volume of intrastate shipments occurred in Illinois and Iowa. Intrastate shipments within those two states amounted to about 40 percent of all such movements. Approximately 37 percent of the nation's soybean processing capacity is located within those states, and these movements reflect that industry's sizeable demands for soybeans.

Figure 3. Patterns of soybean flows to domestic destinations in 1977.

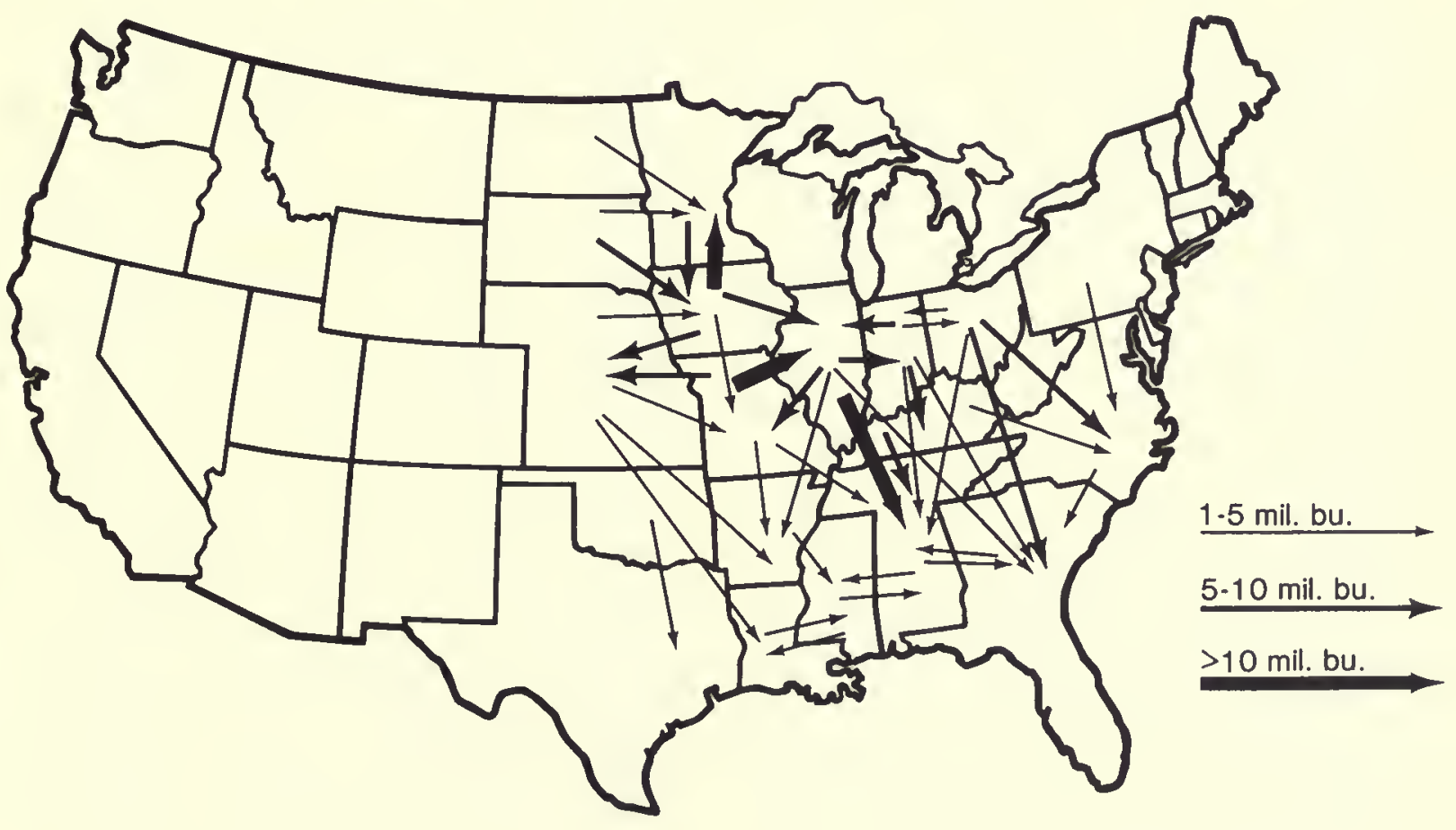


The balance of the volume shipped (45 percent) moved to interstate destinations. For states along the Mississippi River - with the exception of Iowa and Wisconsin - barges provided the principal means of transporting interstate shipments (Table 8). Illinois shipped 161 million bushels of soybeans to destinations in other states, more than any other state. The importance of the Illinois and Mississippi Rivers to Illinois agriculture is evidenced by the fact that over three-fourths of the shipments from Illinois to other states moved by barge. Iowa and Missouri were next in terms of the volume shipped to destinations in other states; they shipped 98 and 79 million bushels, respectively. Rail shipments predominated in Iowa, where they accounted for about two-fifths of the shipments to other states. Over half of the interstate shipments from Missouri firms moved by barge. Other states that shipped more than 50 million bushels to other states were Arkansas, Indiana, and Ohio.

Interstate receipts by mode of transportation are summarized in Table 9. In addition to the 765 million bushels transported between states by commercial carriers, almost 59 million bushels were hauled by farm trucks to grain handlers and processors in other states. The importance of the export market for soybeans, which is focused on Louisiana Gulf ports, is indicated by the fact that more than 40 percent of interstate shipments were destined for firms in Louisiana. More than 90 percent of the soybeans received in Louisiana arrived by barge.

States along the Atlantic coast were important termination points for interstate rail movements. This pattern reflects the importance of export markets served by port elevators located along the Atlantic seaboard. Illinois was the most important destination point for interstate truck shipments; about one-fourth of all such shipments were received there. The Chicago export market is an important drawing force for soybeans produced in northern Indiana and southern Wisconsin.

\section{Movements to Ports}

Table 10 shows the volume of soybeans that moved to port locations from each of the originating states by the three modes of commercial transportation. Figure 4 illustrates the pattern of these

Table 7. 1977 Intrastate Shipments of Soybeans for Each State and Mode of Transportation

\begin{tabular}{|c|c|c|c|c|c|}
\hline \multirow{2}{*}{$\begin{array}{l}\text { Originating } \\
\text { state }\end{array}$} & \multicolumn{4}{|c|}{ Mode of transportation } & \multirow[b]{2}{*}{ Total } \\
\hline & Rail & Truck & Barge & $\begin{array}{l}\text { Farm } \\
\text { truck }^{a}\end{array}$ & \\
\hline & \multicolumn{5}{|c|}{ thousands of bushels } \\
\hline Alabama and Tennessee .......... & 9,532 & 51,879 & 9,727 & 0 & 71,138 \\
\hline $\begin{array}{l}\text { Arkansas } \ldots \ldots \ldots \ldots \ldots \ldots \ldots \ldots \\
\text { Delaware Marvland North }\end{array}$ & 17,468 & 43,179 & 0 & 0 & 60,647 \\
\hline \multicolumn{5}{|l|}{ Delaware, Maryland, North } & 18,727 \\
\hline Florida, Georgia, and South Carolina & 10,150 & 8,750 & 0 & 0 & 18,900 \\
\hline Illinois $\ldots \ldots \ldots \ldots \ldots \ldots \ldots \ldots$ & 12,949 & 189,509 & 1,321 & 0 & 203,779 \\
\hline Indiana $\ldots \ldots \ldots \ldots \ldots \ldots \ldots$ & 173 & 57,442 & 0 & 0 & 57,615 \\
\hline lowa $\ldots \ldots \ldots \ldots \ldots \ldots \ldots \ldots$ & 12,265 & 148,687 & 0 & 0 & 160,952 \\
\hline 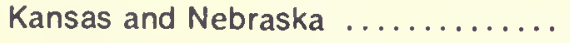 & 9,168 & 27,384 & 0 & 0 & 36,552 \\
\hline 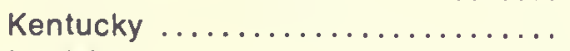 & 80 & 2,434 & 0 & 0 & 2,514 \\
\hline 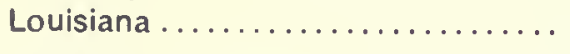 & 1,613 & 27,355 & 45,381 & 0 & 74,349 \\
\hline Michigan $\ldots \ldots \ldots \ldots \ldots \ldots \ldots$ & 0 & 1,678 & 0 & 0 & 1,678 \\
\hline Minnesota $\ldots \ldots \ldots \ldots \ldots \ldots \ldots$ & 6,926 & 67,555 & 0 & 90 & 74,571 \\
\hline Mississippi ................... & 5,922 & 18,630 & 0 & 0 & 24,552 \\
\hline 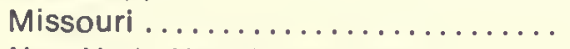 & 23,299 & 19,495 & 3,205 & 0 & 45,999 \\
\hline \multicolumn{6}{|l|}{ New York, New Jersey, and } \\
\hline Pennsylvania ................. & 0 & 485 & 0 & 0 & 485 \\
\hline Ohio ........... & 4,064 & 59,508 & 0 & 0 & 63,572 \\
\hline Oklahoma $\ldots \ldots \ldots \ldots \ldots \ldots \ldots$ & 0 & 214 & 0 & 0 & 214 \\
\hline Texas $\ldots . . \ldots \ldots \ldots \ldots \ldots \ldots$ & 2,118 & 7,855 & 0 & 0 & 9,973 \\
\hline Wisconsin $\ldots \ldots \ldots \ldots \ldots \ldots$ & $\underline{0}$ & 757 & $\underline{0}$ & $\underline{0}$ & 757 \\
\hline Total volume $\ldots \ldots \ldots \ldots \ldots \ldots$ & 119,366 & 746,515 & 60,830 & 90 & 926,801 \\
\hline Percentage of total volume $\ldots . . .$. & 12.9 & 80.5 & 6.6 & 0 & 100.0 \\
\hline
\end{tabular}

- This column reports sales by elevators to farmers within the state. Not all states included farm sales in their questionnaires, so these data are incomplete and underestimate total shipments to farmers. 
Table 8. 1977 Interstate Shipments of Soybeans for Each State and Mode of Transportation

\begin{tabular}{|c|c|c|c|c|c|}
\hline \multirow{2}{*}{$\begin{array}{l}\text { Originating } \\
\text { state }\end{array}$} & \multicolumn{4}{|c|}{ Mode of transportation } & \multirow[b]{2}{*}{ Total } \\
\hline & Rail & Truck & Barge & $\begin{array}{l}\text { Farm } \\
\text { truck }^{a}\end{array}$ & \\
\hline & \multicolumn{5}{|c|}{ thousands of bushels } \\
\hline Alabama and Tennessee ........... & 10,948 & 10,509 & 19,595 & 0 & 41,052 \\
\hline $\begin{array}{l}\text { Arkansas } \ldots \ldots \ldots \ldots \ldots \ldots \ldots \ldots \ldots \\
\text { Delaware, Maryland, North }\end{array}$ & 14,694 & 7,310 & 38,586 & 0 & 60,590 \\
\hline Carolina, and Virginia .......... & 1,306 & 14,260 & 4,273 & 0 & 19,839 \\
\hline Florida, Georgia, and South Carolina & 2,696 & 2,271 & 2,429 & 0 & 7,396 \\
\hline Illinois $\ldots \ldots \ldots \ldots \ldots \ldots \ldots \ldots$ & 27,312 & 10,289 & 123,758 & 0 & 161,359 \\
\hline Indiana $\ldots \ldots \ldots \ldots \ldots \ldots \ldots$ & 33,251 & 31,287 & 8,595 & 0 & 73,133 \\
\hline lowa $\ldots \ldots \ldots \ldots \ldots \ldots \ldots \ldots$ & 39,556 & 28,118 & 30,307 & 0 & 97,981 \\
\hline Kansas and Nebraska ............ & 8,047 & 3,486 & 1,878 & 0 & 13,411 \\
\hline 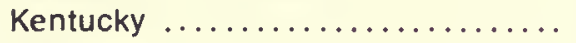 & 6,445 & 1,831 & 11,680 & 0 & 19,956 \\
\hline 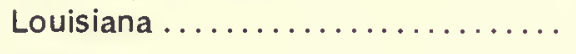 & 13 & 12,798 & 0 & 0 & 12,811 \\
\hline Michigan $\ldots \ldots \ldots \ldots \ldots \ldots \ldots$ & 4,055 & 13,389 & 0 & 0 & 17,444 \\
\hline 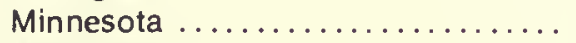 & 5,518 & 5,456 & 24,590 & 0 & 35,564 \\
\hline Mississippi ................... & 6,334 & 4,647 & 26,433 & 0 & 37,414 \\
\hline 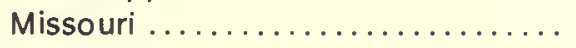 & 15,354 & 21,040 & 42,930 & 0 & 79,324 \\
\hline New Mexico $\ldots \ldots \ldots \ldots \ldots \ldots \ldots$ & 0 & 3 & 0 & 0 & 3 \\
\hline \multicolumn{6}{|l|}{ New York, New Jersey, and } \\
\hline Pennsylvania............ & 0 & 4,902 & 0 & 0 & 4,902 \\
\hline 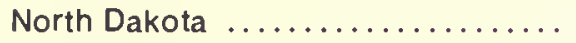 & 17 & 3,865 & 0 & 0 & 3,882 \\
\hline Ohio $\ldots \ldots \ldots \ldots \ldots \ldots \ldots \ldots$ & 42,222 & 4,961 & 11,003 & 0 & 58,186 \\
\hline Oklahoma $\ldots \ldots \ldots \ldots \ldots \ldots$ & 1,963 & 1,309 & 2,250 & 0 & 5,522 \\
\hline 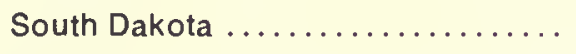 & 1,974 & 6,031 & 0 & 0 & 8,005 \\
\hline Texas $\ldots \ldots \ldots \ldots \ldots \ldots \ldots$ & 360 & 108 & 0 & 0 & 468 \\
\hline Wisconsin $\ldots \ldots \ldots \ldots \ldots \ldots \ldots$ & 1,721 & 4,037 & 1,350 & $\underline{0}$ & 7,108 \\
\hline Total volume $\ldots \ldots \ldots \ldots \ldots$ & 223,786 & 191,907 & 349,657 & 0 & 765,350 \\
\hline Percentage of total volume $\ldots \ldots \ldots$ & 29.2 & 25.1 & 45.7 & 0 & 100.0 \\
\hline
\end{tabular}

a This column reports sales by elevators to farmers in other states. Not all states included farm sales in their questionnaires, so these data are incomplete and underestimate total shipments to farmers.

movements, and Figure 5 shows the share that originated in each state.

Seven states shipped more than $\mathbf{4 0}$ million bushels to port areas. Illinois was the source of the greatest volume of soybeans destined for export regions, originating almost 122 million bushels. Quantities that were reshipped by Chicago-area firms to other port areas are excluded from this total. Almost all of the Illinois shipments went to the Gulf by barge.

Ohio and Iowa were second and third, respectively, in the volume shipped to points of export. Each contributed more than 60 million bushels or about 10 percent of the total amount shipped to port facilities. About 45 percent of Ohio soybeans destined for export moved to port facilities in the Toledo area. About 39 percent went by rail to the East Coast, and 16 percent were sent by barge to the Gulf. Nearly all of the Iowa export shipments went to the Gulf ports, about half by rail and half by barge.
Louisiana and Arkansas ranked fourth and fifth, respectively, in the quantity shipped to port areas. Each state shipped more than 50 million bushels. Indiana and Missouri each contributed more than 40 million bushels toward the shipments to port areas. The most important destinations for Indiana soybeans were the Atlantic ports. In 1977 Indiana firms shipped almost 23 million bushels to those ports. All shipments originating in Missouri moved to Gulf port elevators, almost all by barge.

Estimated receipts at all port locations in 1977 totaled 637 million bushels, of which Louisiana port facilities received about 60 percent (Table 11). The East Gulf port area ranked second in volume. Receipts at that location in 1977 totaled over 70 million bushels. Receipts at the South Atlantic and Toledo-area ports were 55 million and 47 million bushels, respectively. The combined receipts at these four port areas represented about 87 percent of the volume received at all ports, and the volume 
of soybeans inspected for export at these ports was more than 90 percent of the total volume of soybeans exported from the United States.

Barges carried about 60 percent of the soybeans received at ports in 1977. Rail and truck shipments accounted for 23 percent and 16 percent, respectively, of the volume received. The strong position of Louisiana Gulf port facilities in the export of soybeans is highly dependent upon a steady flow of soybeans down the Mississippi River system.

Shippers not located adjacent to the major rivers are turning increasingly to unit trains as a means of moving soybeans to export points. Most unit train shipments that originated in Ohio and Indiana during 1977 moved to Atlantic ports. In contrast, those that originated in Iowa were usually destined for Gulf ports. Unit train shipments of soybeans were not found to be important in Illinois, where local processors are the primary outlet for the portion of the soybeans that are not marketed through river facilities. All unit train shipments of soybeans in 1977 moved to export areas.
Most of the soybeans received at Great Lakes ports were transported by truck. These port areas will likely continue to be dependent upon supplies trucked in from nearby production areas. With only a few exceptions, truck shipments received at any of the port areas originated within a few hundred miles of the port.

\section{Foreign Destinations for U.S. Exports}

Soybeans shipped from the various origins to a specific port area are commingled at the port elevator. It is not possible to trace the movement of soybeans from a particular state through the port system to their final destination, and therefore no attempt was made to determine whether a particular ocean vessel was loaded with, for example, Ohio soybeans or Illinois soybeans. It is nonetheless of interest to examine one more link in the market chain that connects U.S. farmers with foreign processors.

The destination countries for soybeans exported from the major export regions of the United States

Table 9. 1977 Interstate Recelpts of Soybeans for Each State and Mode of Transportation

\begin{tabular}{|c|c|c|c|c|c|}
\hline \multirow{2}{*}{$\begin{array}{l}\text { Destination } \\
\text { state }\end{array}$} & \multicolumn{4}{|c|}{ Mode of transportation } & \multirow[b]{2}{*}{ Total } \\
\hline & Rail & Truck & Barge & $\begin{array}{c}\text { Farm } \\
\text { truck }^{a}\end{array}$ & \\
\hline & \multicolumn{5}{|c|}{ thousands of bushels } \\
\hline Alabama and Tennessee.. & 33,020 & 14,989 & 17,752 & 1,666 & 67,427 \\
\hline Arkansas $\ldots \ldots \ldots \ldots \ldots$ & 4,405 & 2,639 & 4,000 & 7,450 & 18,494 \\
\hline California ............. & 295 & 0 & 0 & 0 & 295 \\
\hline \multicolumn{6}{|l|}{ Delaware, Maryland, North } \\
\hline Carolina, and Virginia $\ldots \ldots \ldots \ldots$ & 57,981 & 17,627 & 4,273 & 10,001 & 89,882 \\
\hline Florida, Georgia, and South Carolina & 16,079 & 1,513 & 0 & 9,453 & 27,045 \\
\hline Illinois ....................... & 12,562 & 46,091 & 0 & 9,414 & 68,067 \\
\hline Indiana $\ldots \ldots \ldots \ldots \ldots \ldots \ldots \ldots$ & 1,895 & 10,759 & 0 & 991 & 13,645 \\
\hline lowa.......................... & 3,023 & 11,301 & 0 & 5,370 & 19,694 \\
\hline Kansas and Nebraska ............ & 8,032 & 11,310 & 0 & 5,110 & 24,452 \\
\hline Kentucky ..................... & 2,711 & 7,222 & 0 & 500 & 10,433 \\
\hline Louisiana. . & 31,075 & 3,251 & 300,142 & 0 & 334,468 \\
\hline Minnesota & 644 & 16,897 & 0 & 2,065 & 19,606 \\
\hline Mississippi . . & 22,806 & 9,333 & 23,490 & 0 & 55,629 \\
\hline Missouri ..................... & 4,661 & 8,682 & 0 & 0 & 13,343 \\
\hline \multicolumn{6}{|l|}{ New York, New Jersey, and } \\
\hline Pennsylvania ............ & 12,950 & 705 & 0 & 0 & 13,655 \\
\hline$\ldots \ldots \ldots \ldots \ldots \ldots \ldots \ldots$ & 350 & 17,220 & 0 & 6,519 & 24,089 \\
\hline Oklahoma $\ldots \ldots \ldots \ldots \ldots \ldots \ldots$ & 0 & 0 & 0 & 113 & 113 \\
\hline Oregon...$\ldots \ldots \ldots \ldots \ldots \ldots$ & 531 & 34 & 0 & 0 & 565 \\
\hline Texas $\ldots \ldots \ldots \ldots \ldots \ldots \ldots \ldots$. & 10,576 & 10,549 & 0 & 0 & 21,125 \\
\hline Washington .................... & 190 & 253 & 0 & 0 & 443 \\
\hline Wisconsin $\ldots \ldots \ldots \ldots \ldots \ldots \ldots$ & 0 & 1,532 & $\underline{0}$ & 204 & 1,736 \\
\hline Total volume $\ldots \ldots \ldots \ldots \ldots \ldots$ & $\overline{223,786}$ & 191,907 & 349,657 & 58,856 & 824,206 \\
\hline Percentage of total volume $\ldots . . .$. & 27.2 & 23.3 & 42.2 & 7.1 & 100.0 \\
\hline
\end{tabular}


Table 10. 1977 Movements of Soybeans to Points of Export for Each Originating State by Three Modes of Transportation

\begin{tabular}{llllll}
\hline \hline $\begin{array}{l}\text { Originating } \\
\text { state }\end{array}$ & $\begin{array}{l}\text { Export } \\
\text { region }\end{array}$ & \multicolumn{3}{c}{ Mode of transportation } & Total \\
\cline { 3 - 6 } & Rail & Truck & Barge & \\
\hline
\end{tabular}

Alabama and Tennessee

Arkansas

Delaware, Maryland, North Carolina,

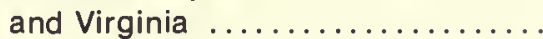

Florida, Georgia, and South Carolina .

Illinois

Indiana

lowa

Kansas and Nebraska

Kentucky

Louisiana

Michigan

Minnesota

Mississippi

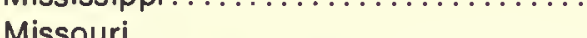

New York, New Jersey, and

Pennsylvania.

Ohio

Oklahoma

South Dakota

Texas

Wisconsin

Chicago area

All states

Percentage of total volume
Gulf .........

Gulf ..........

Atlantic ......

Atlantic .......

Gulf ..........

Lakes.........

Atlantic .......

Gulf ..........

Lakes .........

Atlantic .......

Gulf ..........

Lakes.........

Atlantic .......

Gulf ..........

Pacific ........

Gulf .........

Pacific ........

Gulf ..........

Gulf ..........

Lakes .........

Atlantic .......

Gulf ...........

Pacific ........

Canada .......

Gulf ..........

Gulf .........

Atlantic .......

Lakes .........

Atlantic .......

Gulf ..........

Gulf ..........

Gulf .........

Pacific ........

Gulf ..........

Lakes.........

Gulf ..........

Lakes.........

Atlantic .......

Gulf ..........

Canada .......

Lakes .........

Atlantic .......

Gulf .........

Pacific ........

Canada ........

Canada ........
3,402

14,470

991

1,540

94

1,952

1,447

3,713

350

22,949

591

2,664

429

31,144

295

2,756

182

21

1,626

0

4,055

4,032

539

0

7,332

1,804

0

3,713

26,077

164

0

51

0

2,283

1,432

0

111

2,866

0

669

10,222

60,354

73,483

1,016

669

145,744

23.1 thousands of bushels

$\begin{array}{lll}1,766 & 26,530 & 31,698 \\ 3,359 & 38,586 & 56,415\end{array}$

1,436

1,950

642

5,657

5,119

7,546

$0 \quad 3,490$

2,429

3,165

1,321

8,930

1,447

$107,548 \quad 111,261$

12,307

0

12,657

22,949

$8,120 \quad 8,711$

641

3,305

429

0

0

0

253

0

19,165

14,036

0

0

193

177

0

$\begin{array}{rr}29,720 & 60,864 \\ 0 & 295\end{array}$

$1,878 \quad 4,634$

435

$11,393 \quad 11,414$

$45,381 \quad 66,172$

14,036

4,055

$24,540 \quad 28,572$

539

193

$26,383 \quad 33,892$

$40,930 \quad 42,734$

1,263

26,106

0

0

0

34

7,469

3,015

$\begin{array}{lr}0 & 1,263 \\ 0 & 29,819\end{array}$

$\begin{array}{ll}0 & 26,077\end{array}$

$10,496 \quad 10,660$

$2,250 \quad 2,250$

51

34

9,752

4,447

$\begin{array}{rr}1,350 & 1,350 \\ 0 & 111\end{array}$

2,866

$1,670 \quad 1,670$

871

$1,321 \quad 80,281$

$5,119 \quad 70,122$

68,738

4,649

32,578

287

395

99,671

379,204

485,265

1,303

1,064

15.8

631,059

61.1

100.0 
Figure 4. Patterns of soybean fiows to port areas in 1977.

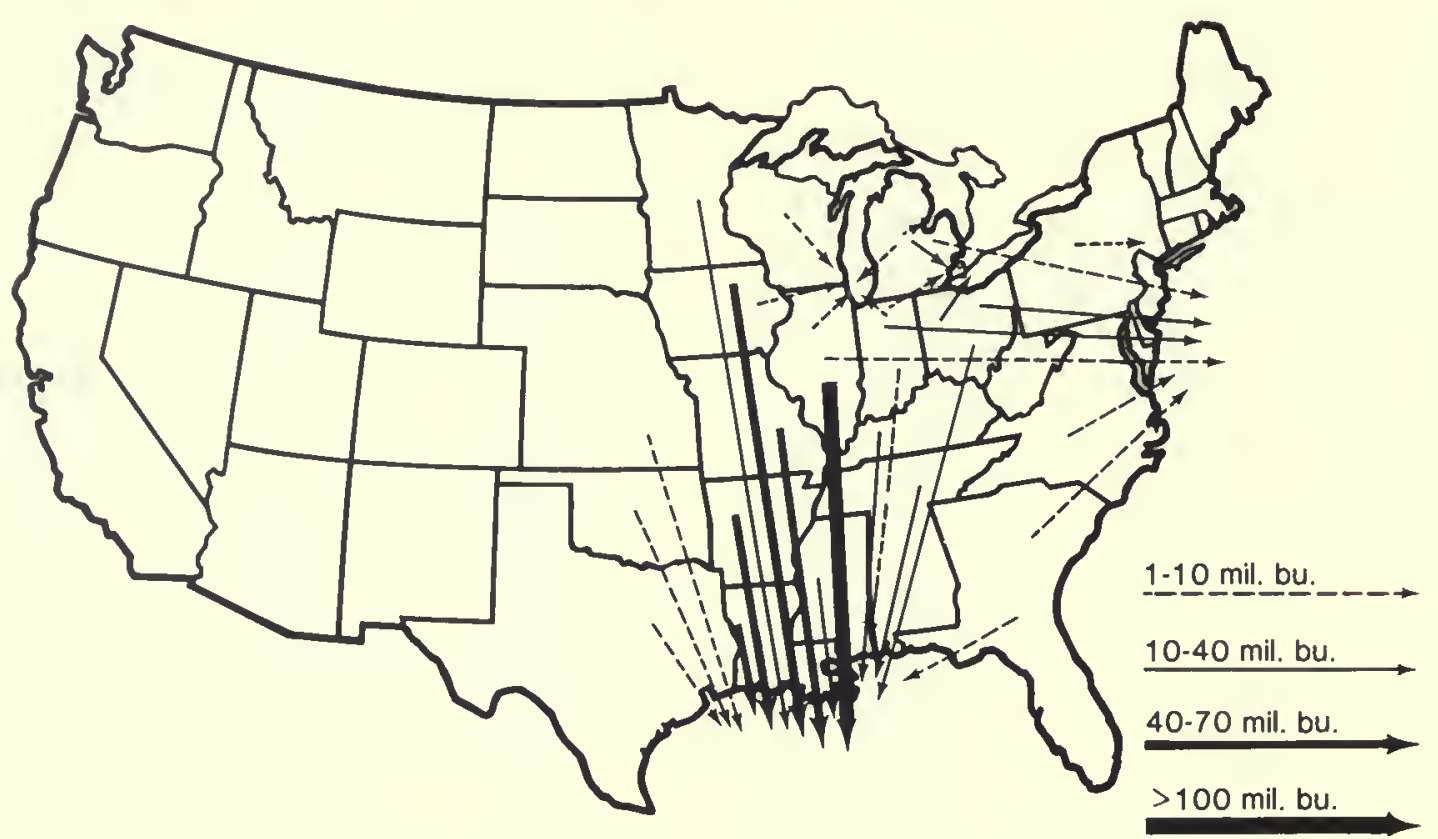

Figure 5. Proportion of 1977 soybean movements to export regions from each originating state.

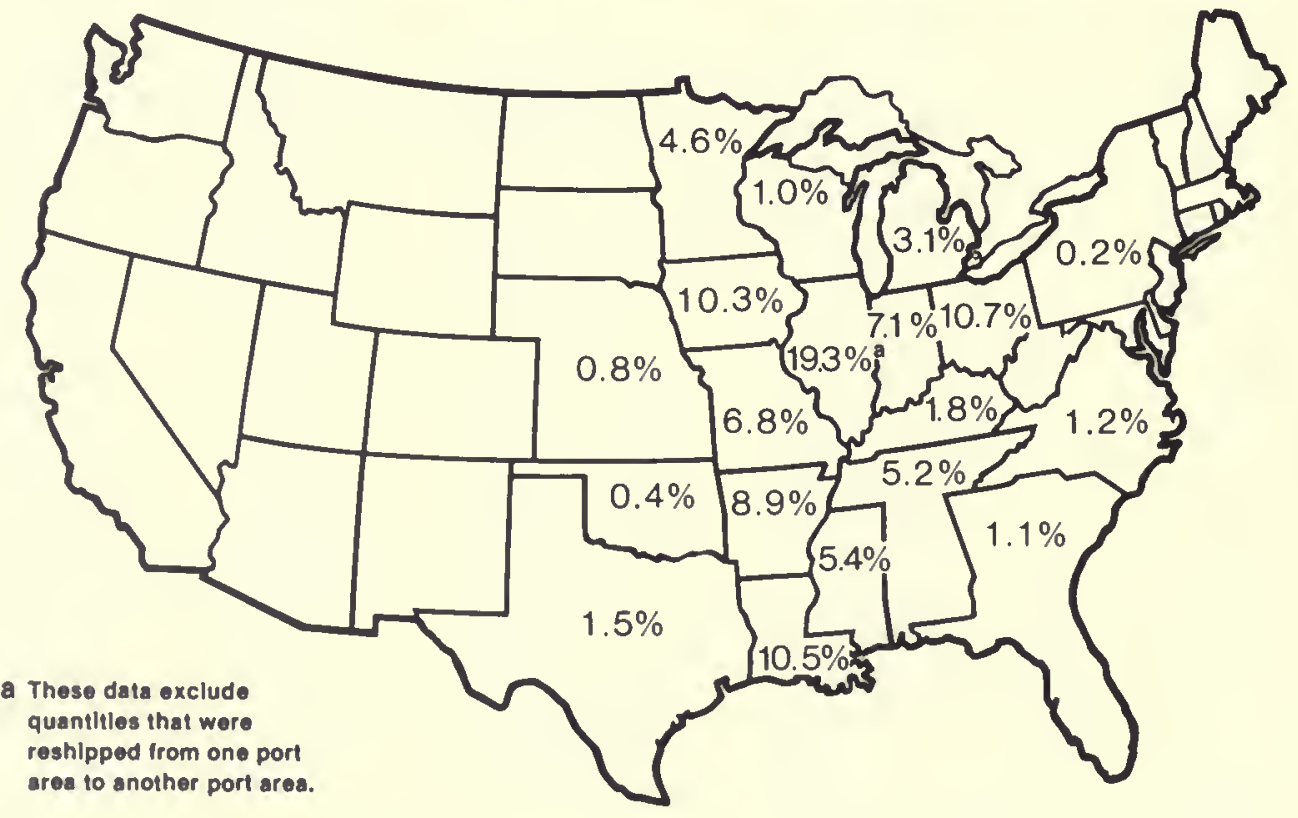


are shown in Table 12. In 1977 Japan purchased 140 million bushels or 24 percent of the total volume exported, making that nation the leading buyer of U.S. soybeans. The Netherlands, the second most important destination for U.S. soybeans, received 115 million bushels. Spain and the Federal Republic of Germany each purchased more than 40 million bushels, and Italy purchased 33 million bushels. Mexico ranked sixth in the volume of soybeans purchased, accounting for almost 30 million bushels.

\section{RECEIPTS AND SHIPMENTS BY AREA}

Estimates of the flow of soybeans by each mode of transportation and for every study region are presented in Tables 13-110. These estimates represent the most comprehensive and best data available on the volume of soybeans transported between each of the regions of the United States.
A detailed study of the flows will likely lead some readers to the conclusion that there are inefficiencies in the shipment of grain among states. Shipping soybeans in both directions between two states is one example of an apparent inefficiency in the marketing pattern. However, most of the shipments reported in this study reflect sellers' attempts to take advantage of profitable marketing opportunities that occur at a particular moment. It is not possible to provide a rationale for all of the movements without complete knowledge of daily price and transportation relationships. Local supply and demand vary throughout the marketing year, and buyers constantly seek the most economical supply source. Changes in supplies, demands, and transportation costs result in frequent changes in the most profitable shipping pattern.

The availability of storage space at harvest time is also an important factor in determining soybean

Table 11. 1977 Recelpts of Soybeans at Port Areas by Each Mode of Transportation

\begin{tabular}{|c|c|c|c|c|c|c|}
\hline \multirow{2}{*}{$\begin{array}{c}\text { Export region } \\
\text { and } \\
\text { port area }\end{array}$} & \multicolumn{4}{|c|}{ Mode of transportation } & \multirow{2}{*}{ Total } & \multirow{2}{*}{$\begin{array}{l}\text { Inspec- } \\
\text { tions for } \\
\text { export }^{b}\end{array}$} \\
\hline & Rail & Truck & Barge & $\begin{array}{l}\text { Farm } \\
\text { truck }^{a}\end{array}$ & & \\
\hline
\end{tabular}

\section{GREAT LAKES REGION}

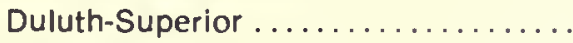

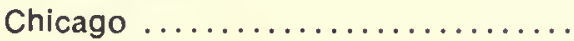

Toledo.........................

Saginaw ....................

Subtotal ................. 10,222

ATLANTIC REGION

North Atlantic . . . . . . . . . . . . . . . 12,950

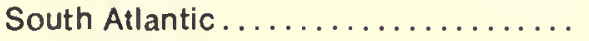

Subtotal

47,404

60,354

\section{GULF REGION}

East Gulf ...................

Louisiana Gulf ..................

North Texas Gulf ...............

South Texas Gulf...............

Subtotal

31,652

31,230

10,601

$\frac{0}{73,483}$

\section{PACIFIC REGION}

Columbia River .................

Puget Sound ..................

California ...................

Subtotal

Total receipts

Percentage of total receipts

145,075

22.8

\begin{tabular}{rr}
0 & 0 \\
6,159 & 21,224 \\
4,063 & 39,390 \\
0 & 1,148 \\
\hline 10,222 & 61,762
\end{tabular}

$\begin{array}{r}0 \\ 1,321 \\ 0 \\ 0 \\ \hline 1,321\end{array}$

$\begin{array}{r}1,190 \\ 3,459 \\ \hline 4,649\end{array}$

$\begin{array}{r}0 \\ 5,119 \\ \hline 5,119\end{array}$

0
800
800

$\begin{array}{r}0 \\ 787 \\ 3,342 \\ 0 \\ \hline 4,129\end{array}$

$\begin{array}{r}0 \\ 25,491 \\ 46,795 \\ 1,148 \\ \hline 77,434\end{array}$

14,187

47,088

1,317

62,592

12,287

53,218

65,505

56,782

70,922

68,225

368,153

27,447

387,502

27,491

16,890

345,473

0
0

32,578

379,204

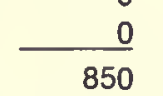

$\frac{0}{486,115}$

463,825
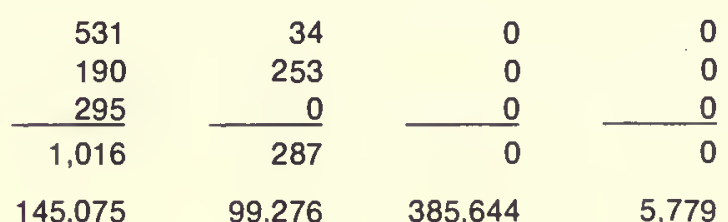

$\begin{array}{r}565 \\ 443 \\ 295 \\ \hline 1,303\end{array}$

605

17

295

917

385,644

5,779

635,774

592,839

15.6

60.7

0.9

100.0

Note: These data exclude shipments to Canada that are reported in Table 10.

a This column reports grain delivered by farmers directly to elevators in each port area.

- Inspections for export conducted under the United States Grain Standards Act and reported in Grain Market News, Agricultural Marketing Service, U.S. Department of Agriculture, Vol. 26, No. 2 (January 13, 1978), p. 18. 
Table 12. 1977 Exports of U.S. Soybeans from Canada and the United States by Port Region and Destination

\begin{tabular}{|c|c|c|c|c|c|c|}
\hline \multirow[b]{2}{*}{ Destination } & \multicolumn{5}{|c|}{ Export region } & \multirow[b]{2}{*}{ Total } \\
\hline & Canada & $\begin{array}{l}\text { Great } \\
\text { Lakes }\end{array}$ & Atlantic & Gulf & Pacific & \\
\hline & \multicolumn{6}{|c|}{ thousands of bushels } \\
\hline Australia ............ & 0 & 0 & 0 & 534 & 0 & 534 \\
\hline Belgium ............ & 0 & 1,341 & 233 & 13,351 & 0 & 14,925 \\
\hline Canada $^{n} \ldots \ldots \ldots \ldots$ & 0 & 10,717 & 0 & 0 & 0 & 10,717 \\
\hline China, Rep. of (Taiwan) & 0 & 0 & 0 & 22,668 & 0 & 22,668 \\
\hline Cyprus .............. & 0 & 0 & 0 & 507 & 0 & 507 \\
\hline Denmark ........... & 150 & 2,625 & 3,217 & 7,711 & 0 & 13,703 \\
\hline Dominican Rep. ....... & 0 & 0 & 0 & 704 & 0 & 704 \\
\hline Egypt ............ & 0 & 0 & 0 & 1,543 & 0 & 1,543 \\
\hline $\begin{array}{l}\text { France } . . . . . \cdots \cdots \\
\text { Germany, Fed. }\end{array}$ & 410 & 607 & 14,395 & 2,220 & 0 & 17,632 \\
\hline Rep. of $(W) \ldots \ldots \ldots$ & 0 & 4,022 & 926 & 36,903 & 0 & 41,851 \\
\hline Greece.............. & 0 & 1,344 & 0 & 1,124 & 0 & 2,468 \\
\hline Indonesia ........... & 1,012 & 0 & 1,750 & 2,348 & 0 & 5,110 \\
\hline Israel .............. & 0 & 0 & 5,493 & 9,464 & 0 & 14,957 \\
\hline Italy $\ldots \ldots \ldots \ldots \ldots$ & 288 & 0 & 4,480 & 28,563 & 0 & 33,331 \\
\hline Jamaica ............. & 0 & 0 & 0 & 770 & 0 & 770 \\
\hline Japan ............. & 6,284 & 12,534 & 8,384 & 112,216 & 859 & 140,277 \\
\hline Korea, Rep. of . . ....... & 638 & 0 & 917 & 5,205 & 0 & 6,760 \\
\hline Lebanon ............ & 0 & 434 & 0 & 173 & 0 & 607 \\
\hline Malaysia ............ & 0 & 0 & 0 & 0 & 58 & 58 \\
\hline Mexico ............. & 0 & 0 & 147 & 29,815 & 0 & 29,962 \\
\hline Morocco ............. & 0 & 971 & 0 & 4,504 & 0 & 5,475 \\
\hline Netherlands .......... & 1,203 & 3,760 & 5,256 & 104,587 & 0 & 114,806 \\
\hline Norway ............. & 0 & 1,600 & 0 & 6,093 & 0 & 7,693 \\
\hline Peoples Rep. of China . & 282 & 591 & 0 & 1,148 & 0 & 2,021 \\
\hline Peru ............... & 0 & 0 & 0 & 961 & 0 & 961 \\
\hline Philippines .......... & 0 & 0 & 864 & 495 & 0 & 1,359 \\
\hline Portugal ............ & 0 & 0 & 1,480 & 4,455 & 0 & 5,935 \\
\hline 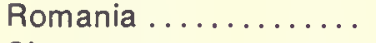 & 0 & 0 & 0 & 6,266 & 0 & 6,266 \\
\hline Singapore ........... & 0 & 0 & 0 & 631 & 0 & 631 \\
\hline Spain .............. & 1,181 & 4,096 & 8,642 & 29,729 & 0 & 43,648 \\
\hline Thailand ............ & 0 & 0 & 2,403 & 0 & 0 & 2,403 \\
\hline United Kingdom ....... & 903 & 5,050 & 3,399 & 6,560 & 0 & 15,912 \\
\hline U.S.S.R. . . . . . . . . & 0 & 549 & 3,519 & 18,808 & 0 & 22,876 \\
\hline Venezuela........... & 0 & 0 & 0 & 1,086 & 0 & 1,086 \\
\hline Yugoslavia .......... & 0 & 0 & 0 & 1,683 & 0 & 2,683 \\
\hline Total .............. & 12,351 & 50,241 & 65,505 & 463,825 & 917 & 592,839 \\
\hline
\end{tabular}

Source: Canadian Grain Commission and data on inspections for export under the U.S. Grain Standards Act as reported in Grain Market News, Agricultural Marketing Service, U.S. Department of Agriculture, Vol. 26, No. 5 (February 3, 1978), pp. 11-15.

- The quantity of grain inspected at U.S. ports for shipment to Canada is reduced by the amount of U.S. grain exported from Canadian ports as reported by the Canadian Grain Commission. It is assumed that this resid ual amount of grain is held in Canada for later export or consumption. 
shipments. If local storage facilities are filled with corn when soybeans move from the farms, country elevators may be forced to ship soybeans to various terminal or processing locations for storage. Later in the year supplies in the local region may be exhausted, and processors in that area will begin purchasing soybeans from outside sources, reversing the earlier outbound flow. Many other factors, such as the availability of transportation, have a substantial impact on soybean movements. An in- adequate supply of rail cars during periods of peak movement may force soybeans to flow in a pattern that is not the most economical.

A detailed analysis of the influence of these factors is beyond the scope of this publication. Readers interested in more detailed information about the types of firms involved in soybean movements and the seasonality of those movements should contact Agricultural Experiment Station representatives in the participating states. 
TABLE 13. 1977 SOYBEAN RECEIPTS FROM UARIDUS ORIGINS BY FIRMS IN AREA 3000, ARKANSAS

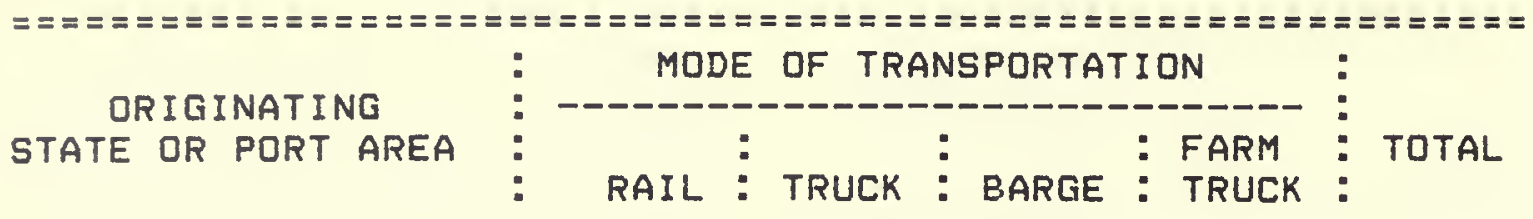
(THOUSANDS OF BUSHELS)

$\begin{array}{llrrrrr}2256 & \text { ILLINOIS } & 0 & 0 & 2440 & 0 & 2440 \\ 2260 & \text { ILLINOIS } & 0 & 0 & 1560 & 0 & 1560 \\ 2500 \text { MISSISSIPPI } & 0 & 645 & 0 & 0 & 645 \\ 2900 \text { MISSOURI } & 2905 & 1919 & 0 & 5350 & 10174 \\ 3000 \text { ARKANSAS } & 17468 & 43179 & 0 & 103070 & 163717 \\ 3100 & \text { LOUISIANA } & 0 & 0 & 0 & 900 & 900 \\ 3600 \text { OKLAHOMA } & 0 & 0 & 0 & 1200 & 1200 \\ 3745 \text { TEXAS } & 1500 & 0 & 0 & 0 & 75 \\ \text { G600 KS \& NE } & --1500 \\ \text { TOTAL UOLUME } & 21873 & 45818 & 4000 & 110520 & 182211\end{array}$

TABLE 14. 1977 SOYBEAN SHIPMENTS TO UARIOUS DESTINATIONS BY FIRMS IN AREA 3000, ARKANSAS

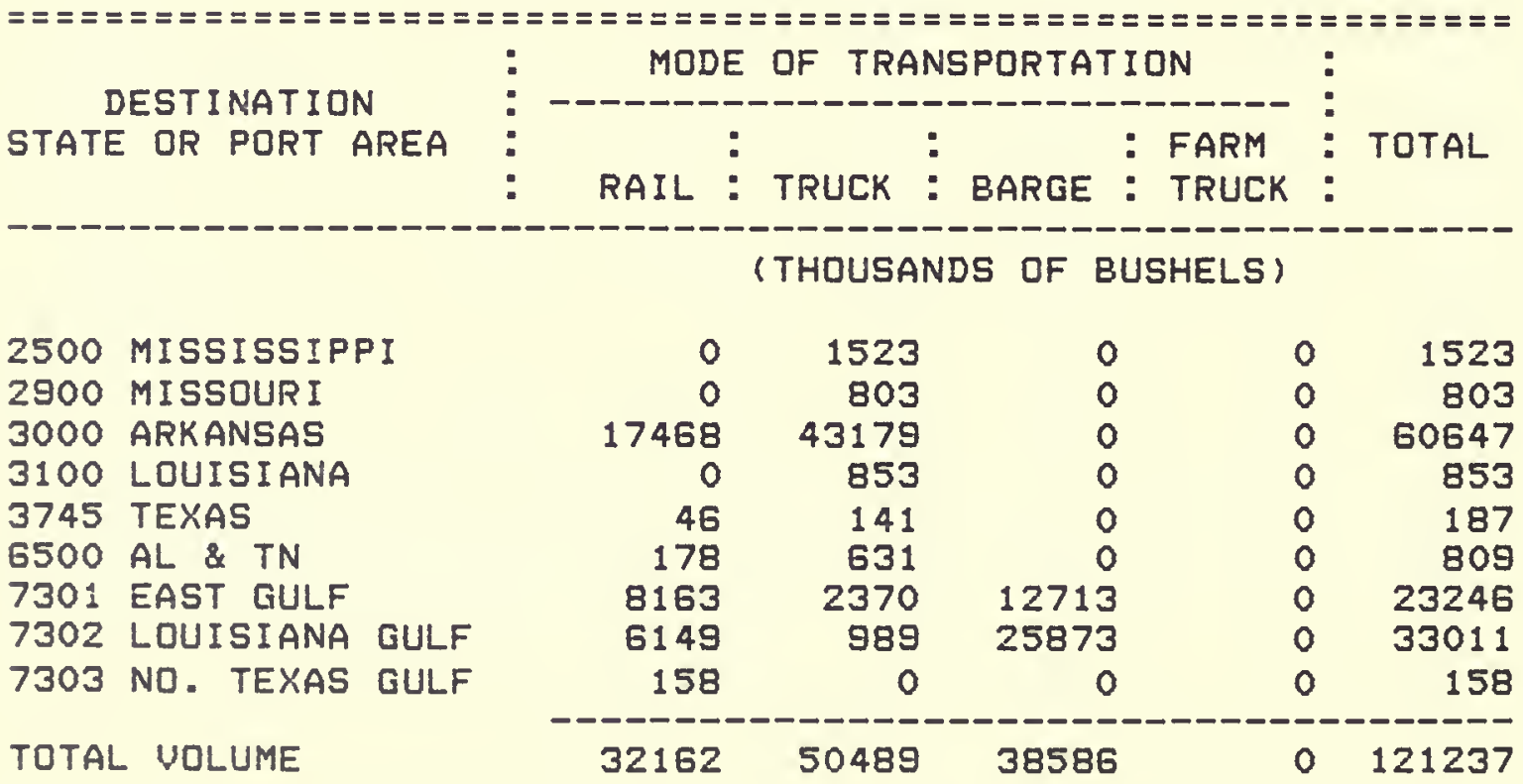


TABLE 15. 1977 SOYBEAN RECEIPTS FROM UARIOUS ORIGINS BY FIRMS IN AREA 225G, ILLINOIS

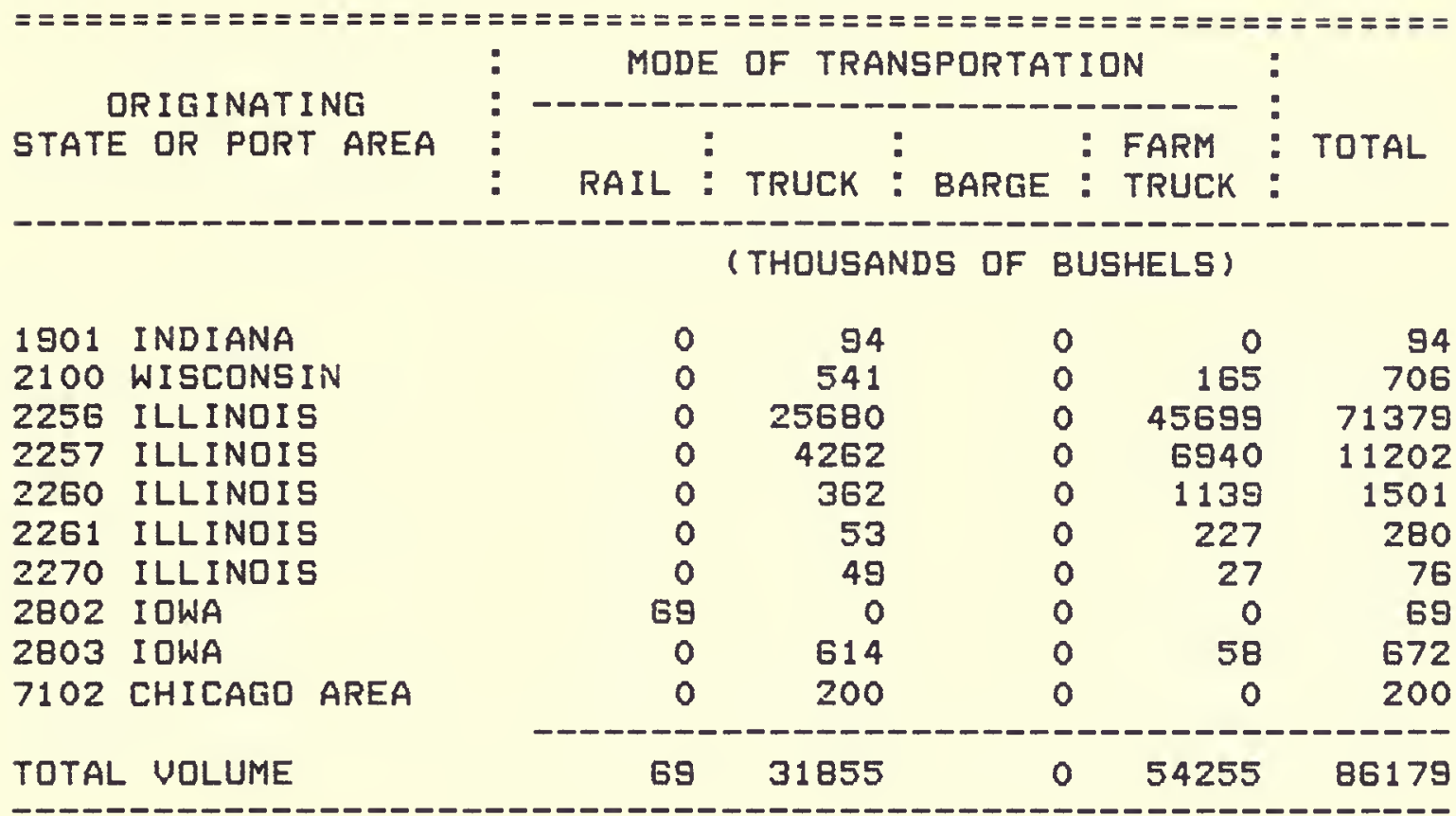

TABLE 16. 1977 SOYBEAN SHIPMENTS TO UARIOUS DESTINATIONS BY FIRMS IN AREA 2256, ILLINOIS

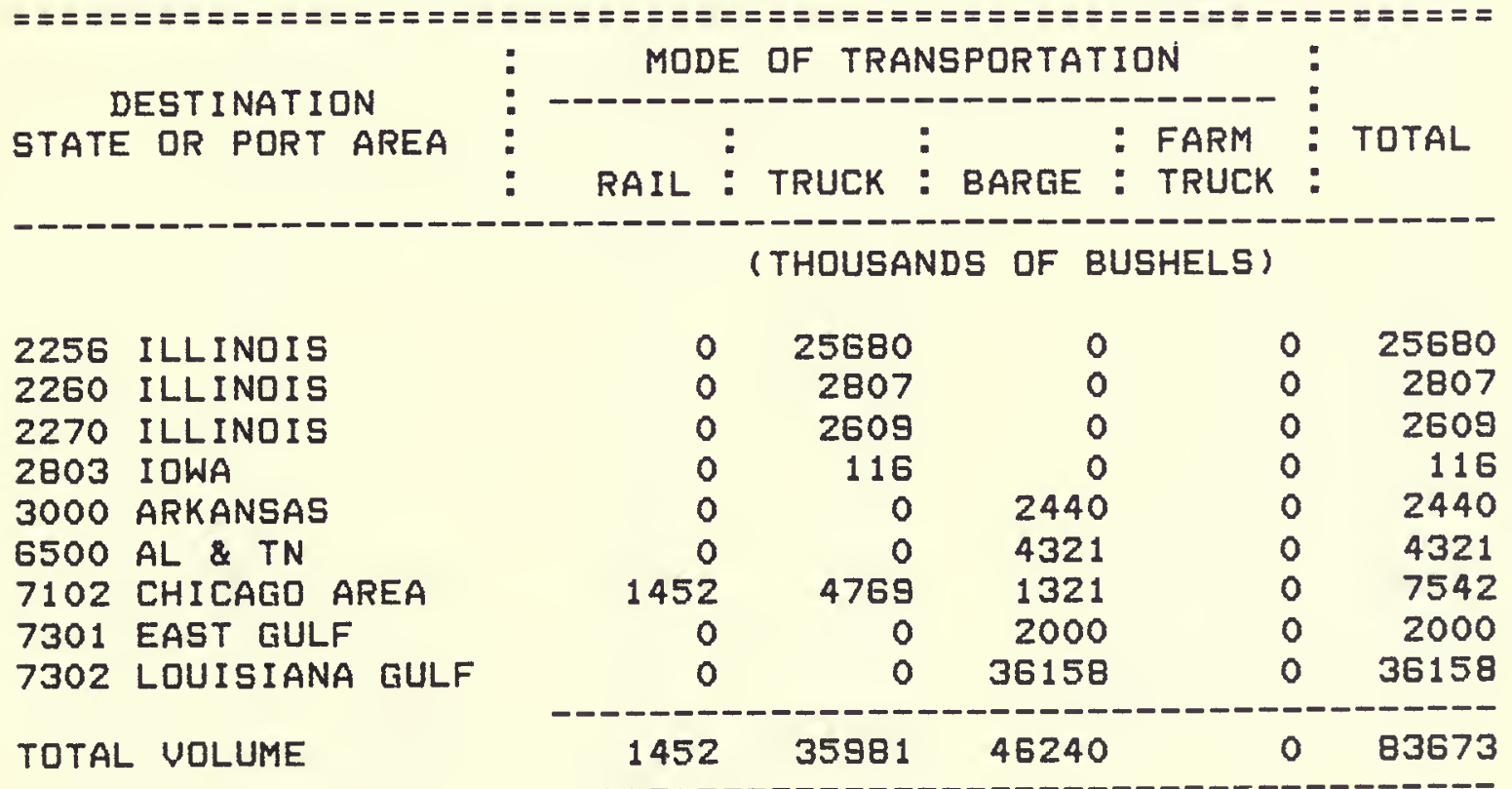


TABLE 17. 1977 SOYBEAN RECEIPTS FROM VARIOUS ORIGINS BY FIRMS IN AREA 2257, ILLINOIS

\begin{tabular}{|c|c|c|c|c|c|c|}
\hline \multirow{2}{*}{$\begin{array}{l}\text { ORIGINATING } \\
\text { STATE OR PORT AREA }\end{array}$} & \multicolumn{5}{|c|}{ MODE OF TRANSPORTATION } & \multirow[b]{2}{*}{ TOTAL } \\
\hline & RAIL & TRUCK & BARGE & & $\begin{array}{l}\text { FARM } \\
\text { TRUCK }\end{array}$ & \\
\hline & \multicolumn{5}{|c|}{ (THOUSANDS OF BUSHELS) } & \\
\hline 1901 INDIANA & 1456 & 2894 & & 0 & 1931 & 6281 \\
\hline 1902 INDIANA & 15 & 5246 & & 0 & 0 & 5261 \\
\hline 1903 IND I ANA & 164 & 0 & & 0 & 0 & 164 \\
\hline 2100 WISCONSIN & 0 & 30 & & 0 & 0 & 30 \\
\hline 2256 ILLINOIS & 0 & 0 & & 0 & 5 & 5 \\
\hline 2257 ILLINOIS & 2010 & 8972 & & 0 & 38533 & 49515 \\
\hline 2258 ILLINOIS & 512 & 971 & & 0 & 2 & 1485 \\
\hline 2260 ILLINOIS & 0 & 178 & & 0 & 19 & 197 \\
\hline 2270 ILLINOIS & 0 & 3604 & & 0 & 631 & 4235 \\
\hline OTAL VOLUME & 4157 & 21895 & & 0 & 41121 & 67173 \\
\hline
\end{tabular}

TABLE 18. 1977 SOYBEAN SHIPMENTS TO VARIOUS DESTINATIONS BY FIRMS IN AREA 2257, ILLINOIS

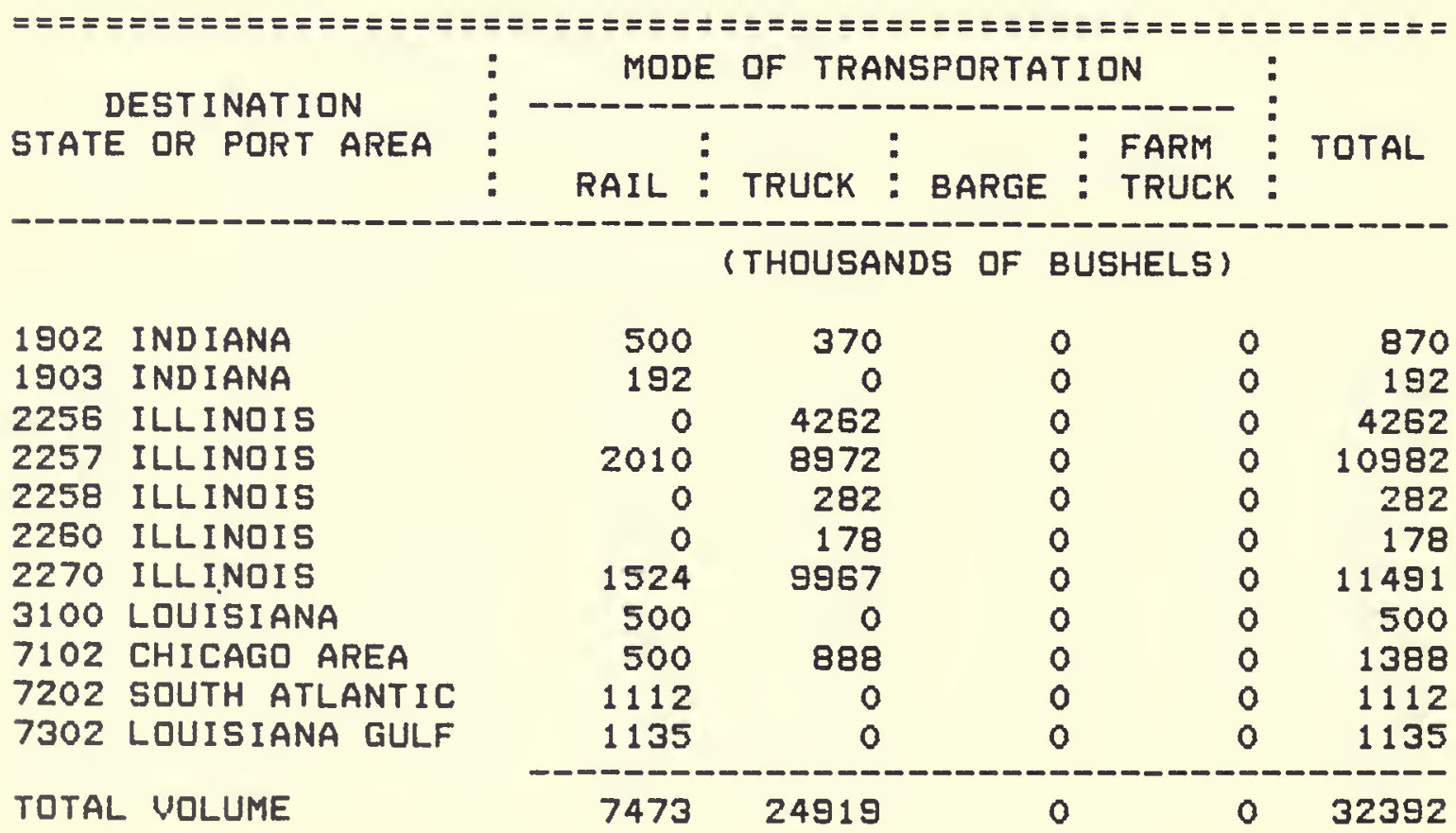


TABLE 19. 1977 SOYBEAN RECEIPTS FROM UARIOUS ORIGINS BY FIRMS IN AREA 2258, ILLINOIS

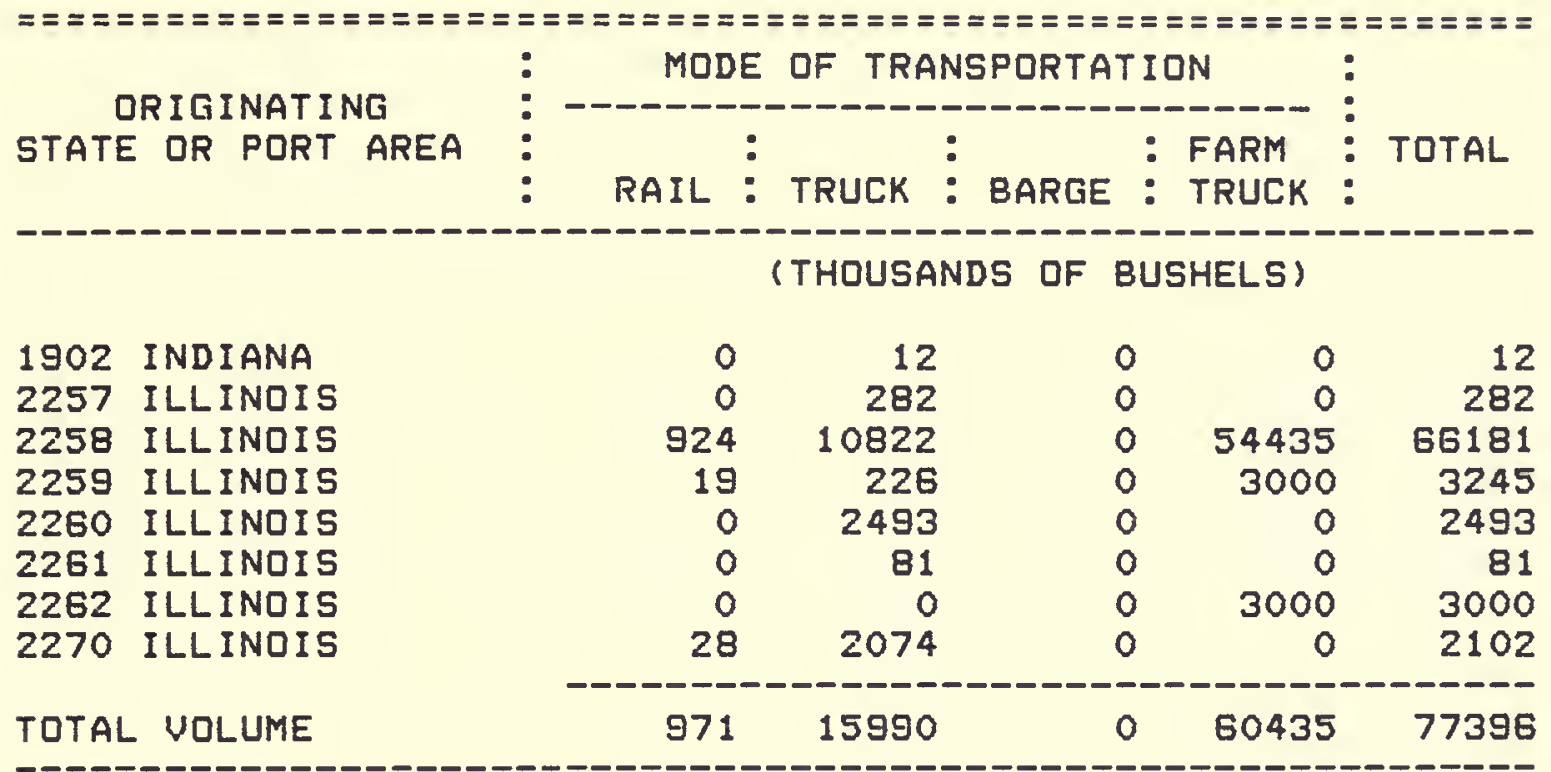

TABLE 20. 1977 SOYBEAN SHIPMENTS TO UARIOUS DESTINATIONS BY FIRMS IN AREA 2258, ILLINOIS

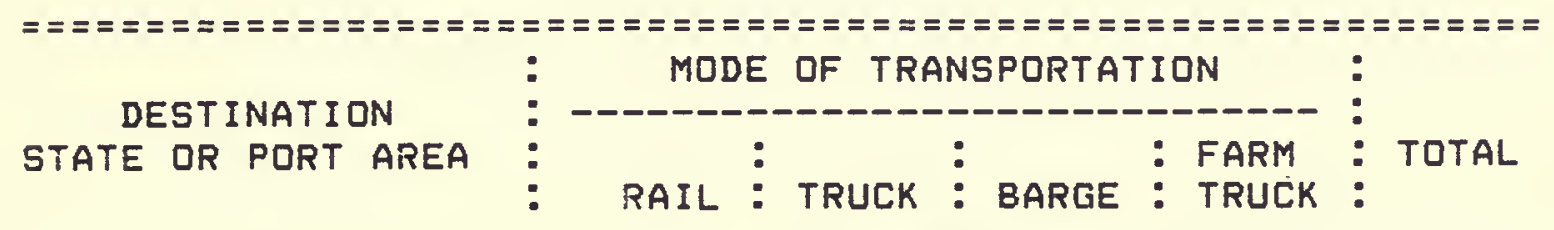

(THOUSANDS OF BUSHELS)

\begin{tabular}{|c|c|c|c|c|c|c|}
\hline 1901 & INDIANA & 165 & 0 & 0 & 0 & 165 \\
\hline 1902 & INDIANA & 645 & 0 & 0 & 0 & 645 \\
\hline 1903 & INDIANA & 0 & 5150 & 0 & 0 & 5150 \\
\hline 2257 & ILLINOIS & 512 & 971 & 0 & 0 & 1483 \\
\hline 2258 & ILLINOIS & 924 & 10822 & 0 & 0 & 11746 \\
\hline 2259 & ILLINOIS & 0 & 396 & 0 & 0 & 396 \\
\hline 2260 & ILLINOIS & 0 & 1736 & 0 & 0 & 1736 \\
\hline 2261 & ILLINOIS & 0 & 4474 & 0 & 0 & 4474 \\
\hline 2262 & ILLINOIS & 396 & 1749 & 0 & 0 & 2145 \\
\hline 2270 & ILLINOIS & 1057 & 29783 & 0 & 0 & 30840 \\
\hline 2900 & MISSDURI & 1168 & 1970 & 0 & 0 & 3138 \\
\hline 6500 & $A L \& T N$ & 110 & 0 & 0 & 0 & 110 \\
\hline 7202 & SOUTH ATLANTIC & 335 & 0 & 0 & 0 & 335 \\
\hline 7302 & LOUISIANA GULF & 647 & 0 & 0 & 0 & 647 \\
\hline TOTAL & - VOLUME & 5959 & 57051 & 0 & 0 & 63010 \\
\hline
\end{tabular}


TABLE 21. 1977 SOYBEAN RECEIPTS FROM UARIOUS ORIGINS BY FIRMS IN AREA 2259, ILLINOIS

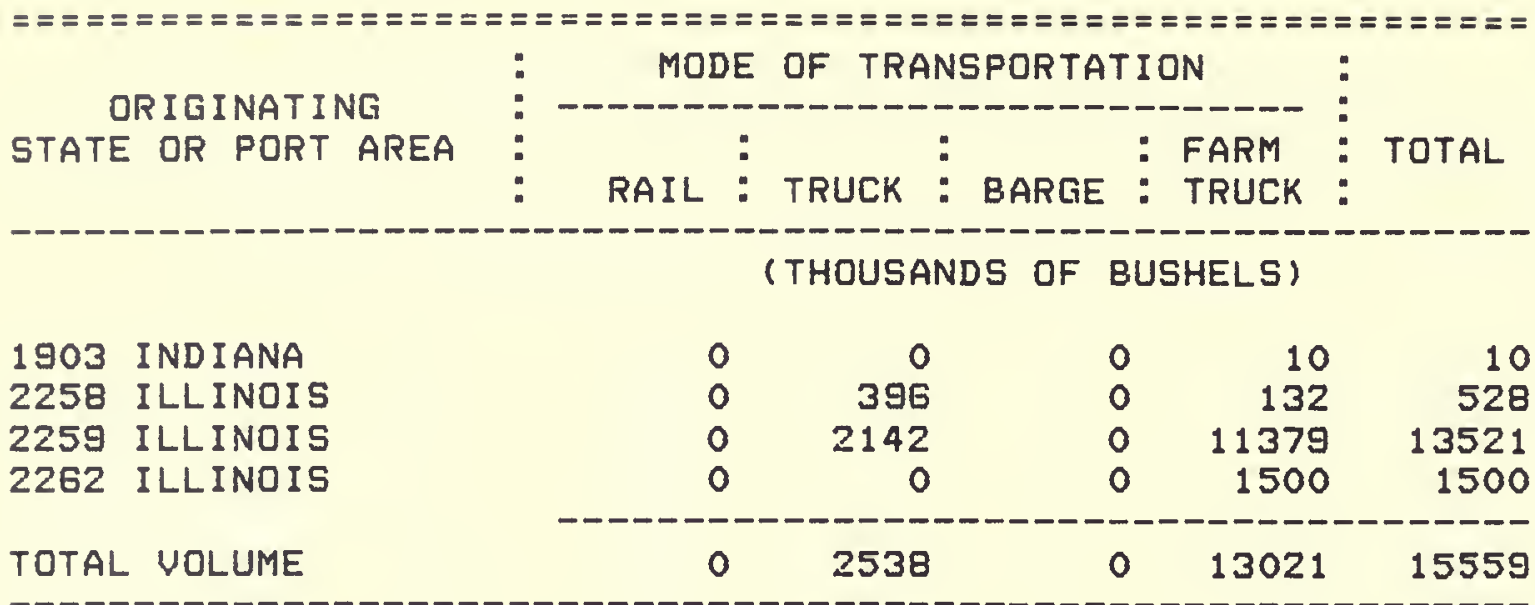

TABLE 22. 1977 SOYBEAN SHIPMENTS TO VARIOUS DESTINATIONS BY FIRMS IN AREA 2259, ILLINOIS

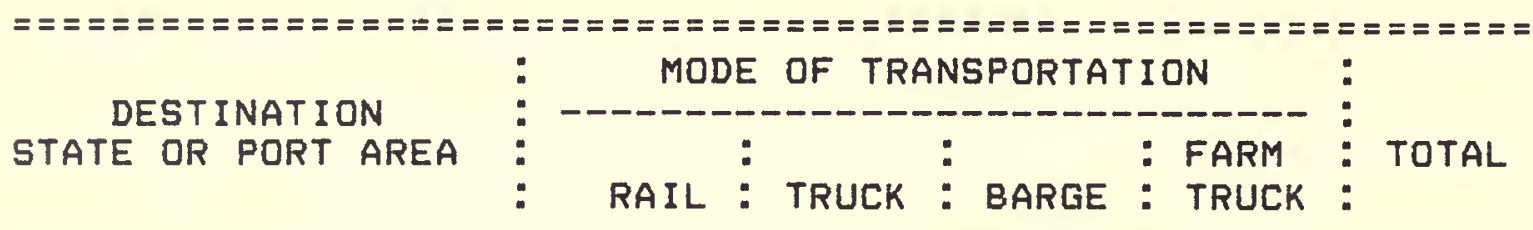

(THOUSANDS OF BUSHELS)

\begin{tabular}{|c|c|c|c|c|c|c|}
\hline 1903 & INDI ANA & 0 & 72 & 0 & 0 & 72 \\
\hline 2258 & ILLINOIS & 19 & 226 & 0 & 0 & 245 \\
\hline 2259 & ILLINOIS & 0 & 2142 & 0 & 0 & 2142 \\
\hline 2261 & ILLINOIS & 0 & 710 & 0 & 0 & 710 \\
\hline 2262 & ILLINOIS & 0 & 56 & 0 & 0 & 56 \\
\hline 2270 & ILLINOIS & 252 & 15 & 0 & 0 & 267 \\
\hline 6400 & $F L, G A \& 5 C$ & 1687 & 0 & 0 & 0 & 1687 \\
\hline 6500 & $A L \& T N$ & 5004 & 0 & 0 & 0 & 5004 \\
\hline 7301 & EAST GULF & 621 & 0 & 0 & 0 & 621 \\
\hline 7302 & LOUISIANA GULF & 0 & 0 & 3483 & 0 & 3483 \\
\hline 7303 & NO. TEXAS GULF & 320 & 0 & 0 & 0 & 320 \\
\hline ד ד & VOLUME & 7903 & 3221 & 3483 & 0 & 14607 \\
\hline
\end{tabular}


TABLE 23. 1977 SOYBEAN RECEIPTS FROM UARIOUS ORIGINS BY FIRMS IN AREA 2260, ILLINOIS

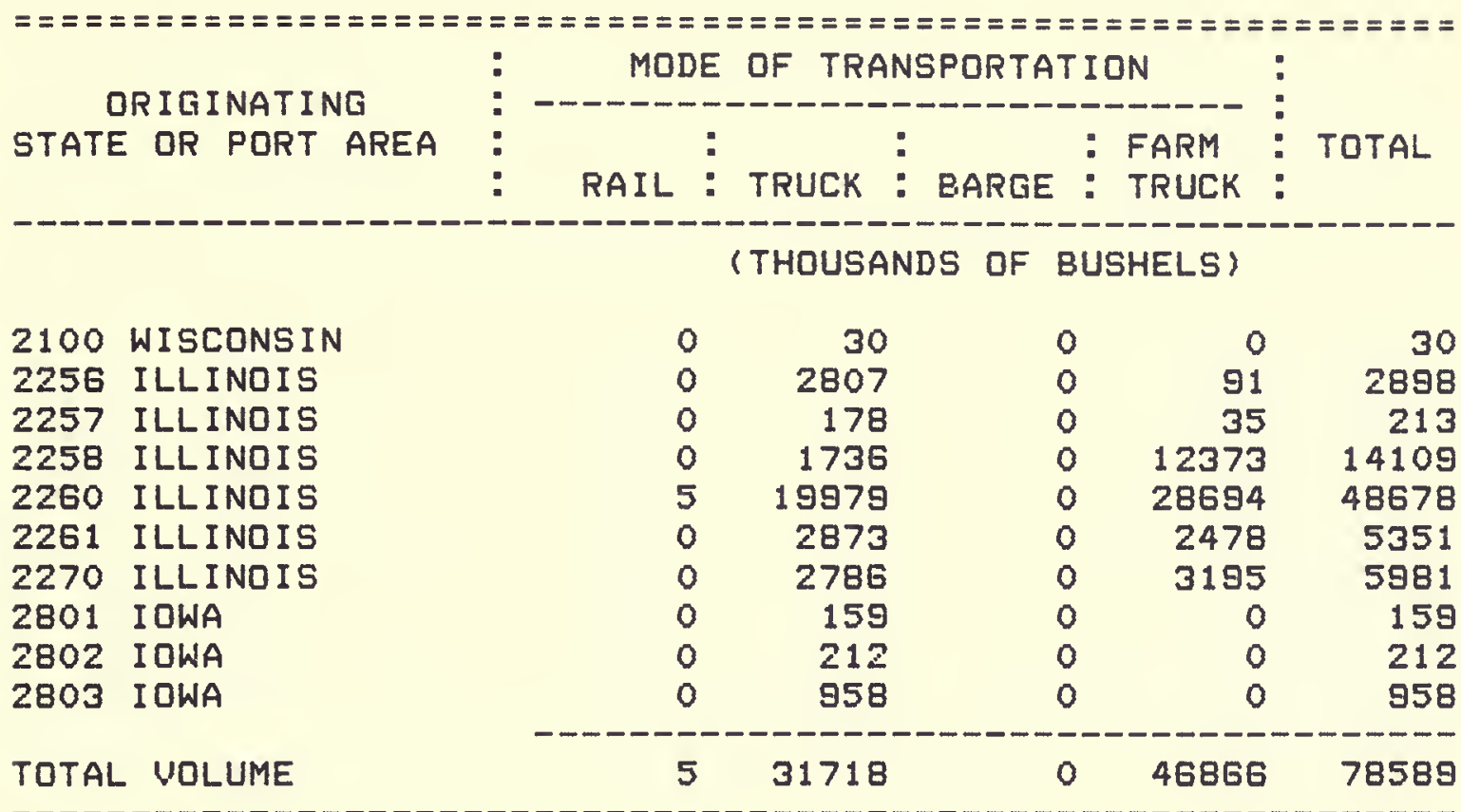

TABLE 24. 1977 SOYBEAN SHIPMENTS TO VARIOUS DESTINATIONS BY FIRMS IN AREA 2260, ILLINOIS

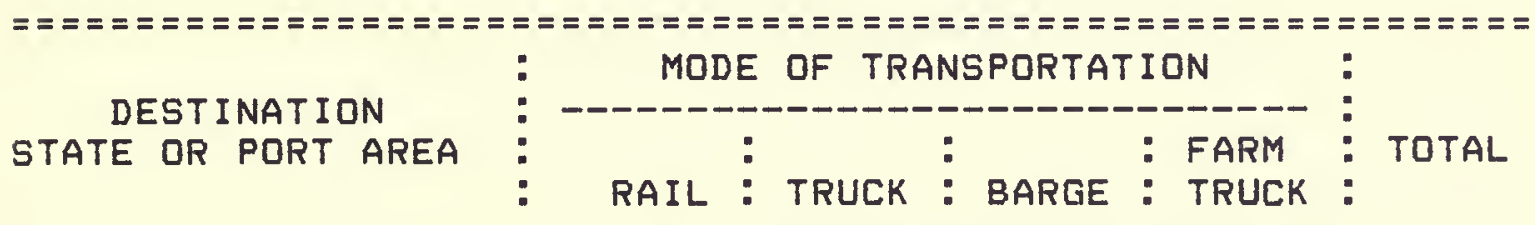

(THOUSANDS OF BUSHELS)

\begin{tabular}{|c|c|c|c|c|c|c|}
\hline 2256 & ILLINOIS & 0 & 362 & 0 & 0 & 362 \\
\hline 2257 & ILLINOIS & 0 & 178 & 0 & 0 & 178 \\
\hline 2258 & ILLINOIS & 0 & 2493 & 0 & 0 & 2493 \\
\hline 2260 & ILLINOIS & 5 & 19979 & 0 & 0 & 19984 \\
\hline 2261 & ILLINOIS & 0 & 1242 & 0 & 0 & 1242 \\
\hline 2262 & ILLINOIS & 0 & 7888 & 0 & 0 & 7888 \\
\hline 2270 & ILLINOIS & 533 & 1617 & 0 & 0 & 2150 \\
\hline 2900 & MISSOUR I & 0 & 2589 & 0 & 0 & 2589 \\
\hline 3000 & ARKANSAS & 0 & 0 & 1560 & 0 & 1560 \\
\hline 6500 & AL \& TN & 0 & 0 & 3069 & 0 & 3069 \\
\hline 7301 & EAST GULF & 0 & 0 & 6528 & 0 & 6528 \\
\hline 7302 & LOUISIANA GULF & 0 & 0 & 23614 & 0 & 23614 \\
\hline OTAI & UOLUME & 538 & 36348 & 34771 & 0 & 716 \\
\hline
\end{tabular}


TABLE 25. 1977 SOYBEAN RECEIPTS FROM VARRIDUS ORIGINS BY FIRMS IN AREA 2261, ILLINOIS

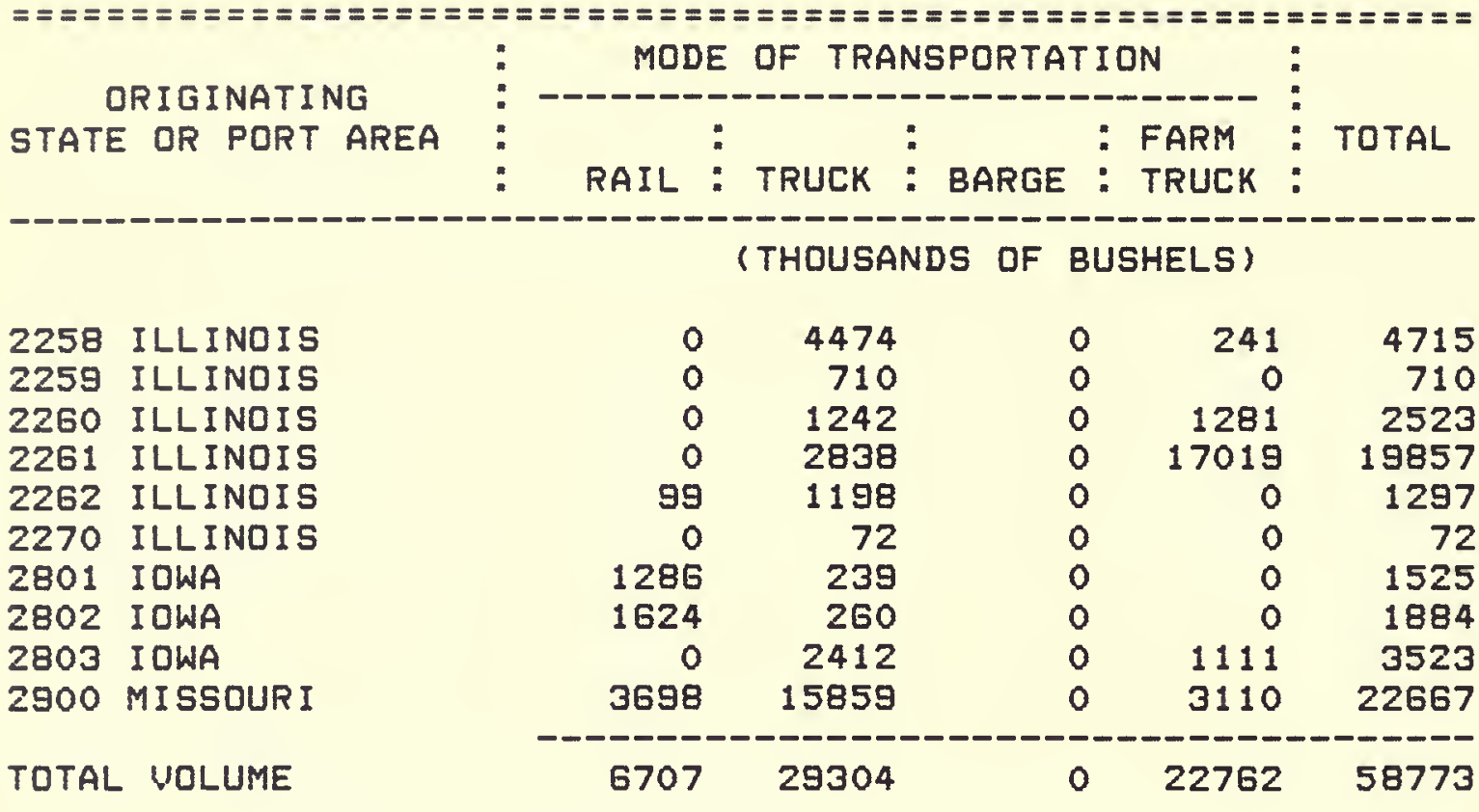

TABLE 26. 1977 SOYBEAN SHIPMENTS TO UARIOUS DESTINATIONS BY FIRMS IN AREA 2261, ILLINOIS

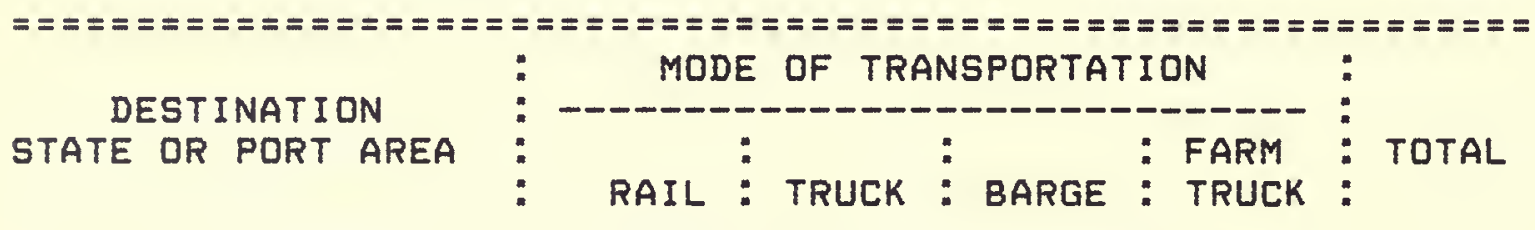

(THOUSANDS OF BUSHELS)

$\begin{array}{llrrrrr}2256 & \text { ILLINOIS } & 0 & 53 & 0 & 0 & 53 \\ 2258 & \text { ILLINDIS } & 0 & 81 & 0 & 0 & 81 \\ 2260 & \text { ILLINOIS } & 0 & 2873 & 0 & 0 & 2873 \\ 2261 & \text { ILLINDIS } & 0 & 2838 & 0 & 0 & 2838 \\ 2262 & \text { ILLINOIS } & 136 & 1520 & 0 & 0 & 1656 \\ 2270 & \text { ILLINOIS } & 1416 & 180 & 0 & 0 & 1596 \\ 2803 & \text { IOWA } & 0 & 4 & 0 & 0 & 4 \\ 7302 \text { LOUISIANA GULF } & 0 & 0 & 13042 & 0 & 13042 \\ \text { TOTAL VOLUME } & -0-1552 & 7549 & 13042 & 0 & 22143\end{array}$


TABLE 27. 1977 SOYBEAN RECEIPTS FROM UARIOUS ORIGINS BY FIRMS IN AREA 2262, ILLINOIS

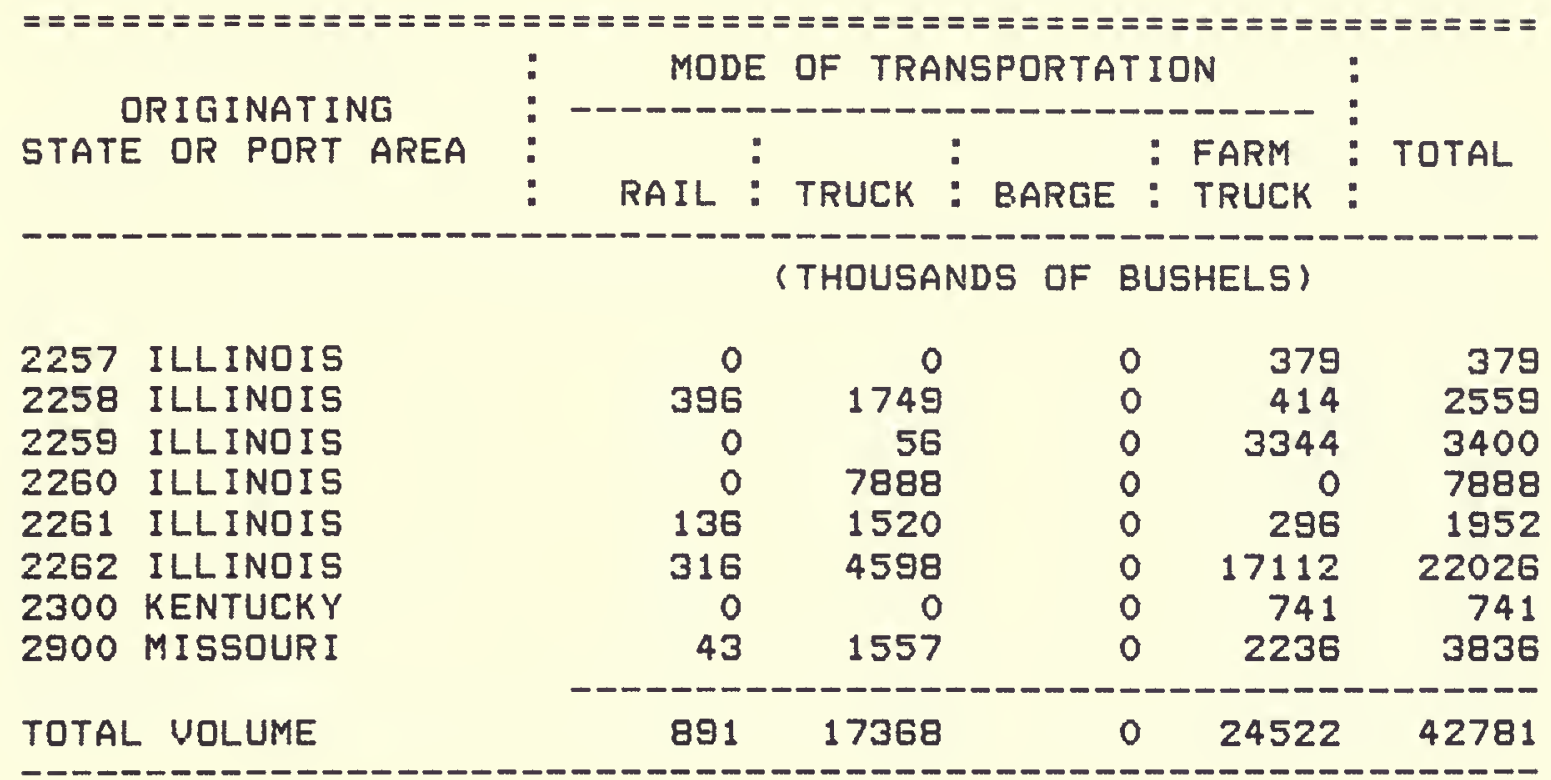

TABLE 28. 1977 SOYBEAN SHIPMENTS TO UARIOUS DESTINATIONS BY FIRMS IN AREA 2262, ILLINOIS

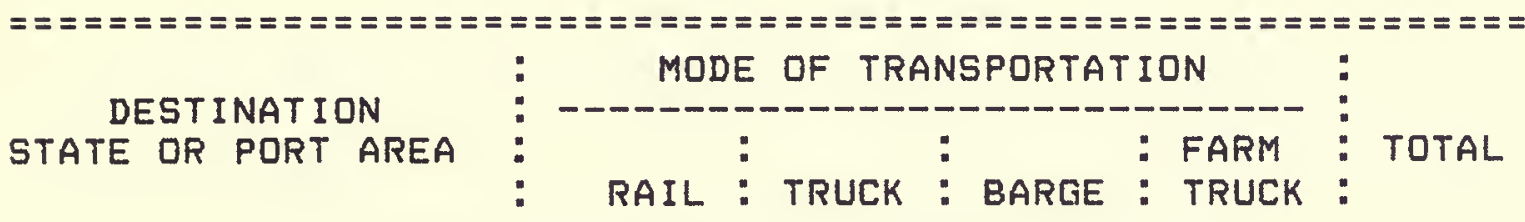

(THOUSANDS OF BUSHELS)

\begin{tabular}{|c|c|c|c|c|c|c|}
\hline 2261 & ILLINOIS & 99 & 1198 & 0 & 0 & 1297 \\
\hline 2262 & ILLINOIS & 316 & 4598 & 0 & 0 & 4914 \\
\hline 2270 & ILLINOIS & 0 & 375 & 0 & 0 & 375 \\
\hline 2300 & KENTUCKY & 27 & 0 & 0 & 0 & 27 \\
\hline 2900 & MISSDUR I & 0 & 18 & 0 & 0 & 18 \\
\hline 3100 & LOUISIANA & 9 & 0 & 0 & 0 & \\
\hline 5400 & $F L, G A \& S C$ & 250 & 0 & 0 & 0 & 250 \\
\hline 6500 & $A L \& T N$ & 7709 & 0 & 3150 & 0 & 10855 \\
\hline 7301 & EAST GULF & 685 & 0 & 1400 & 0 & 2085 \\
\hline 7302 & LOUISIANA GULF & 305 & 0 & 21323 & 0 & 21628 \\
\hline DTAL & UOLUME & 9400 & 6189 & 25873 & 0 & $414 G$ \\
\hline
\end{tabular}


TABLE 29. 1977 SOYBEAN RECEIPTS FROM UARIOUS ORIGINS BY FIRMS IN AREA 2270, ILLINOIS

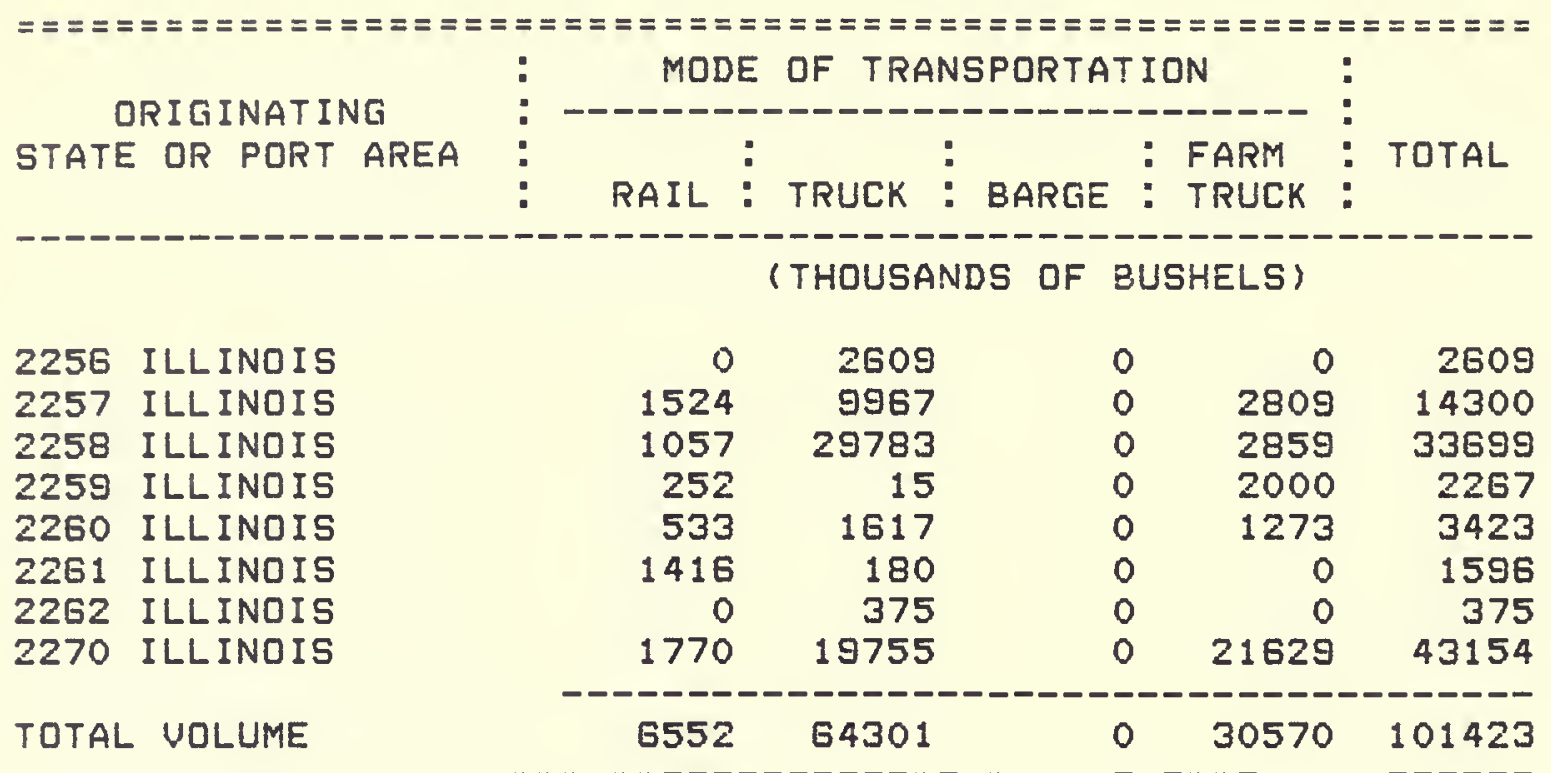

TABLE 30. 1977 SOYBEAN SHIPMENTS TO VARIOUS DESTINATIONS BY FIRMS IN AREA 2270 , ILLINOIS

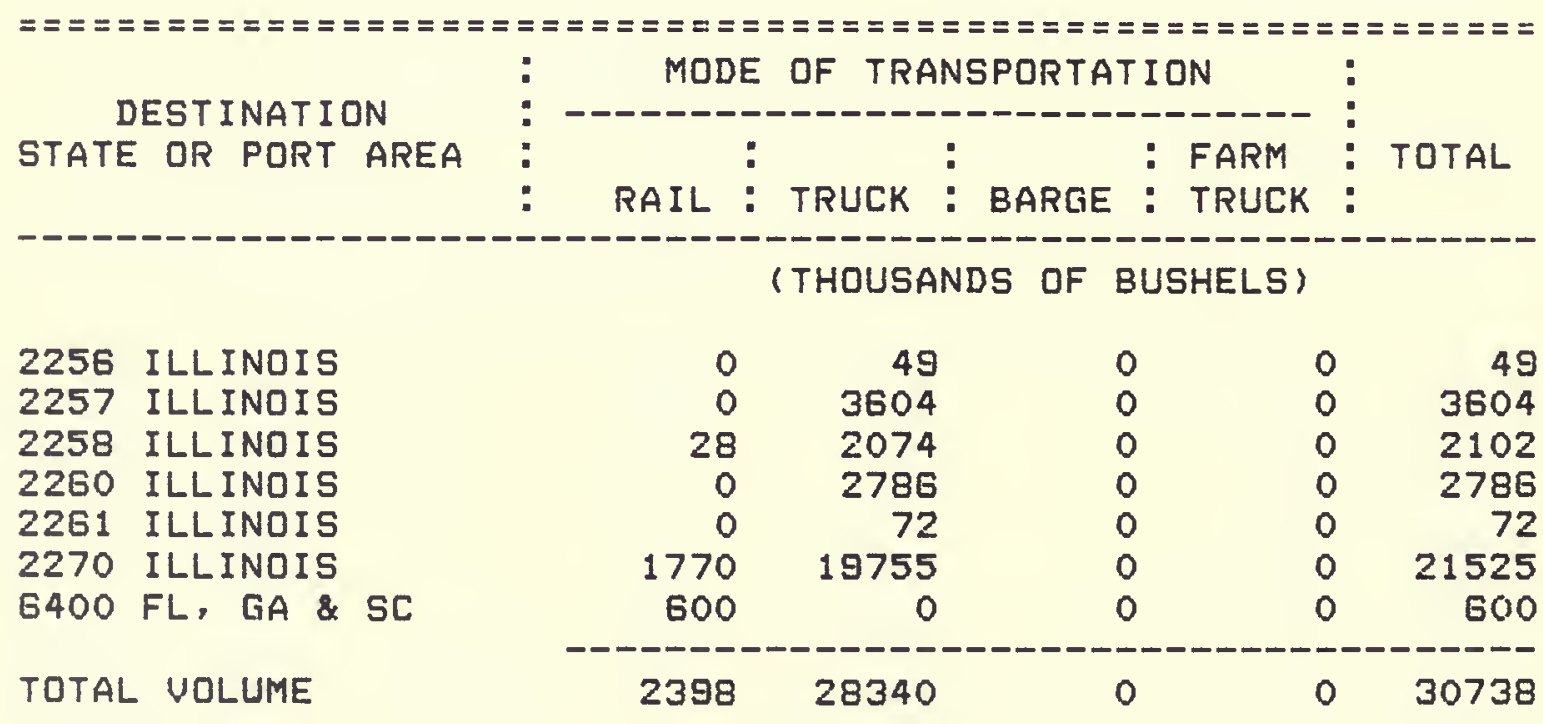


TABLE 31. 1977 SOYBEAN RECEIPTS FROM UARIOUS ORIGINS BY FIRMS IN AREA 1901, INDIANA

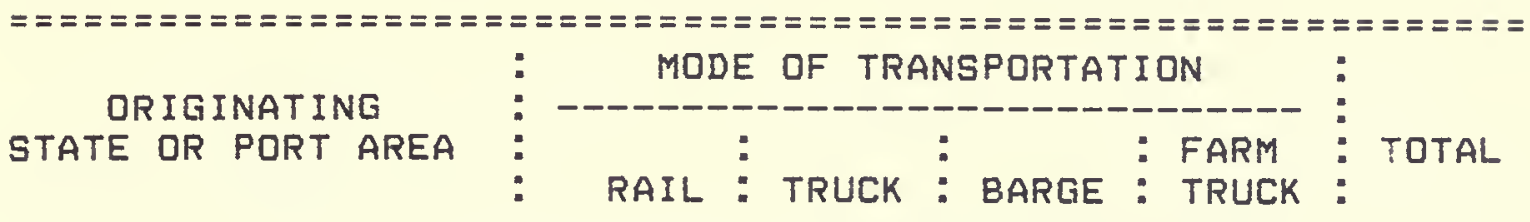

(THOUSANDS OF BUSHELS)

\begin{tabular}{|c|c|c|c|c|c|}
\hline 1825 DHIO & 0 & 62 & 0 & 0 & 62 \\
\hline 1850 OHIO & 0 & 4364 & 0 & 0 & 4364 \\
\hline 1901 INDIANA & 73 & 14828 & 0 & 59771 & 74672 \\
\hline 1902 INDIANA & 0 & 3153 & 0 & 11758 & 14911 \\
\hline 2000 MICHIGAN & 0 & 501 & 0 & 0 & 501 \\
\hline 2258 ILLINOIS & 165 & 0 & 0 & 0 & 165 \\
\hline 102 CHICAGD AREA & 393 & 0 & 0 & 0 & 393 \\
\hline L VOLUME & 631 & 22908 & 0 & 71529 & 9506 \\
\hline
\end{tabular}

TABLE 32. 1977 SOYBEAN SHIPMENTS TO UARIOUS DESTINATIONS BY FIRMS IN AREA 1901, INDIANA

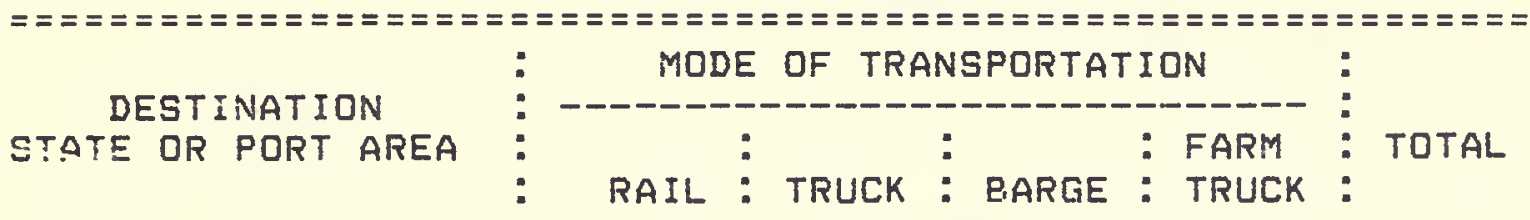

(THOUSANDS OF BUSHELS)

\begin{tabular}{|c|c|c|c|c|c|c|}
\hline 1901 & IND I ANA & 73 & 14828 & 0 & 0 & 14901 \\
\hline 1902 & IND I ANA & 0 & 11242 & 0 & 0 & 11242 \\
\hline 2256 & ILLINOIS & 0 & 94 & 0 & 0 & 94 \\
\hline 2257 & ILLINOIS & 1456 & 2894 & 0 & 0 & 4350 \\
\hline 2300 & KENTUCKY & 0 & 44 & 0 & 0 & 44 \\
\hline 7102 & CHICAGD AREA & 0 & 9538 & 0 & 0 & 9538 \\
\hline 7103 & TOLEDO AREA & 350 & 1774 & 0 & 0 & 2124 \\
\hline 7202 & SOUTH ATLANTIC & 4727 & 0 & 0 & 0 & 4727 \\
\hline 7301 & EAST GULF & 212 & 0 & 0 & 0 & 212 \\
\hline TOTAL & - VOLUME & 6818 & 40414 & 0 & 0 & 4723 \\
\hline
\end{tabular}


TABLE 33. 1977 SOYBEAN RECEIPTS FROM UARIOUS ORIGINS BY FIRMS IN AREA 1902, INDIANA

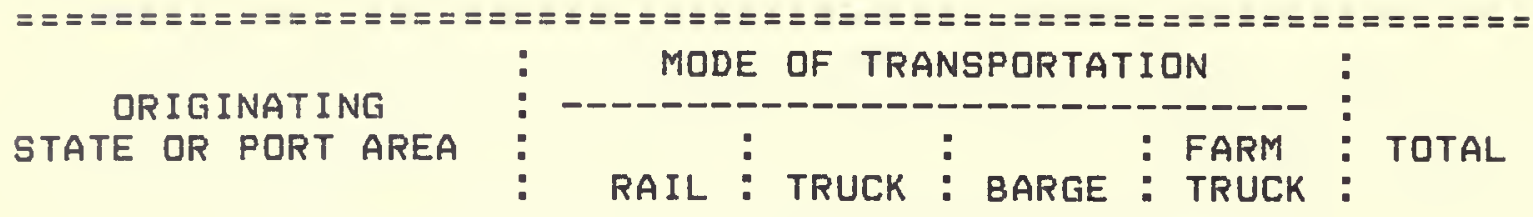

(THOUSANDS OF BUSHELS)

$\begin{array}{llrrrrr}1825 & \text { OHIO } & 0 & 22 & 0 & 0 & 22 \\ 1850 & \text { OHIO } & 0 & 189 & 0 & 0 & 189 \\ 1901 & \text { INDIANA } & 0 & 11242 & 0 & 11758 & 23000 \\ 1902 & \text { INDIANA } & 0 & 22758 & 0 & 51848 & 74606 \\ 1903 & \text { INDIANA } & 0 & 522 & 0 & 618 & 1140 \\ 2256 & \text { ILLINOIS } & 0 & 0 & 0 & 464 & 464 \\ 2257 & \text { ILLINOIS } & 500 & 370 & 0 & 171 & 1041 \\ 2258 & \text { ILLINOIS } & 645 & 0 & 0 & 0 & 645 \\ \text { TOTAL UOLUME } & --0-145 & 35103 & 0 & 64859 & 101107\end{array}$

TABLE 34. 1977 SOYBEAN SHIPMENTS TO UARIOUS DESTINATIONS BY FIRMS IN AREA 1902, INDIANA

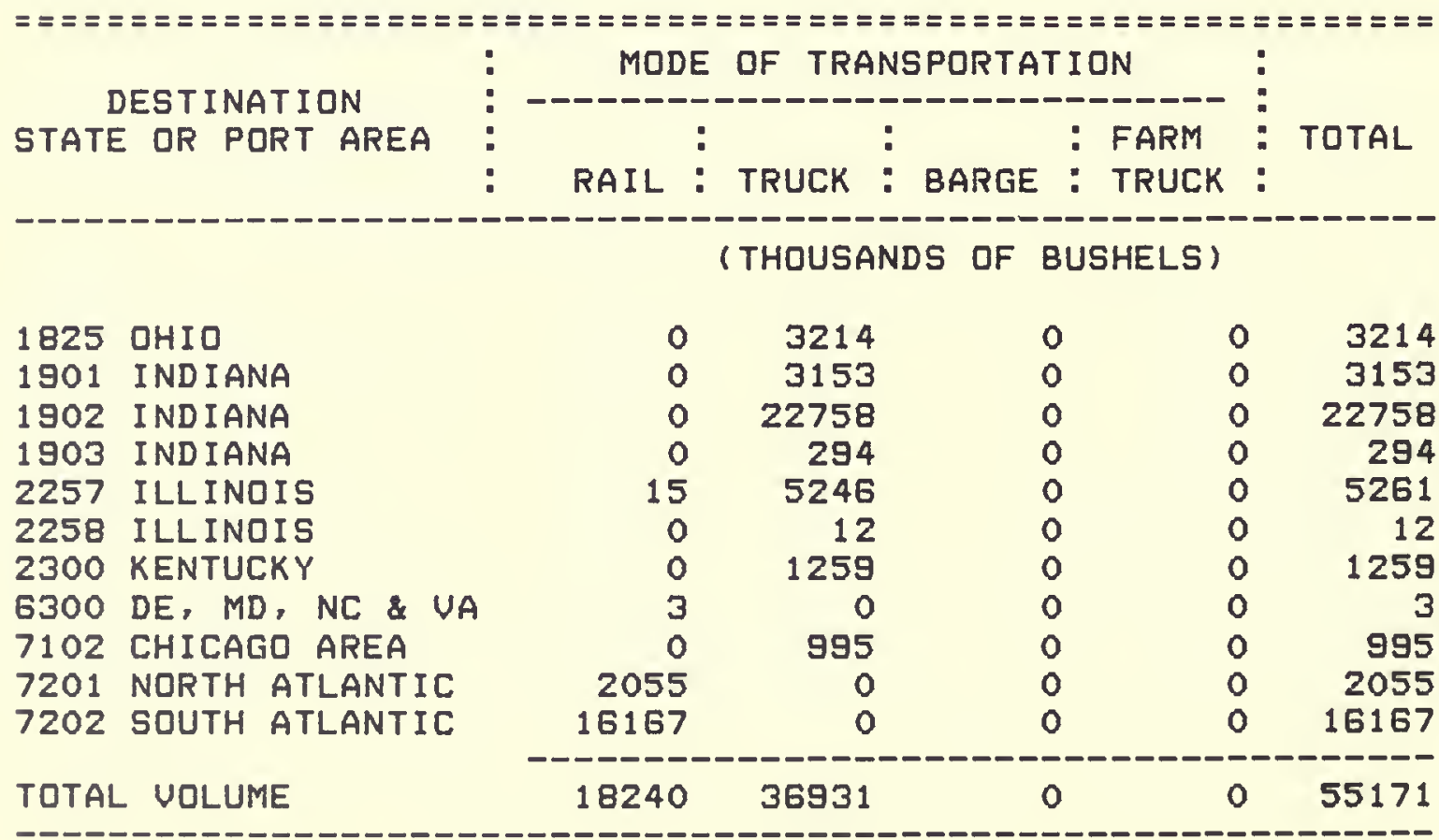


TABLE 35. 1977 SQYBEAN RECEIPTS FROM UARIQUS ORIGINS BY FIRMS IN AREA 1903, INDIANA

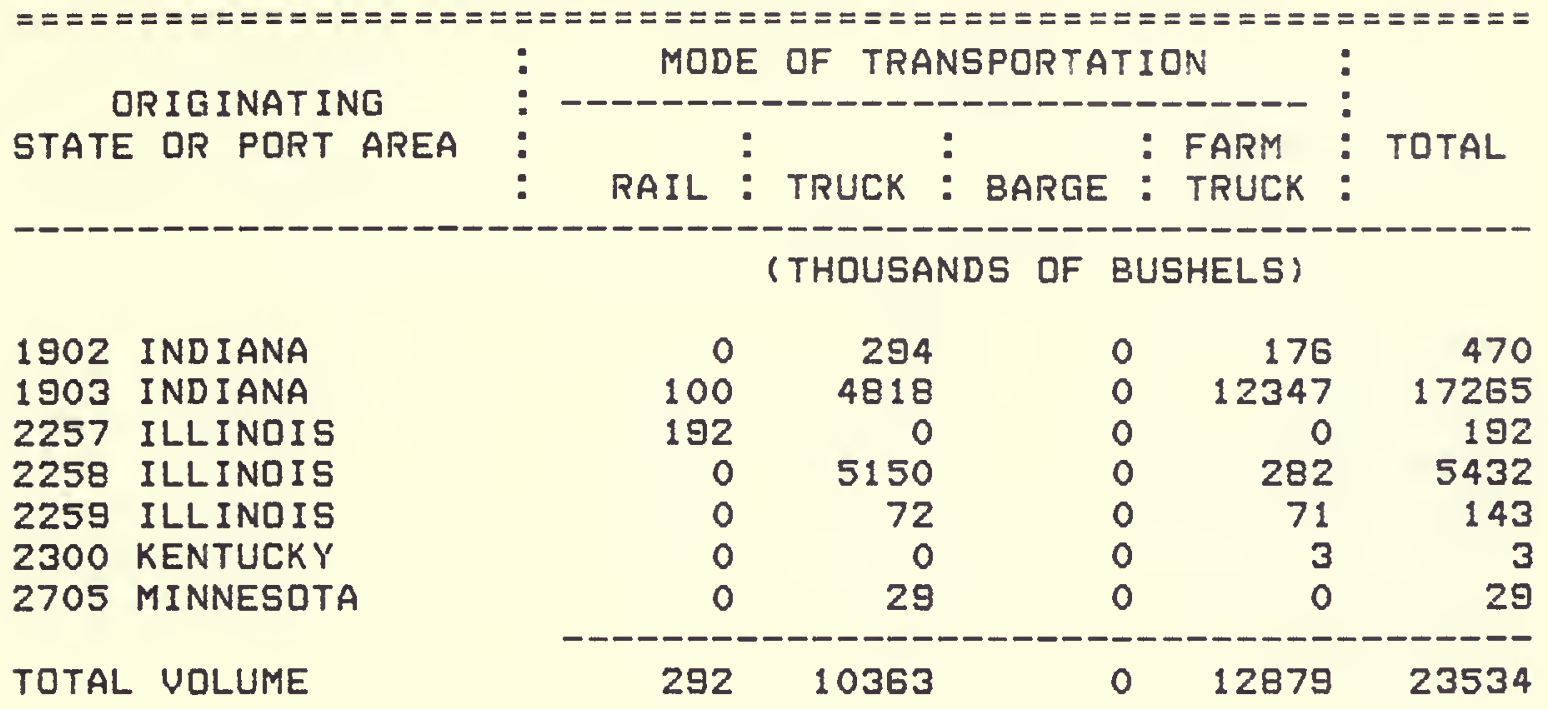

TABLE 36. 1977 SOYBEAN SHIPMENTS TO UARIDUS DESTINATIONS BY FIRMS IN AREA 1903, INDIANA

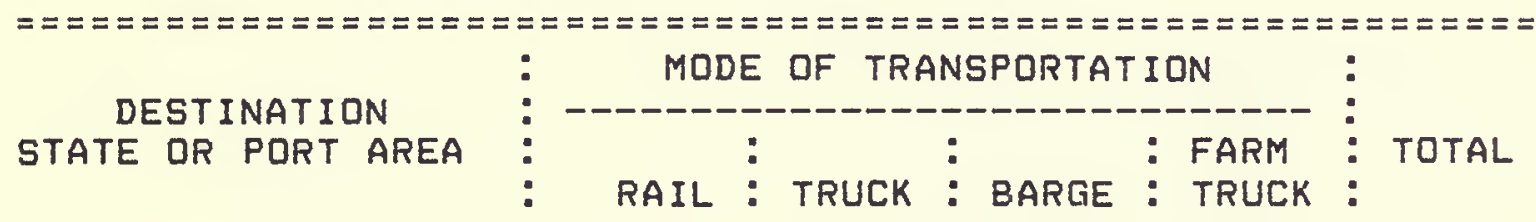

(THOUSANDS OF BUSHELS)

\begin{tabular}{|c|c|c|c|c|c|c|}
\hline 1825 & QHIO & 0 & 722 & 0 & 0 & 722 \\
\hline 1902 & IND IANA & 0 & 522 & 0 & 0 & 522 \\
\hline 1903 & IND I ANA & 100 & 4818 & 0 & 0 & 4918 \\
\hline 2257 & ILLINOIS & 164 & 0 & 0 & 0 & 164 \\
\hline 2300 & KENTUCKY & 2684 & 5495 & 0 & 0 & 8179 \\
\hline 6300 & $D E, M D, N C$ \& UA & 316 & 0 & 0 & 0 & 316 \\
\hline 6400 & $F L, G A \& S C$ & 3451 & 0 & 0 & 0 & 3451 \\
\hline 6500 & $A L \& T N$ & 1272 & 0 & 475 & 0 & 1747 \\
\hline 7301 & EAST GULF & 329 & 0 & 87 & 0 & $41 G$ \\
\hline 7302 & LOUISIANA GULF & 50 & 0 & 8033 & 0 & 8083 \\
\hline 8 & UOLUME & 8366 & 11557 & 8595 & 0 & 28518 \\
\hline
\end{tabular}


TABLE 37. 1977 SOYBEAN RECEIPTS FROM UARIOUS ORIGINS BY FIRMS IN AREA 2801, IOWA

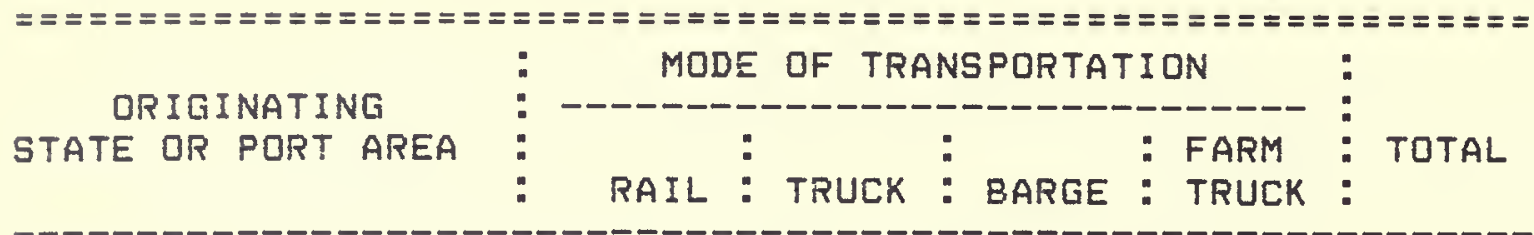

(THOUSANDS OF BUSHELS)

\begin{tabular}{|c|c|c|c|c|c|}
\hline 2703 MINNESOTA & 0 & 4097 & 0 & 0 & 4097 \\
\hline 2801 IOWA & 569 & 29347 & 0 & 107854 & 137770 \\
\hline 2802 IOWA & 0 & 423 & 0 & 0 & 423 \\
\hline 3300 SOUTH DAKDTA & 1573 & $4 \mathrm{G} 2 \mathrm{G}$ & 0 & 0 & 6199 \\
\hline $600 \mathrm{KS} \& \mathrm{NE}$ & 503 & 1426 & 0 & 5370 & 7299 \\
\hline VOL & 2645 & 39919 & 0 & 113224 & 1557 \\
\hline
\end{tabular}

TABLE 38. 1977 SOYBEAN SHIPMENTS TO VARIOUS DESTINATIONS BY FIRMS IN AREA 2801, IOWA

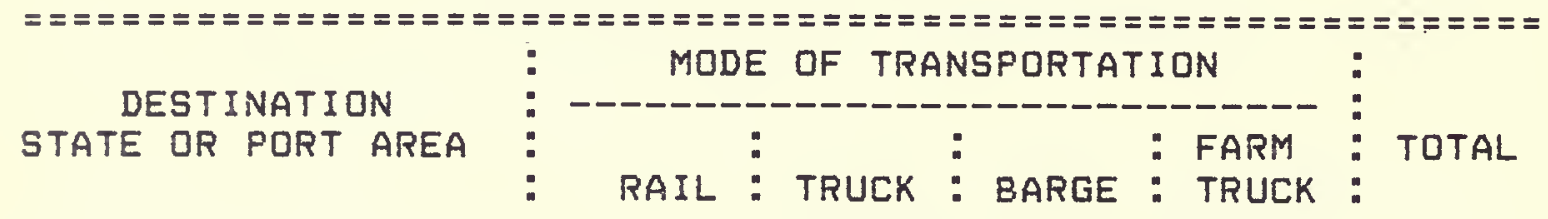

\begin{tabular}{|c|c|c|c|c|c|c|}
\hline \multirow[b]{2}{*}{2260} & \multirow[b]{2}{*}{ ILLINOIS } & \multicolumn{5}{|c|}{ (THOUSANDS OF BUSHELS) } \\
\hline & & 0 & 159 & 0 & 0 & 159 \\
\hline 2261 & ILLINOIS & 1286 & 239 & 0 & 0 & 1525 \\
\hline 2703 & MINNESOTA & 99 & 4287 & 0 & 0 & 4386 \\
\hline 2705 & MINNESOTA & 0 & 3038 & 0 & 0 & 3038 \\
\hline 2801 & IOWA & 569 & 29347 & 0 & 0 & 29916 \\
\hline 2802 & IOWA & 1938 & 14928 & 0 & 0 & 16866 \\
\hline 2803 & IOWA & 790 & 1468 & 0 & 0 & 2258 \\
\hline 2900 & MISSOURI & 1152 & 1067 & 0 & 0 & 2219 \\
\hline 3100 & LOUISIANA & 109 & 0 & 0 & 0 & 109 \\
\hline 6600 & $K S \& N E$ & 168 & 8728 & 0 & 0 & 8896 \\
\hline 7102 & CHICAGO AREA & 2040 & 0 & 0 & 0 & 2040 \\
\hline 7202 & SOUTH ATLANTIC & 377 & 0 & 0 & 0 & 377 \\
\hline 7301 & EAST GULF & 2338 & 0 & 0 & 0 & 2338 \\
\hline 7302 & LOUISIANA GULF & 12260 & 0 & 848 & 0 & 13108 \\
\hline 7303 & NO. TEXAS GULF & 4150 & 0 & 0 & 0 & 4150 \\
\hline 7403 & CALIFORNIA & 295 & 0 & 0 & 0 & 295 \\
\hline TOTAL & VOLUM & 27571 & 63261 & 848 & 0 & 91680 \\
\hline
\end{tabular}


TABLE 39. 1977 SOYBEAN RECEIPTS FROM VARIDUS DRIGINS BY FIRMS IN AREA 2802, IDWA

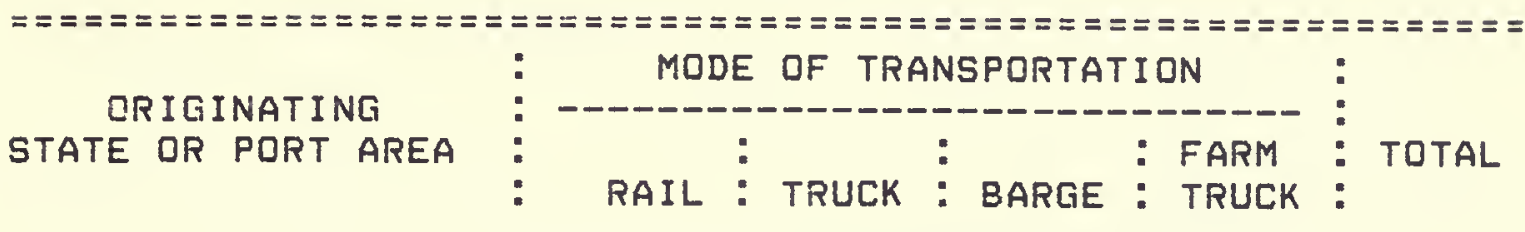

(THOUSANDS DF BUSHELS)

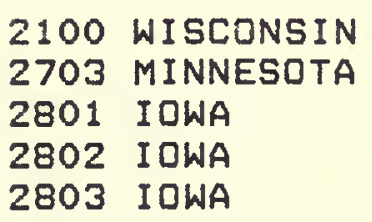

TOTAL VOLUME

\begin{tabular}{rrrrr}
0 & 156 & 0 & 0 & 156 \\
929 & 413 & 0 & 0 & 1342 \\
1938 & 14928 & 0 & 0 & 16866 \\
2925 & 50373 & 0 & 82683 & 135981 \\
0 & 2218 & 0 & 0 & 2218 \\
\hline 5792 & 68088 & 0 & 82683 & 156563
\end{tabular}

TABLE 40. 1977 SOYBEAN SHIPMENTS TD UARIDUS DESTINATIONS BY FIRMS IN AREA 2802, IOWA

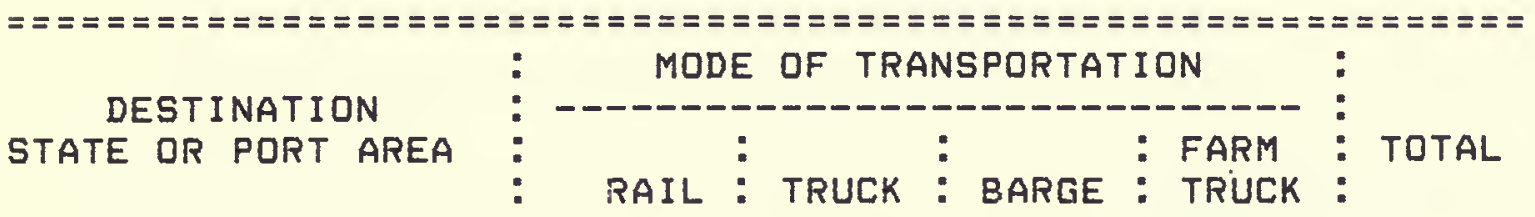

(THOUSANDS OF BUSHELS)

\begin{tabular}{|c|c|c|c|c|c|c|}
\hline 2256 & ILLINOIS & 69 & 0 & 0 & 0 & 69 \\
\hline 2260 & ILLINOIS & 0 & 212 & 0 & 0 & 212 \\
\hline 2261 & ILLINOIS & 1624 & 260 & 0 & 0 & 1884 \\
\hline 2703 & MINNESOTA & 0 & 1527 & 0 & 0 & 1527 \\
\hline 2705 & MINNESOTA & 0 & 2000 & 0 & 0 & 2000 \\
\hline 2801 & IDWA & 0 & 423 & 0 & 0 & 423 \\
\hline 2802 & IDWA & 2925 & 50373 & 0 & 0 & 53298 \\
\hline 2803 & I OWA & 3603 & 6343 & 0 & 0 & 9946 \\
\hline 2900 & MISSOUR I & 517 & 384 & 0 & 0 & 901 \\
\hline 6600 & KS \& NE & 0 & 29 & 0 & 0 & 29 \\
\hline 7102 & CHICAGD AREA & 624 & 194 & 0 & 0 & 818 \\
\hline 7202 & SOUTH ATLANTIC & 52 & 0 & 0 & 0 & 52 \\
\hline 7301 & EAST GULF & 3782 & 0 & 0 & 0 & 3782 \\
\hline 7302 & LOUISIANA GULF & 6208 & 0 & 0 & 0 & 6208 \\
\hline 7303 & NO. TEXAS GULF & 1876 & 0 & 0 & 0 & 1876 \\
\hline $\mathrm{AL}$ & VDLUME & 21280 & 61745 & 0 & 0 & 83025 \\
\hline
\end{tabular}


TABLE 41. 1977 SOYBEAN RECEIPTS FROM VARIOUS ORIGINS $8 Y$ FIRMS IN AREA 2803, IOWA

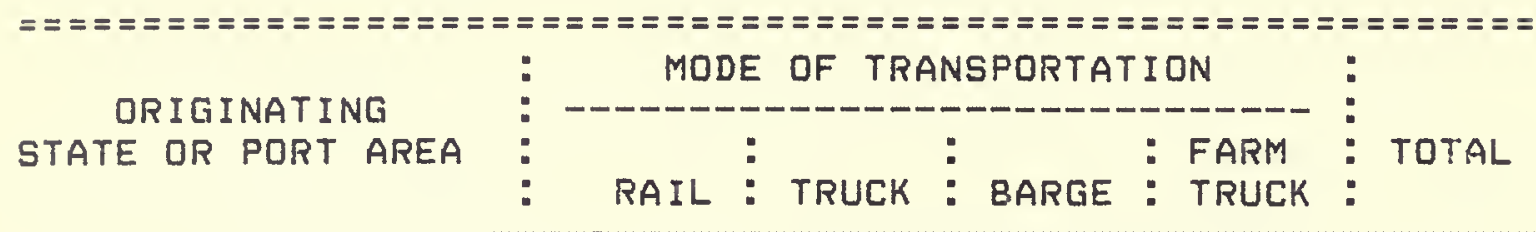

(THOUSANDS OF BUSHELS)

\begin{tabular}{llrrrrr}
2100 & WISCONSIN & 0 & 132 & 0 & 0 & 132 \\
2256 & ILLINOIS & 0 & 116 & 0 & 0 & 116 \\
2261 & ILLINOIS & 0 & 4 & 0 & 0 & 4 \\
2703 MINNESOTA & 18 & 331 & 0 & 0 & 349 \\
2801 & IOWA & 790 & 1468 & 0 & 0 & 2258 \\
2802 & IOWA & 3603 & 6343 & 0 & 0 & 9946 \\
2803 & IOWA & 2440 & 43587 & 0 & 45025 & 91052 \\
\multicolumn{1}{r}{ TOTAL WOLUME } & --19851 & 51981 & 0 & 45025 & 103857
\end{tabular}

TABLE 42. 1977 SOYBEAN SHIPMENTS TO UARIOUS DESTINATIONS BY FIRMS IN AREA 2803, IDWA

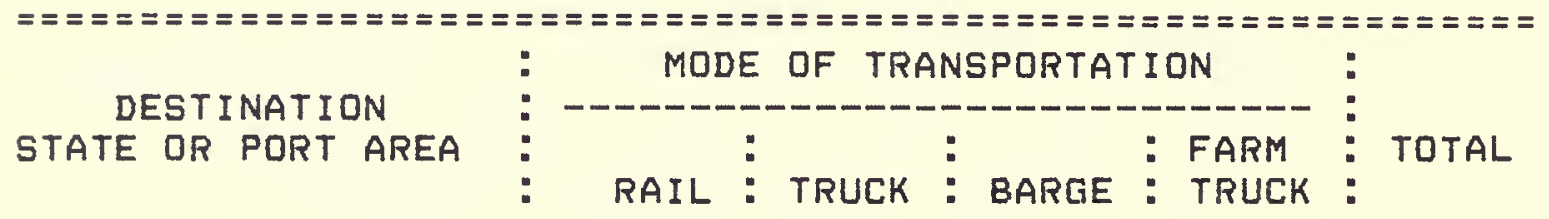

(THOUSANDS OF BUSHELS)

\begin{tabular}{|c|c|c|c|c|c|c|}
\hline 2100 & WISCONSIN & 0 & 946 & 0 & 0 & 946 \\
\hline 2256 & ILLINOIS & 0 & G14 & 0 & 0 & 614 \\
\hline 2260 & ILLINOIS & 0 & 958 & 0 & 0 & 958 \\
\hline 2261 & ILLINOIS & 0 & 2412 & 0 & 0 & 2412 \\
\hline 2705 & MINNESOTA & 0 & 150 & 0 & 0 & 150 \\
\hline 2802 & IOWA & 0 & 2218 & 0 & 0 & 2218 \\
\hline 2803 & IDWA & 2440 & 43587 & 0 & 0 & 46027 \\
\hline 2900 & MISSOURI & 0 & 534 & 0 & 0 & 534 \\
\hline 5500 & $A L \& T N$ & 0 & 0 & 587 & 0 & 587 \\
\hline 7102 & CHICAGD AREA & 0 & 447 & 0 & 0 & 447 \\
\hline 7301 & EAST GULF & 88 & 0 & 403 & 0 & 491 \\
\hline 7302 & LOUISIANA GULF & 341 & 0 & 28469 & 0 & 28810 \\
\hline 7303 & NO. TEXAS GULF & 101 & 0 & 0 & 0 & 101 \\
\hline AL & UOLUM & 2970 & 51866 & 29459 & 0 & 84295 \\
\hline
\end{tabular}


TABLE 43. 1977 SOYBEAN RECEIPTS FROM VARIOUS ORIGINS BY FIRMS IN AREA 2300, KENTUCKY

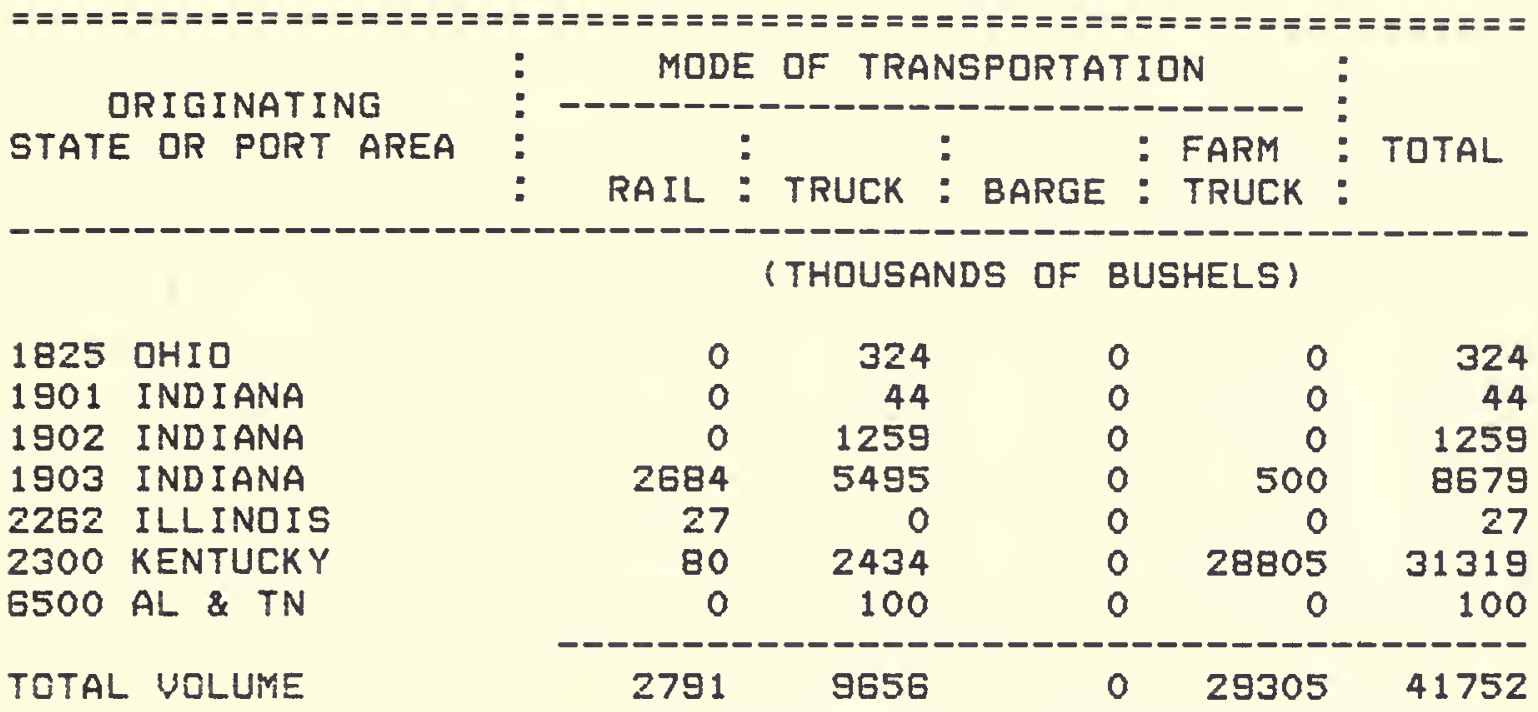

TABLE 44. 1977 SOYBEAN SHIPMENTS TO UARIDUS DESTINATIDNS BY FIRMS IN AREA 2300, KENTUCKY

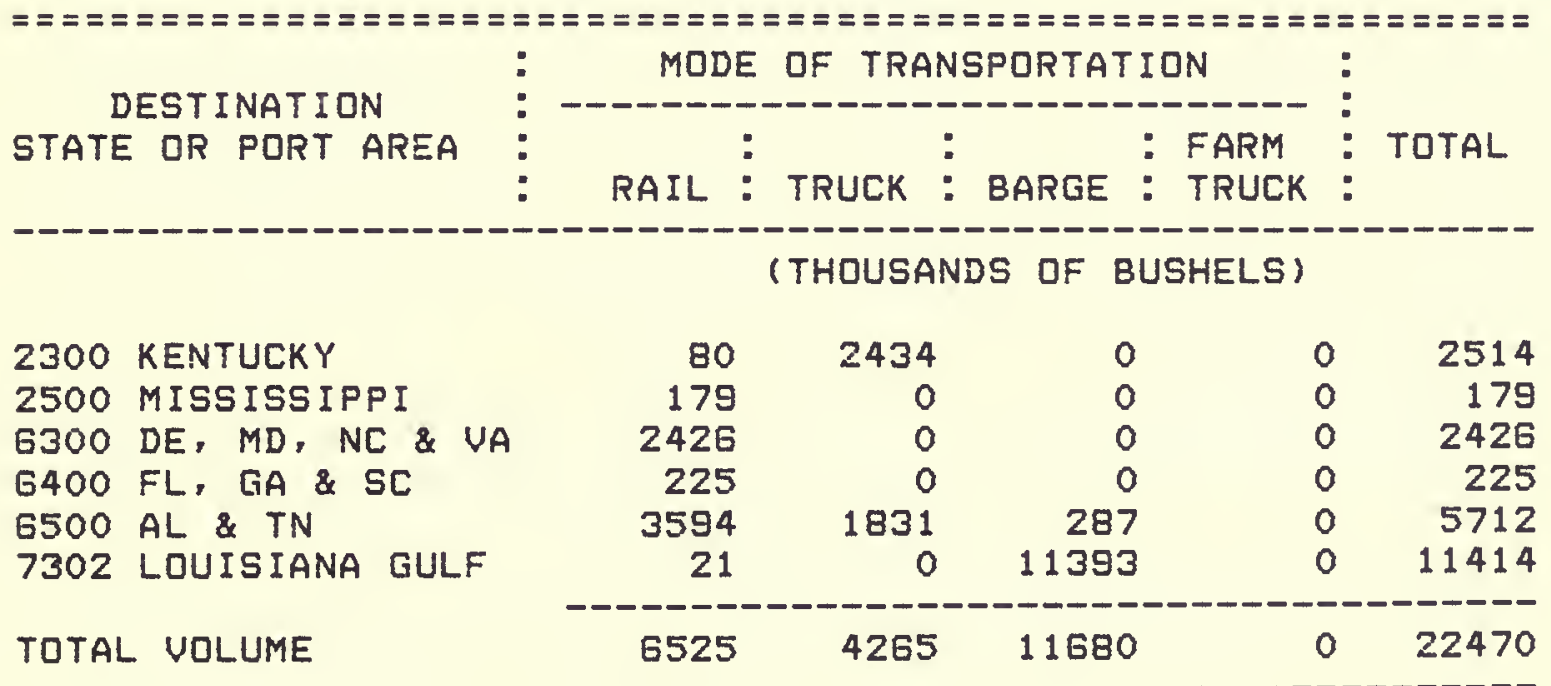


TABLE 45. 1977 SOYBEAN RECEIPTS FROM UARIOUS ORIGINS BY FIRMS IN AREA 3100, LOUISIANA

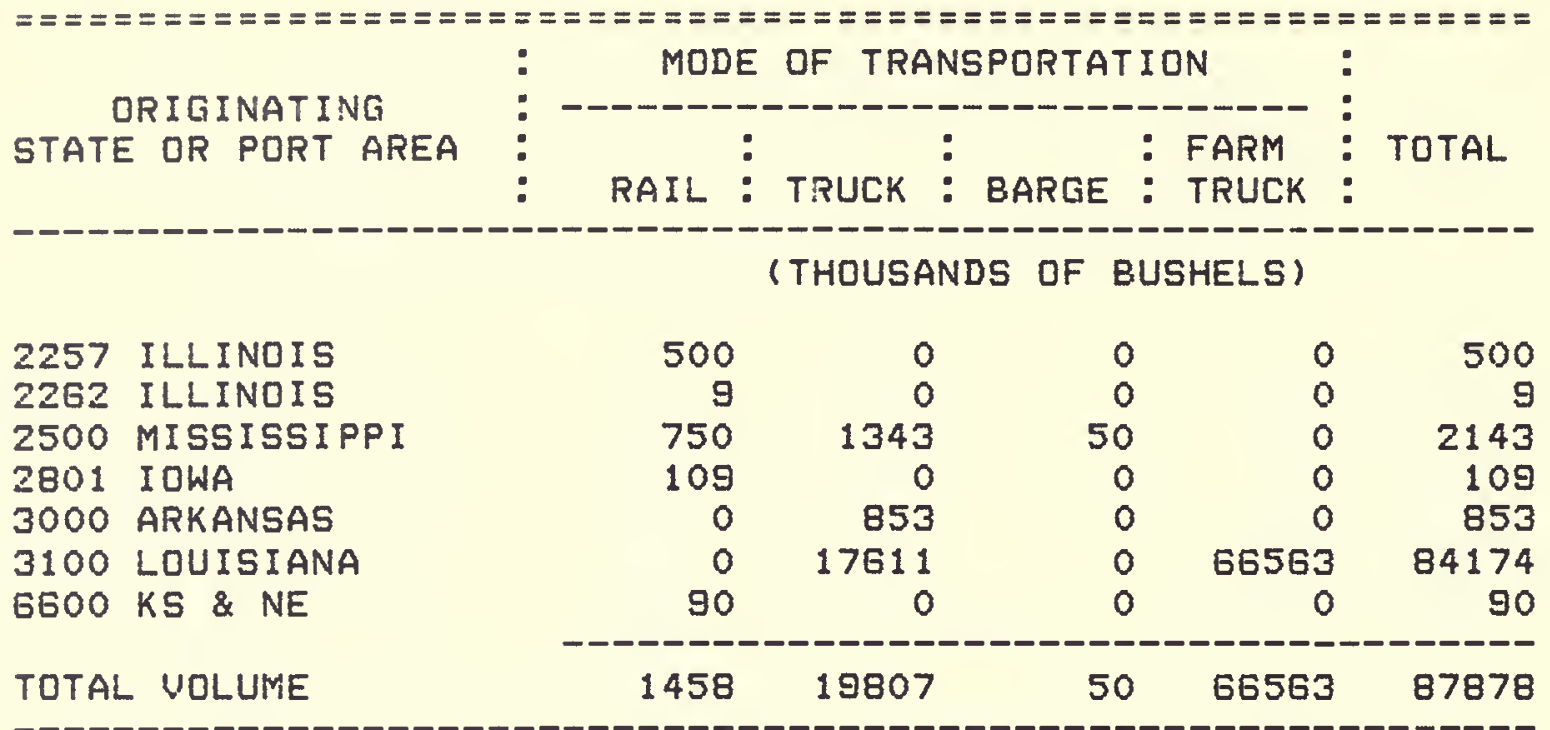

TABLE 46. 1977 SOYBEAN SHIPMENTS TO UARIOUS DESTINATIONS BY FIRMS IN AREA 3100 , LOUISIANA

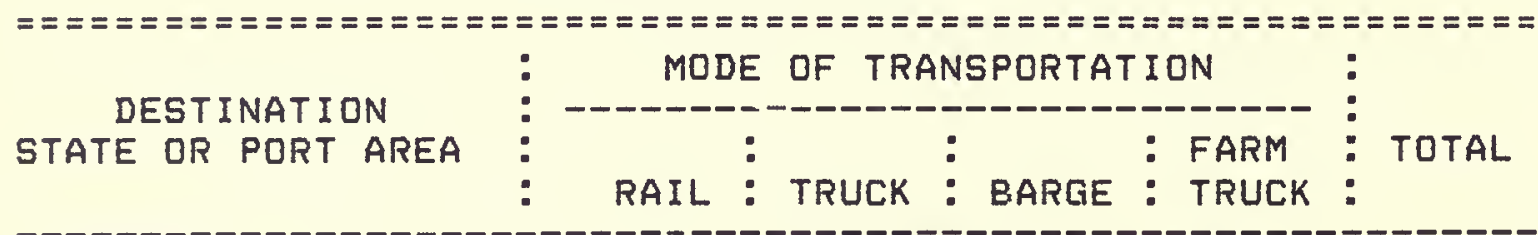

(THOUSANDS OF BUSHELS)

\begin{tabular}{|c|c|c|c|c|c|c|c|}
\hline 2500 & MISSISSIPF & & 0 & 3377 & 0 & 0 & 3377 \\
\hline 3100 & LOUIS IANA & & 0 & 17611 & 0 & 0 & 17611 \\
\hline 7302 & LOUISIANA & GULF & 1613 & 9744 & 45381 & 0 & 56738 \\
\hline 7303 & NO. TEXAS & GULF & 13 & 9421 & 0 & 0 & 9434 \\
\hline DTA & VOLUME & & 1626 & 40153 & 45381 & 0 & 87160 \\
\hline
\end{tabular}


TABLE 47. 1977 SOYBEAN RECEIPTS FROM UARIOUS ORIGINS BY FIRMS IN AREA 2000, MICHIGAN

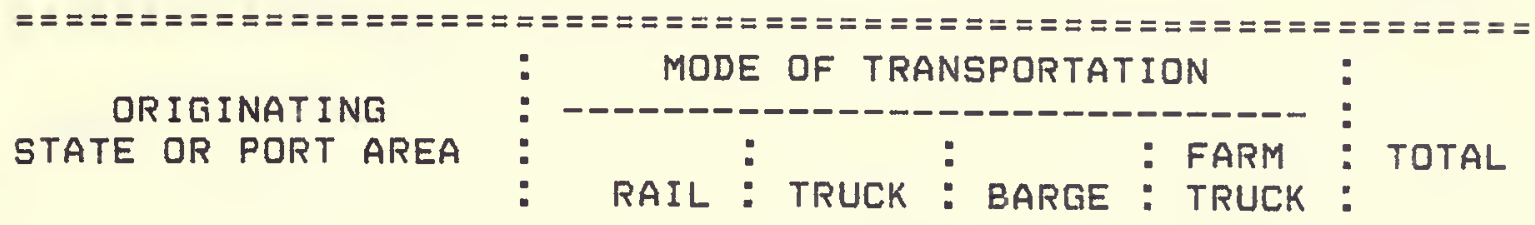

(THOUSANDS OF BUSHELS)

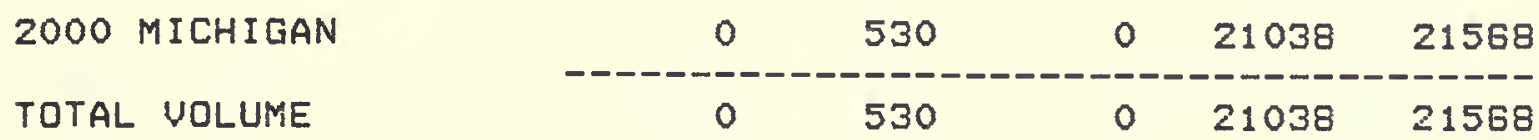

TABLE 48. 1977 SOYBEAN SHIPMENTS TO UARIOUS DESTINATIONS BY FIRMS IN AREA 2000, MICHIGAN

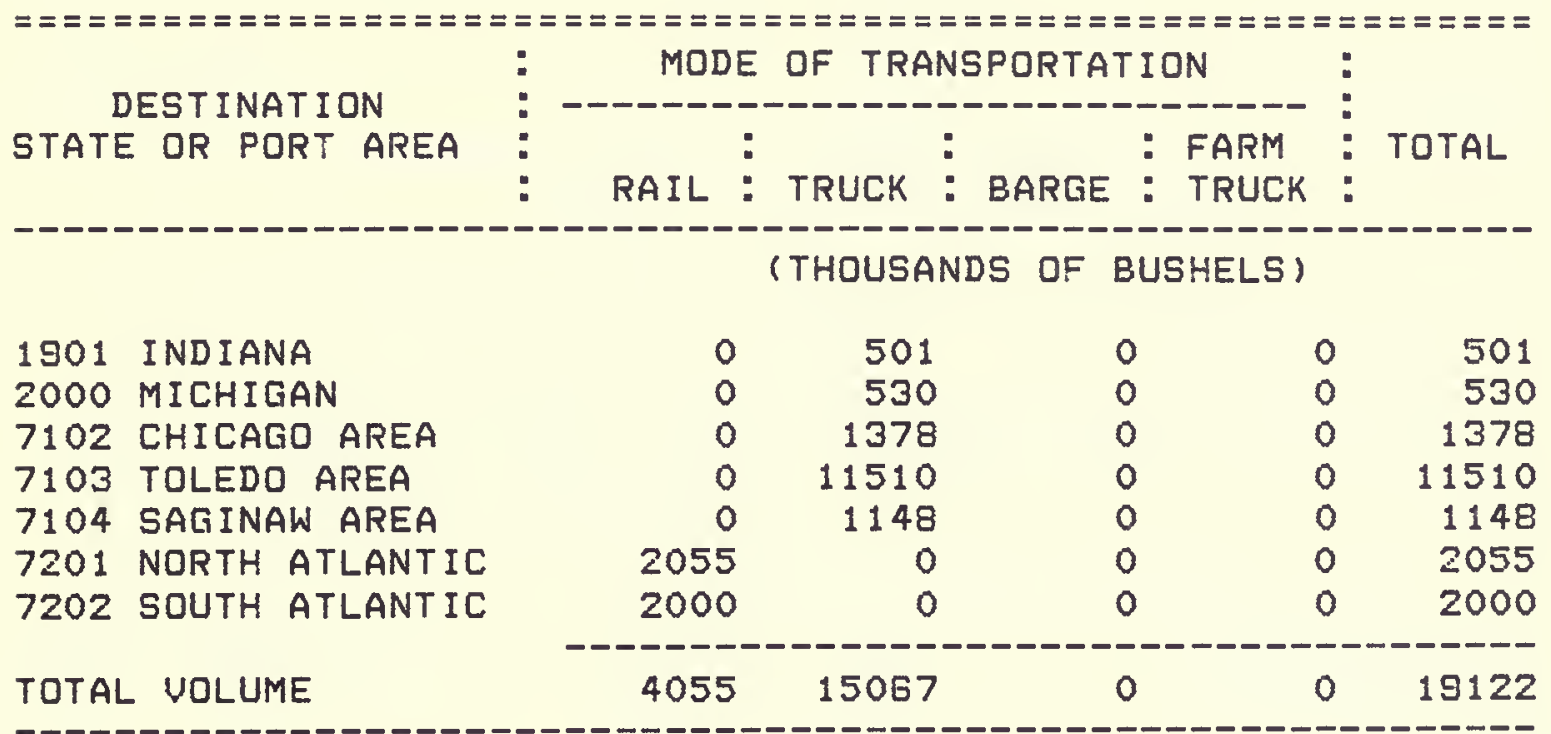

TABLE 49. 1977 SOYBEAN RECEIPTS FROM UARIOUS ORIGINS BY FIRMS IN AREA 2701, MINNESOTA

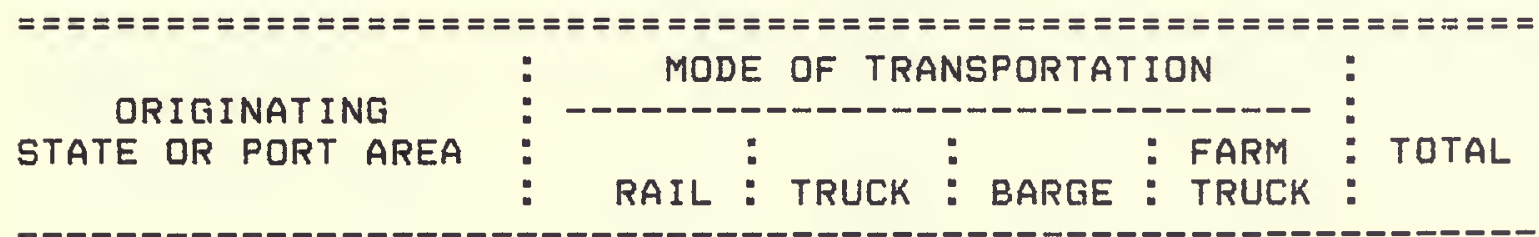

(THOUSANDS OF BUSHELS)

2701 MINNESOTA

TOTAL VOLUME

$\begin{array}{ccccr}0 & 2 & 0 & 344 & 346 \\ 0 & 2 & 0 & 344 & 346\end{array}$


TABLE 5O. 1977 SOYBEAN SHIPMENTS TO UARIOUS DESTINATIONS BY FIRMS IN AREA 2701, MINNESOTA

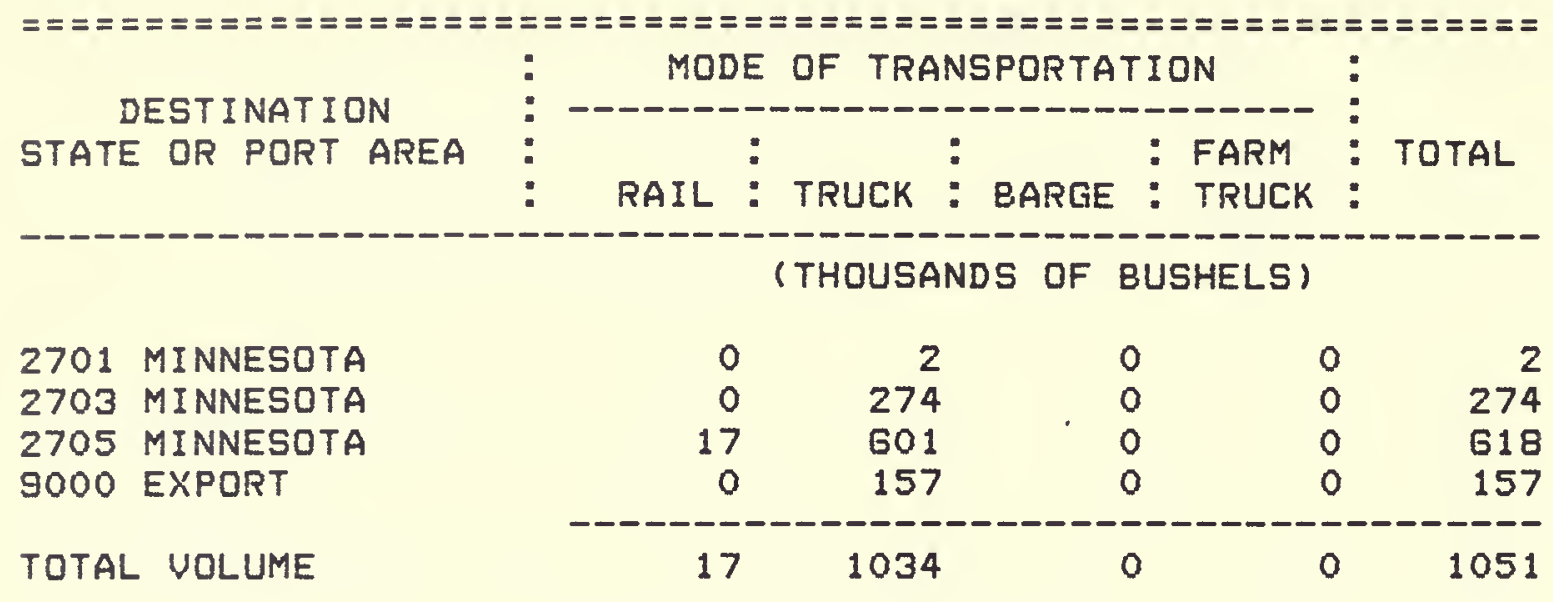

TABLE 51. 1977 SOYBEAN RECEIPTS FROM VARIOUS ORIGINS BY FIRMS IN AREA 2703, MINNESOTA

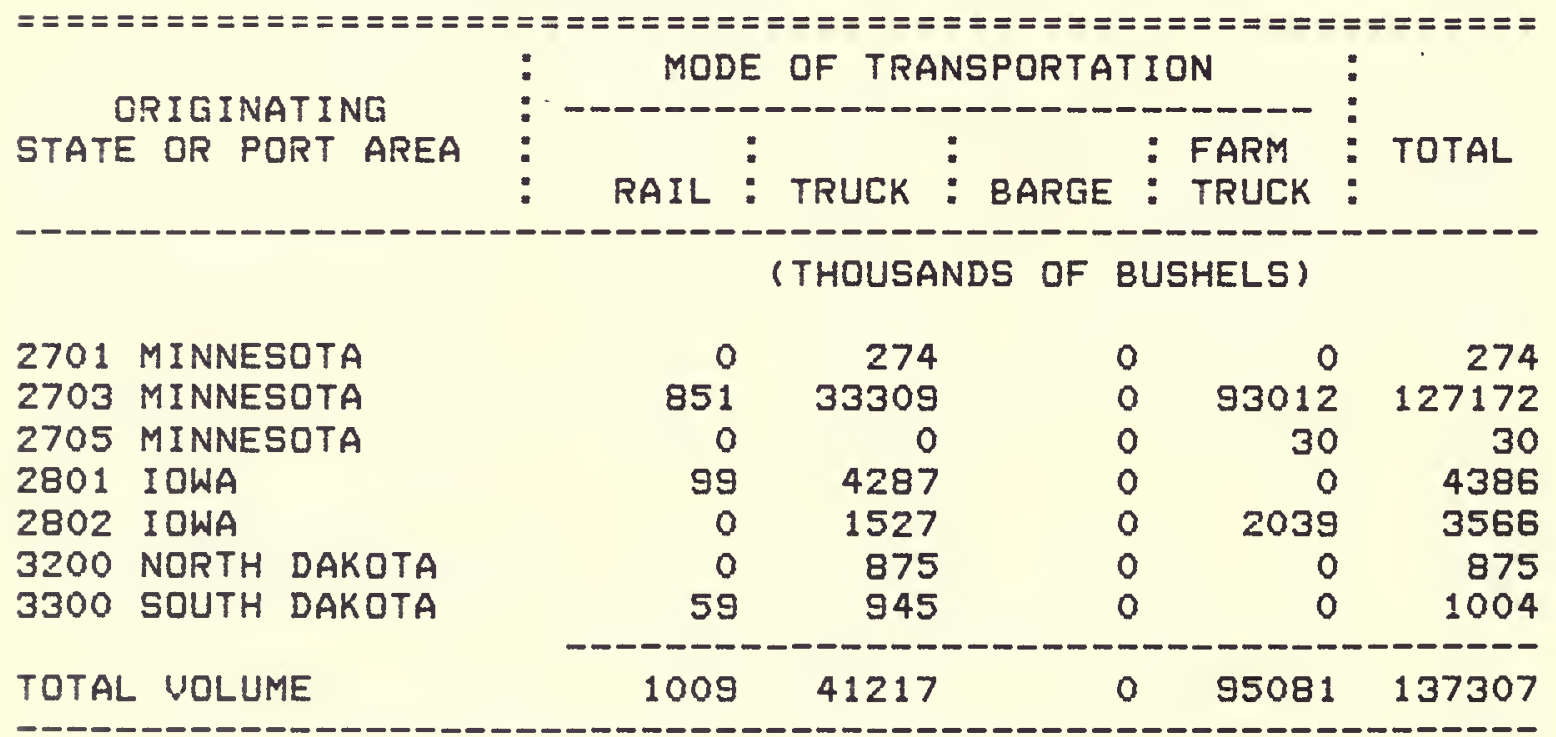


TABLE 52. 1977 SOYBEAN SHIPMENTS TO UARIOUS DESTINATIONS BY FIRMS IN AREA 2703, MINNESOTA

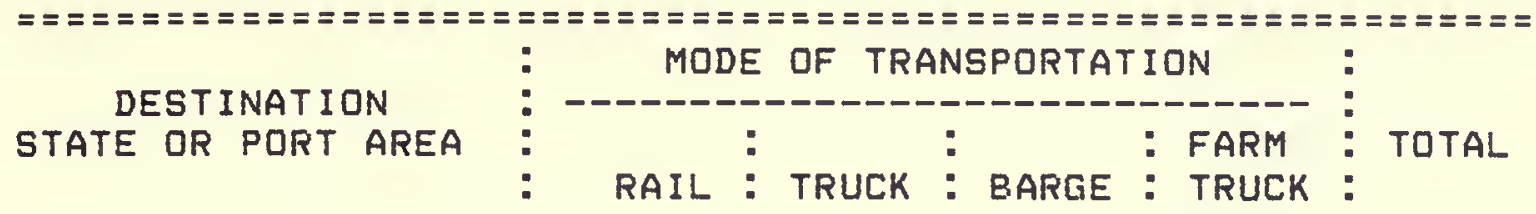

( THOUSANDS OF BUSHELS)

$\begin{array}{llrrrrr}2703 & \text { MINNESOTA } & 851 & 33309 & 0 & 90 & 34250 \\ 2705 & \text { MINNESOTA } & 5782 & 24414 & 0 & 0 & 30196 \\ 2801 & \text { IOWA } & 0 & 4097 & 0 & 0 & 4097 \\ 2802 & \text { IOWA } & 929 & 413 & 0 & 0 & 1342 \\ 2803 & \text { IOWA } & 18 & 331 & 0 & 0 & 349 \\ 7301 \text { EAST GULF } & 3636 & 0 & 0 & 0 & 3636 \\ 7303 \text { NO. TEXAS EULF } & 396 & 0 & 0 & 0 & 396 \\ 7401 \text { COLUMBIA RIUER } & 349 & 0 & 0 & 0 & 349 \\ 7402 \text { PUGET SOUND } & 190 & 0 & 0 & 0 & 190 \\ \text { 9000 EXPORT } & 0 & 36 & 0 & 0 & 36 \\ \text { TOTAL UQLUME } & --12151 & 62600 & 0 & 90 & 74841\end{array}$

TABLE 53. 1977 SOYBEAN RECEIPTS FROM UARIOUS ORIGINS BY FIRMS IN AREA 2705, MINNESOTA

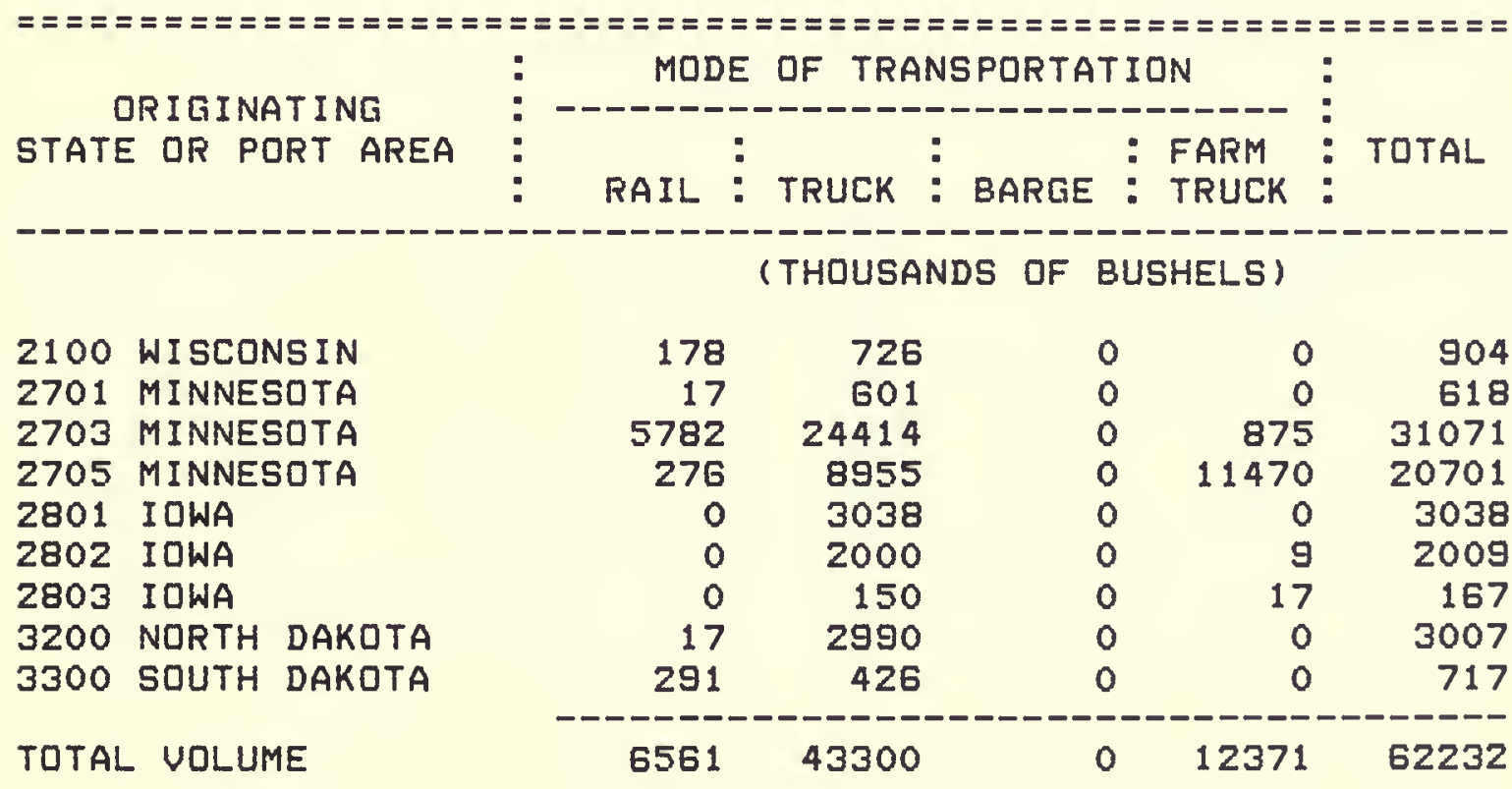


TABLE 54. 1977 SOYBEAN SHIPMENTS TO UARIOUS DESTINATIONS BY FIRMS IN AREA 2705, MINNESOTA

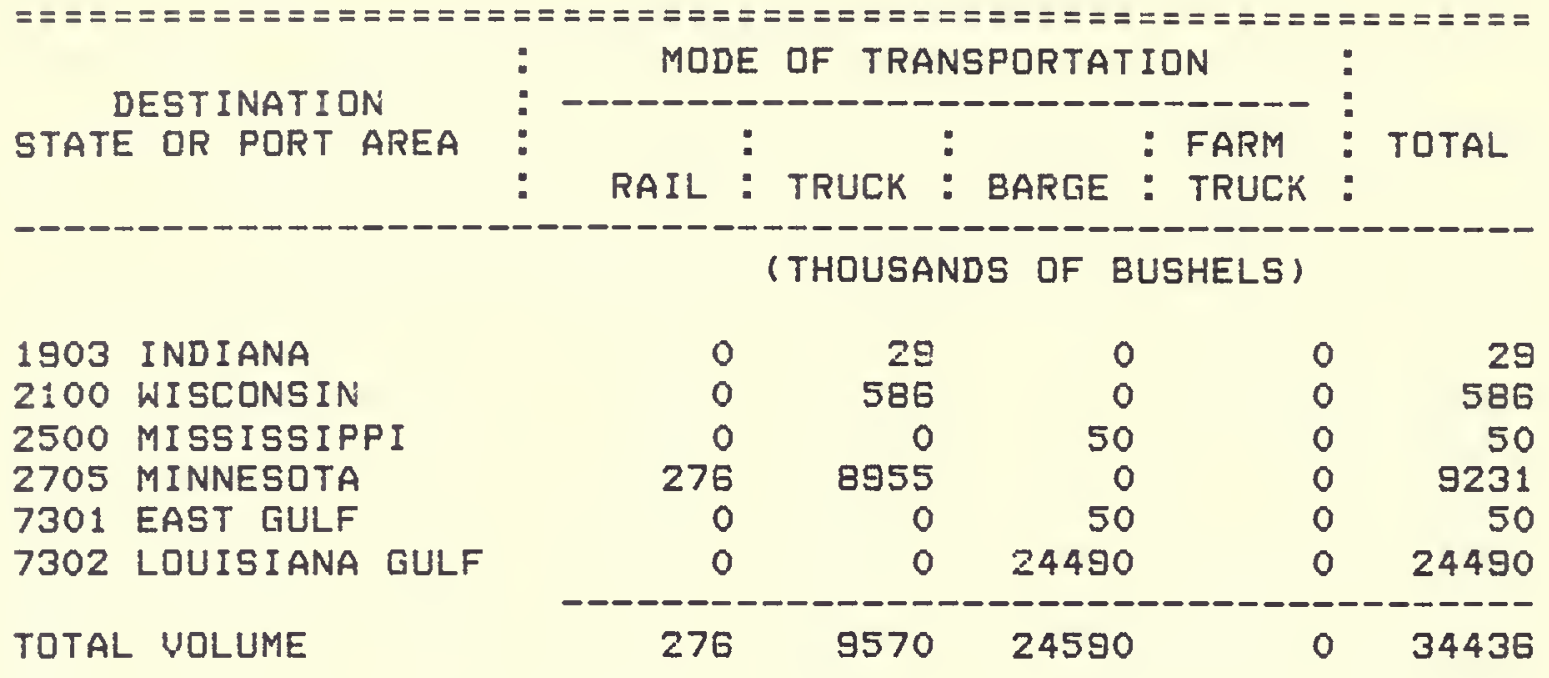

TABLE 55. 1977 SOYBEAN RECEIPTS FROM UARIQUS QRIGINS BY FIRMS IN AREA 2500, MISSISSIPPI

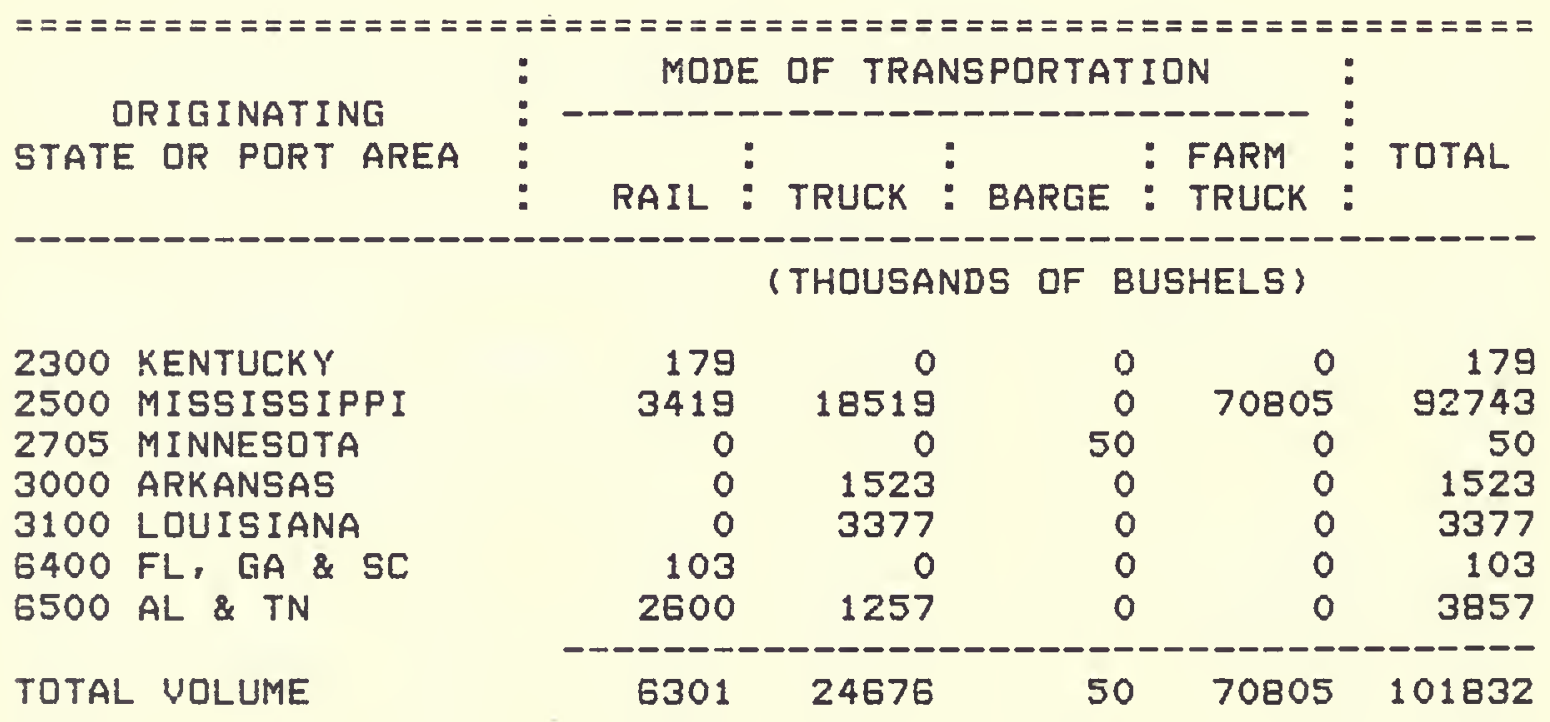


TABLE 5G. 1977 SOYBEAN SHIPMENTS TO UARIOUS DESTINATIONS BY FIRMS IN AREA 2500, MISSISSIPPI

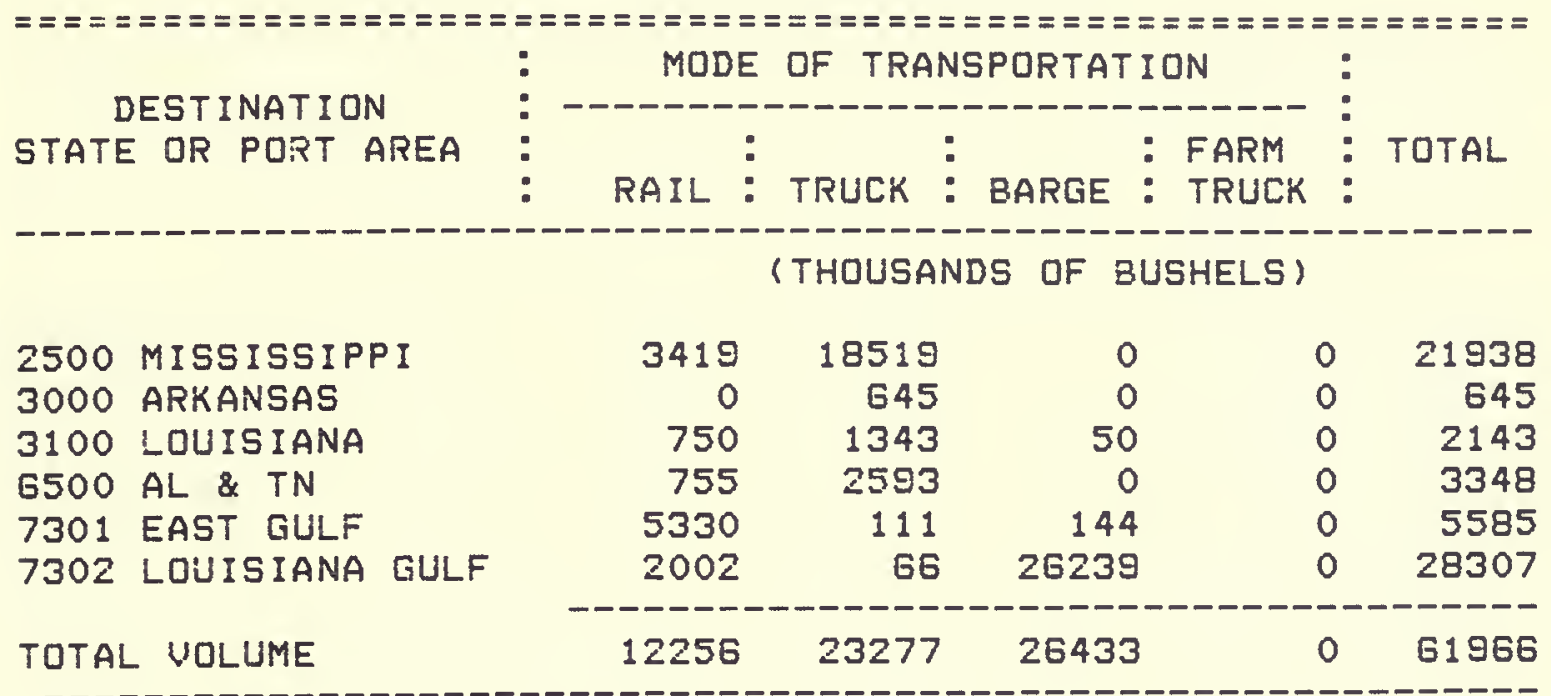

TABLE 57. 1977 SOYBEAN RECEIPTS FROM VARIOUS ORIGINS BY FIRMS IN AREA 2900, MISSOURI

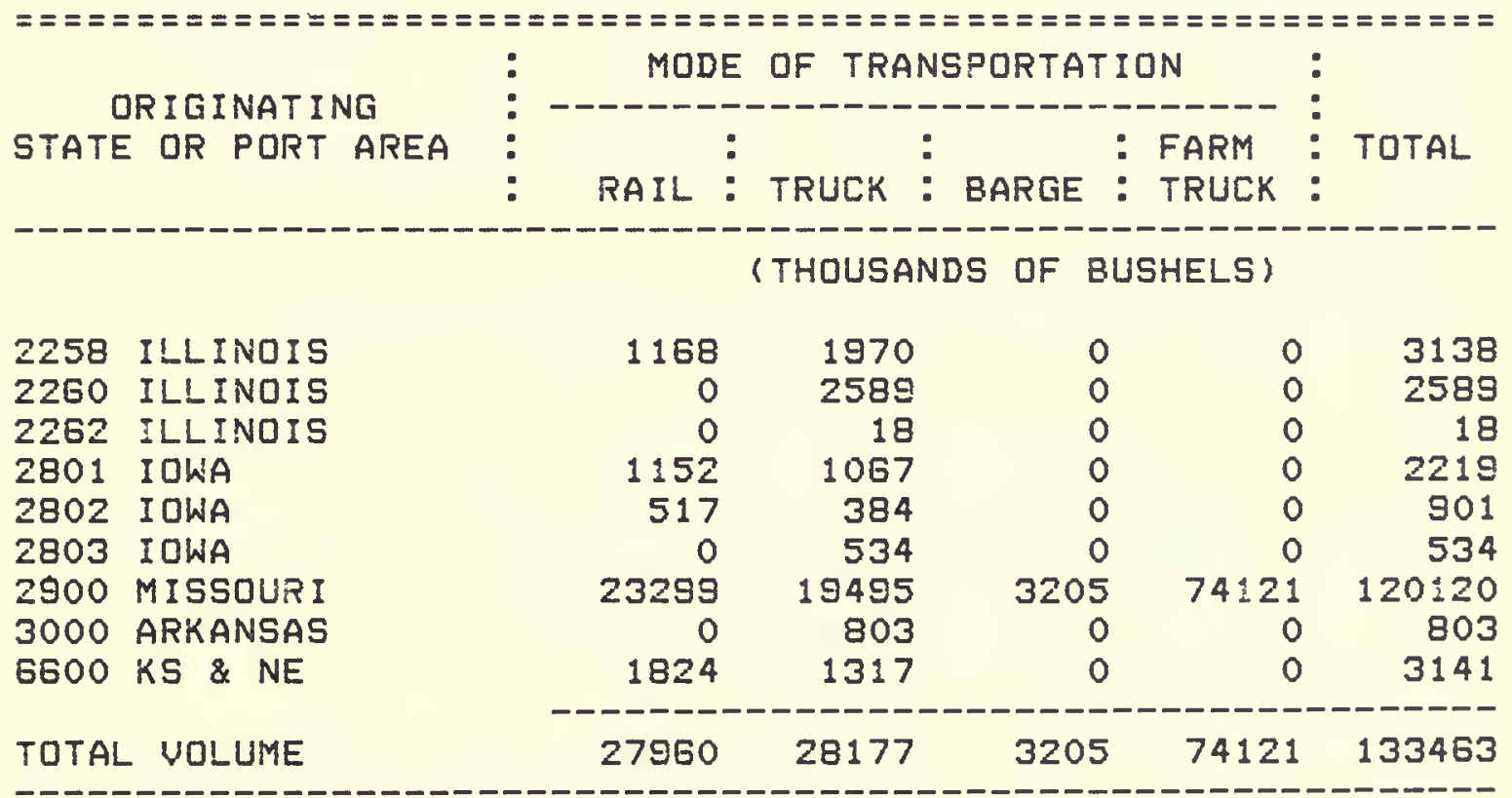


TABLE 5E. 1977 SDYBEAN SHIPMENTS TO UARIOUS DESTINATIONS BY FIRMS IN AREA 2900, MISSOURI

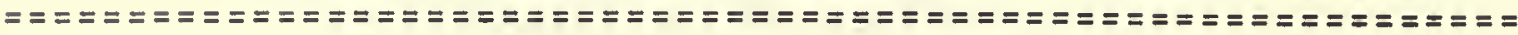

DESTINATION

STATE OR PORT AREA
MODE OF TRANSPORTATION

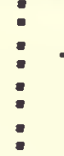

MODE OF TRANSPORTATION

RAIL: TRUCK : BARGE : FARMCK

- - - - - - - - - - -

2261 ILLINOIS

2262 ILLINOIS

2900 MISSOURI

3000 ARKANSAS

G500 AL \& TN

G600 KS \& NE

7301 EAST GULF

7302 LOUISIANA GULF

7303 NO. TEXAS GULF

TOTAL VOLUME

TOTAL

\section{(THOUSANDS OF BUSHELS)}

\begin{tabular}{rrrrr}
3698 & 15859 & 0 & 0 & 19557 \\
43 & 1557 & 0 & 0 & 1600 \\
23299 & 19495 & 3205 & 0 & 45999 \\
2905 & 1919 & 0 & 0 & 4824 \\
277 & 0 & 2000 & 0 & 2277 \\
6627 & 1705 & 0 & 0 & 8332 \\
575 & 0 & 153 & 0 & 728 \\
0 & 0 & 40777 & 0 & 40777 \\
1229 & 0 & 0 & 0 & 1229 \\
\hline 38653 & 40535 & 46135 & 0 & 125323
\end{tabular}

TABLE 59. 1977 SOYBEAN RECEIPTS FROM UARIOUS ORIGINS BY FIRMS IN AREA 4100, NEW MEXICO

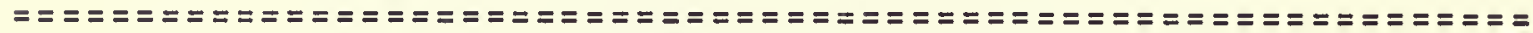

ORIGINATING

STATE DR PORT AREA
MODE OF TRANSPORTATION

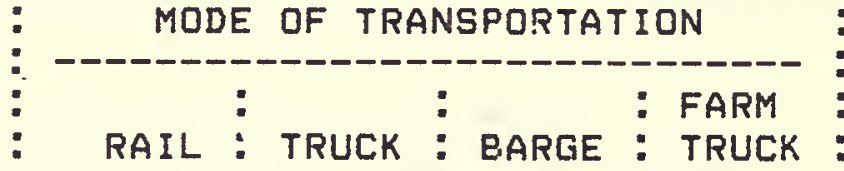

(THOUSANDS OF BUSHELS)

4100 NEW MEXICO

TOTAL VOLUME

$\begin{array}{ccccc}0 & 0 & 0 & 3 & 3 \\ -0 & 0 & 0 & 3 & 3\end{array}$

TABLE 60. 1977 SOYBEAN SHIPMENTS TO VARIOUS DESTINATIONS BY FIRMS IN AREA 4100, NEW MEXICO

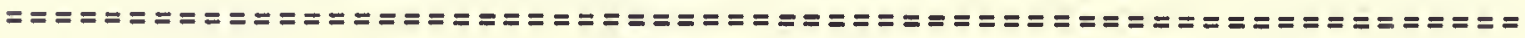

DESTINATION

STATE OR PORT AREA
MODE OF TRANSPORTATION

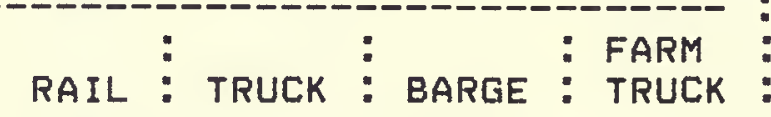

TOTAL

3700 TEXAS

TOTAL VOLUME

(THOUSANDS OF BUSHELS)

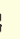


TABLE 61. 1977 SOYBEAN RECEIPTS FROM UARIOUS ORIGINS BY FIRMS IN AREA 3200, NORTH DAKOTA

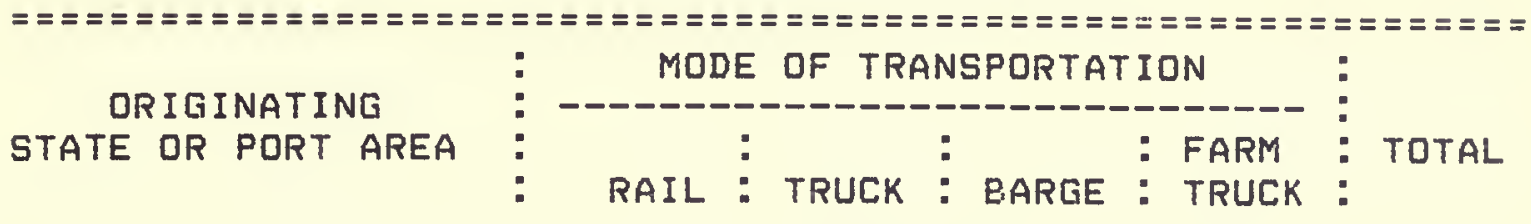

(THOUSANDS OF BUSHELS)

3200 NORTH DAKOTA

TOTAL VOLUME

$\begin{array}{ccccr}0 & 0 & 0 & 3882 & 3882 \\ -0 & 0 & 0 & 3882 & 3882\end{array}$

TABLE 62. 1977 SOYBEAN SHIPMENTS TO VARIOUS DESTINATIONS BY FIRMS IN AREA 3200, NDRTH DAKDTA

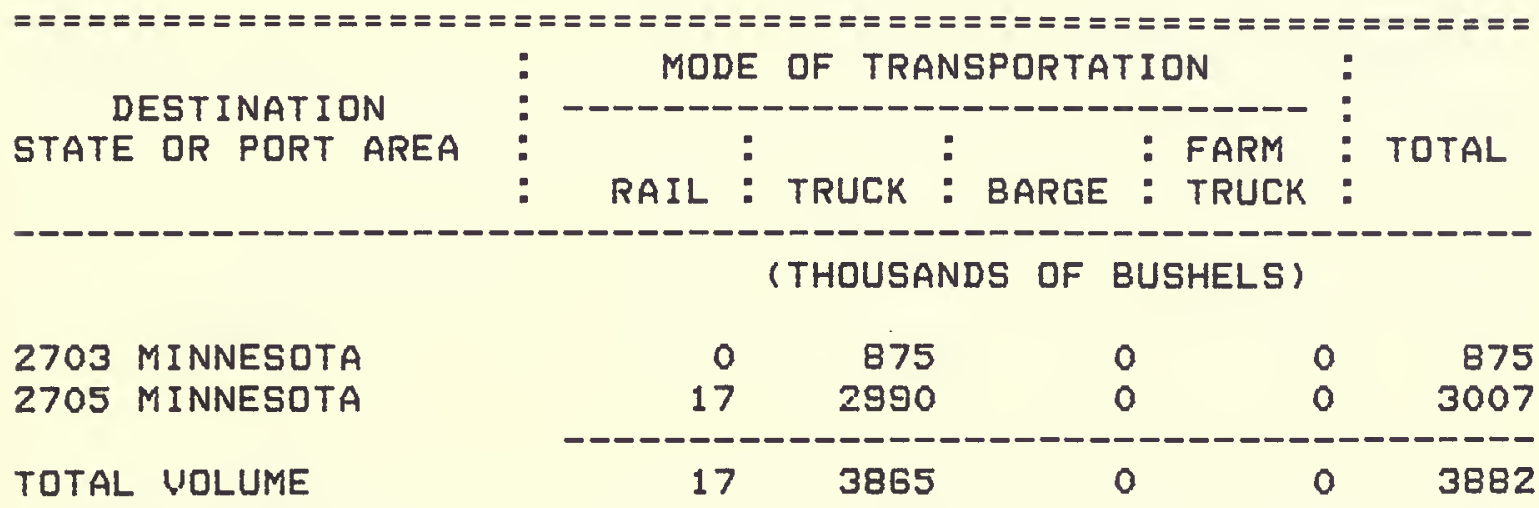

TABLE 63. 1977 SOYBEAN RECEIPTS FROM UARIOUS ORIGINS BY FIRMS IN AREA 1825 , OHIO

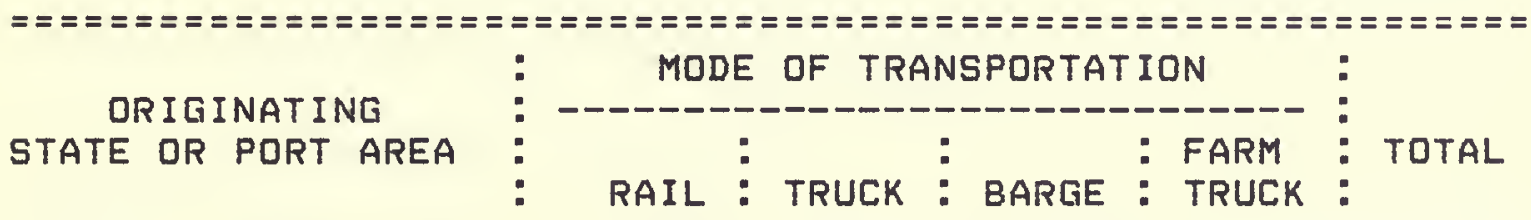

(THOUSANDS OF BUSHELS)

$\begin{array}{llrrrrr}1825 & \text { OHIO } & 127 & 14893 & 0 & 41677 & 56697 \\ 1850 & \text { OHID } & 10 & 1301 & 0 & 1468 & 2779 \\ 1902 \text { INDIANA } & 0 & 3214 & 0 & 2624 & 5838 \\ 1903 \text { INDIANA } & 0 & 722 & 0 & 1289 & 2011 \\ 2300 \text { KENTUCKY } & 0 & 0 & 0 & 518 & 518 \\ \text { TOTAL UDLUME } & --137 & 20130 & 0 & 47576 & 67843\end{array}$


TABLE 64. 1977 SOYBEAN SHIPMENTS TO VARIOUS DESTINATIONS BY FIRMS IN AREA 1825, DHIO

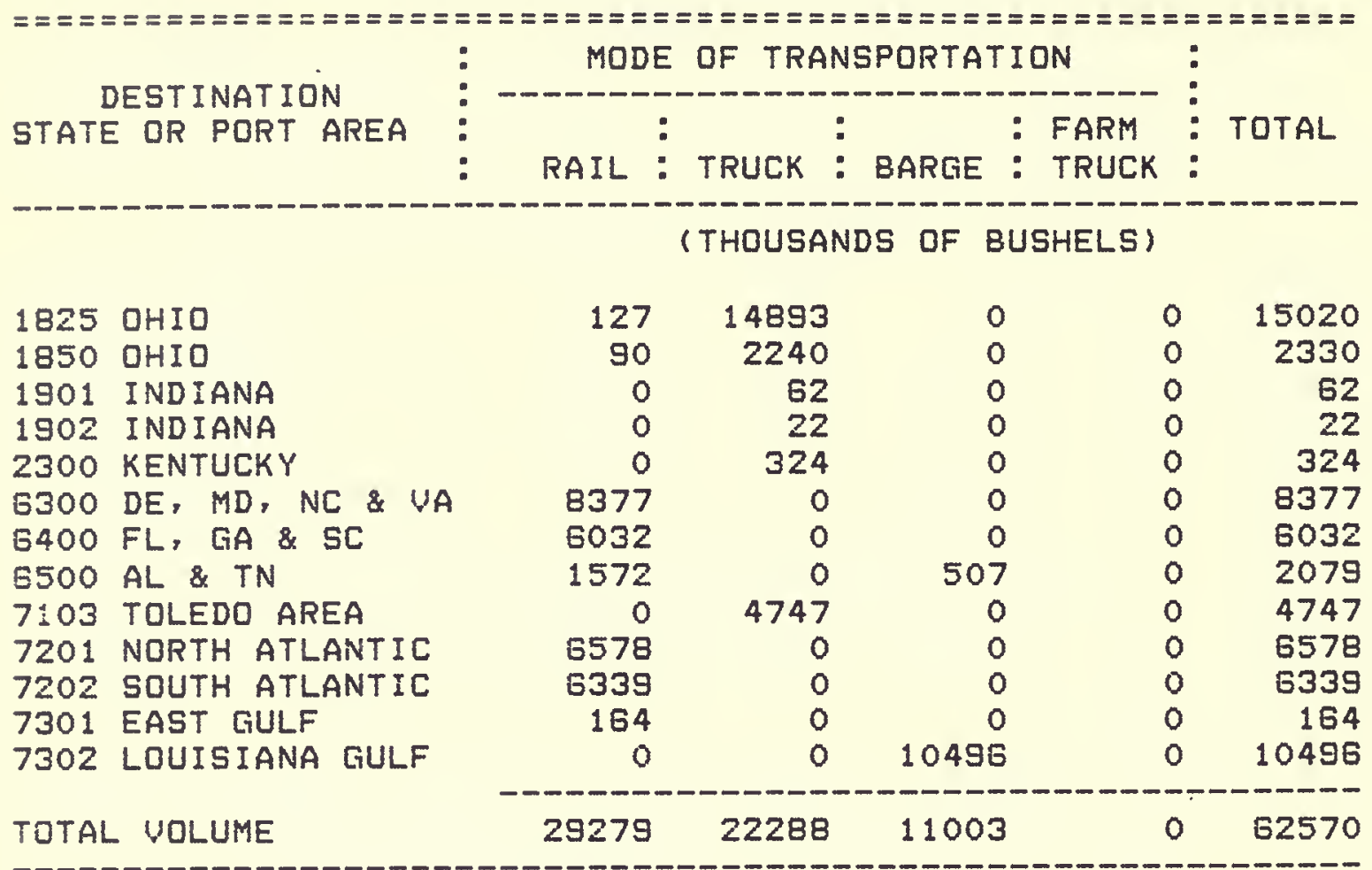

TABLE 65. 1977 SOYBEAN RECEIPTS FROM UARIOUS ORIGINS BY FIRMS IN AREA 1850, DHID

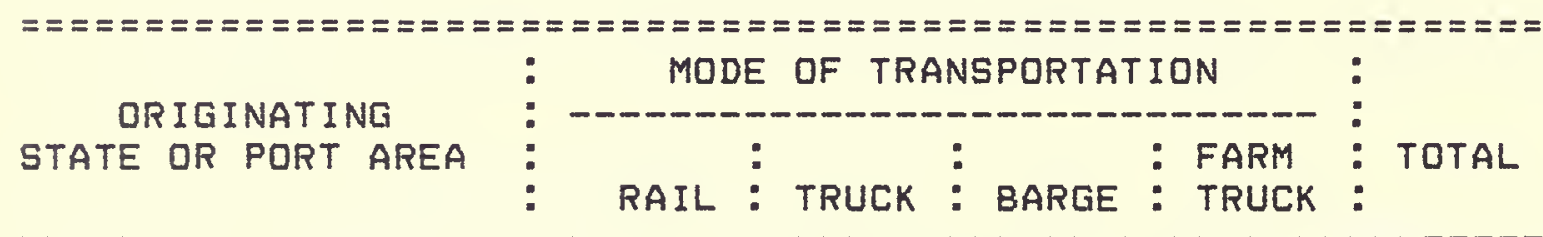

(THOUSANDS OF BUSHELS)

$\begin{array}{lrrrrr}1825 \text { OHIO } & 90 & 2240 & 0 & 1018 & 3348 \\ 1850 \text { OHIO } & 124 & 14968 & 0 & 37922 & 53014 \\ \text { TOTAL VOLUME } & 214 & 17208 & 0 & 38940 & 56362\end{array}$


TABLE 6E. 1977 SOYBEAN SHIPMENTS TO UARIOUS DESTINATIONS BY FIRMS IN AREA 1850 , OHIO

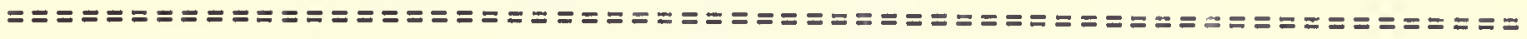

DESTINATION

STATE OR PORT AREA
MODE OF TRANSPORTATION

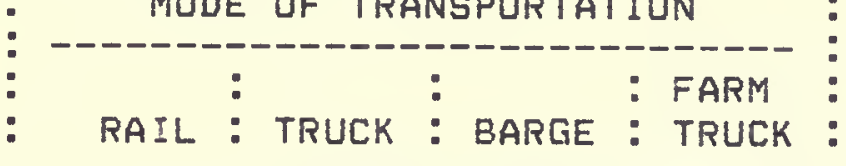

TOTAL.

(THOUSANDS OF BUSHELS)

$\begin{array}{llrrrrr}1825 & \text { OHIO } & 10 & 1301 & 0 & 0 & 1311 \\ 1850 \text { OHIO } & 124 & 14968 & 0 & 0 & 15092 \\ 1901 \text { INDIANA } & 0 & 4364 & 0 & 0 & 4364 \\ 1902 & \text { INDIANA } & 0 & 189 & 0 & 0 & 189 \\ 7103 & \text { TOLEDO AREA } & 3713 & 21359 & 0 & 0 & 25072 \\ 7201 & \text { NORTH ATLANTIC } & 207 & 0 & 0 & 0 & 207 \\ 7202 \text { SOUTH ATLANTIC } & 12953 & 0 & 0 & 0 & 12953 \\ \text { TOTAL VOLUME } & ---17007 & 42181 & 0 & 0 & 59188\end{array}$

TABLE 67. 1977 SOYBEAN RECEIPTS FROM UARIOUS DRIGINS BY FIRMS IN AREA 3GOO, OKLAHOMA

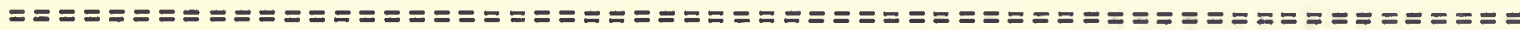

OR IGINAT ING STATE OR PORT AREA
MODE OF TRANSPORTATION

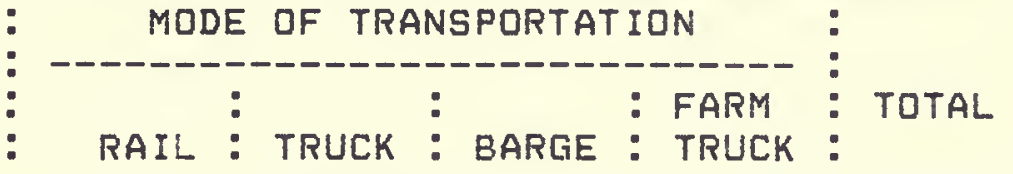

(THOUSANDS OF BUSHELS)

\begin{tabular}{|c|c|c|c|c|}
\hline $\begin{array}{l}3000 \text { ARKANSAS } \\
3600 \text { OKLAHOMA }\end{array}$ & $\begin{array}{l}0 \\
0\end{array}$ & $\begin{array}{r}0 \\
214\end{array}$ & $\begin{array}{l}0 \\
0\end{array}$ & $\begin{array}{r}113 \\
\text { GOOG }\end{array}$ \\
\hline TOTAL VOLUME & 0 & 214 & 0 & G119 \\
\hline
\end{tabular}

TABLE 68. 1977 SOYBEAN SHIPMENTS TO UARIOUS DESTINATIONS BY FIRMS IN AREA 3600 , OKLAHOMA

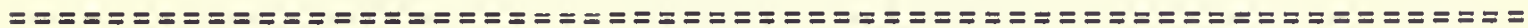

DESTINATION

STATE OR PORT AREA

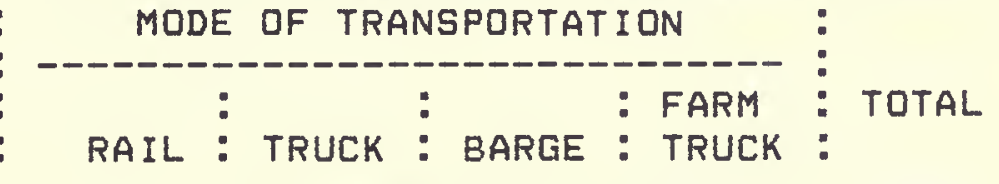

(THOUSANDS OF BUSHELS)

\begin{tabular}{|c|c|c|c|c|c|c|c|}
\hline 3600 & OKLAHOMA & & 0 & 214 & 0 & 0 & 214 \\
\hline 3745 & TEXAS & & 1852 & 984 & 0 & 0 & 2836 \\
\hline 6600 & KS \& NE & & 111 & 325 & 0 & 0 & 436 \\
\hline 7301 & EAST GULF & & 0 & 0 & 350 & 0 & 350 \\
\hline 7302 & LOUISIANA & GULF & 0 & 0 & 1900 & 0 & 1900 \\
\hline OTAL & - VOLUME & & 1963 & 1523 & 2250 & 0 & 5736 \\
\hline
\end{tabular}


TABLE 69. 1977 SOYBEAN RECEIPTS FROM UARIDUS ORIGINS EY FIRMS IN AREA 3300, SDUTH DAKDTA

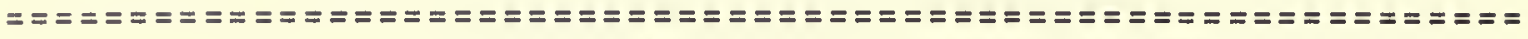

DR IGINATING

STATE OR PORT AREA
MODE OF TRANSPORTATION

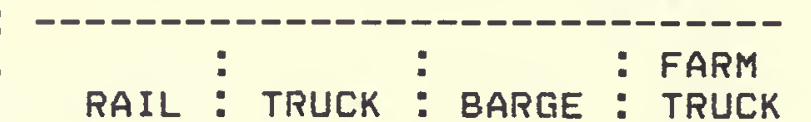

(THOUSANDS DF BUSHELS)

3300 SOUTH DAKOTA

TOTAL VOLUME

$\begin{array}{ccccr}0 & 0 & 0 & 7688 & 7688 \\ 0 & 0 & 0 & 7688 & 7688\end{array}$

TABLE 70. 1977 SOYBEAN SHIPMENTS TO UARIOUS DESTINATIONS BY FIRMS IN AREA 3300, SDUTH DAKDTA

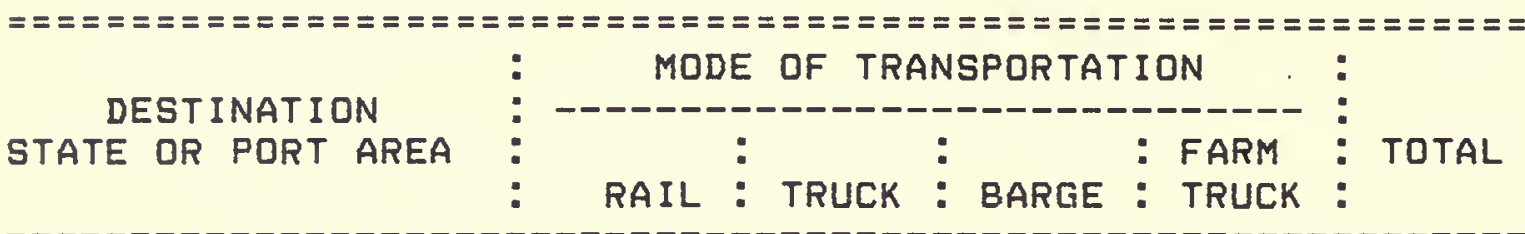

(THOUSANDS OF BUSHELS)

2703 MINNESOTA

2705 MINNESOTA

2801 IDWA

7303 NO. TEXAS GULF

7401 CDLUMBIA RIUER

TOTAL UOLUME

\begin{tabular}{rrrrr}
59 & 945 & 0 & 0 & 1004 \\
291 & 426 & 0 & 0 & 717 \\
1573 & 4626 & 0 & 0 & 6199 \\
51 & 0 & 0 & 0 & 51 \\
0 & 34 & 0 & 0 & 34 \\
\hline 1974 & 6031 & 0 & 0 & 8005
\end{tabular}

TABLE 71. 1977 SOYBEAN RECEIPTS FROM UARIOUS ORIGINS BY FIRMS IN AREA 3700 , TEXAS

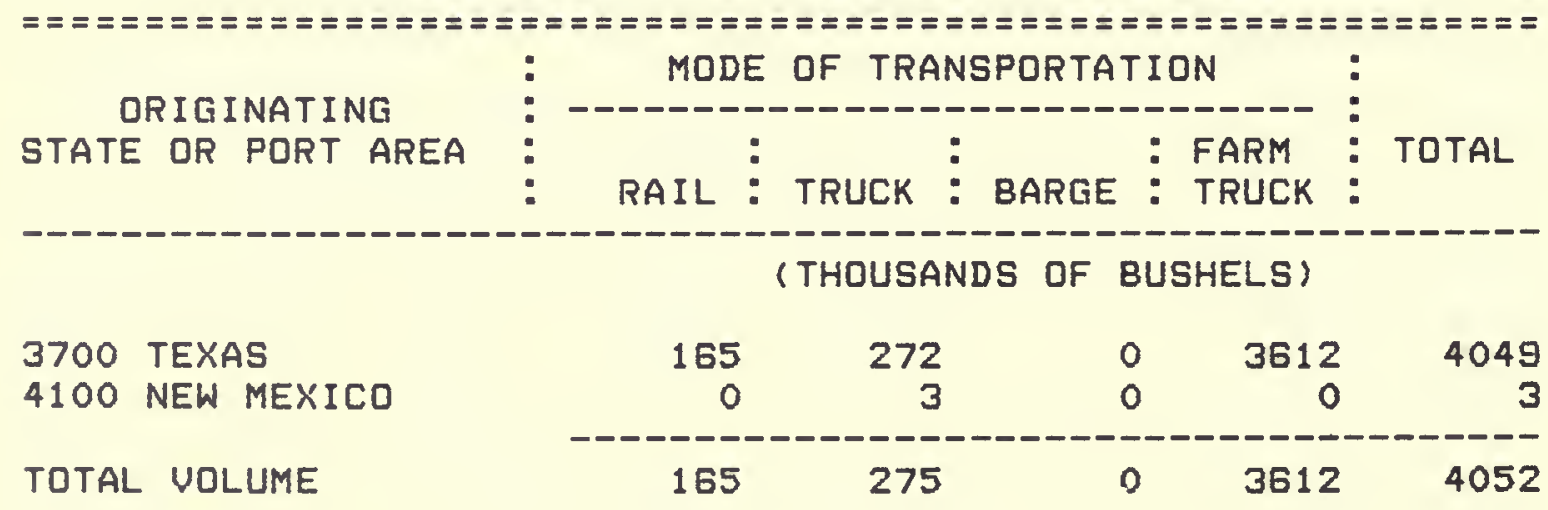


TABLE 72. 1977 SOYBEAN SHIPMENTS TO VARIOUS DESTINATIONS BY FIRMS IN AREA 3700 , TEXAS

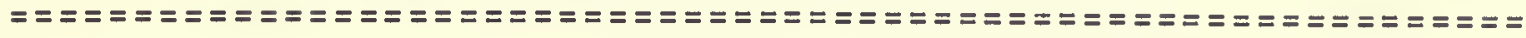

DESTINATION

STATE OR PORT AREA
MODE OF TRANSPORTATION

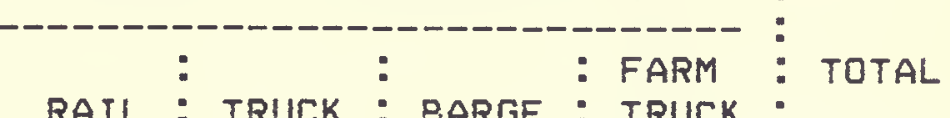

(THOUSANDS OF BUSHELS)

$\begin{array}{llrrrrr}3700 & \text { TEXAS } & 165 & 272 & 0 & 0 & 437 \\ 3745 \text { TEXAS } & 12 & 62 & 0 & 0 & 74 \\ \text { G600 KS \& NE } & 0 & 33 & 0 & 0 & 33 \\ 7302 \text { LOUISIANA GULF } & 360 & 0 & 0 & 0 & 360 \\ 7303 \text { NO. TEXAS GULF } & 1923 & 1304 & 0 & 0 & 3227 \\ \text { TOTAL UOLUME } & --1960 & 1671 & 0 & 0 & 4131\end{array}$

TABLE 73. 1977 SOYBEAN RECEIPTS FROM VARIOUS ORIGINS BY FIRMS IN AREA 3745, TEXAS

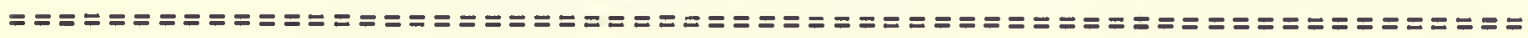

ORIGINAT ING

STATE OR PORT AREA

MODE OF TRANSPORTATION

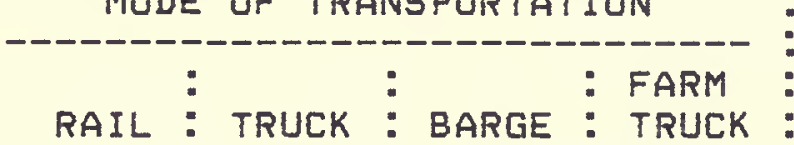

(THOUSANDS OF BUSHELS)

$\begin{array}{llccrrr}3000 & \text { ARKANSAS } & 46 & 141 & 0 & 0 & 187 \\ 3600 & \text { OKLAHOMA } & 1852 & 584 & 0 & 0 & 2836 \\ 3700 & \text { TEXAS } & 12 & 62 & 0 & 0 & 74 \\ 3745 \text { TEXAS } & 18 & 52 & 0 & 1051 & 1121 \\ \text { TOTAL VOLUME } & -1928 & 1239 & 0 & 1051 & 4218\end{array}$

TABLE 74. 1977 SOYBEAN SHIPMENTS TO UARIOUS DESTINATIONS BY FIRMS IN AREA 3745, TEXAS

= = = = = = = = = = = = = = = = = = = = = = = = = = = = = = = = = = = = = = = = = = = = = = =

DESTINATION

STATE OR PORT AREA
MODE OF TRANSPORTATION

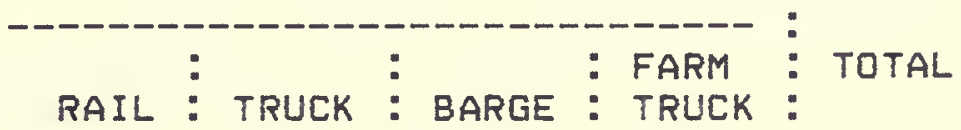

(THOUSANDS OF BUSHELS)

3000 ARKANSAS

3745 TEXAS

TOTAL VOLUME

\begin{tabular}{ccccc}
0 & 75 & 0 & 0 & 75 \\
18 & 52 & 0 & 0 & 70 \\
\hline 18 & 127 & 0 & 0 & 145
\end{tabular}


TABLE 75. 1977 SOYBEAN RECEIPTS FROM VARIOUS ORIGINS BY FIRMS IN AREA 3789 , TEXAS

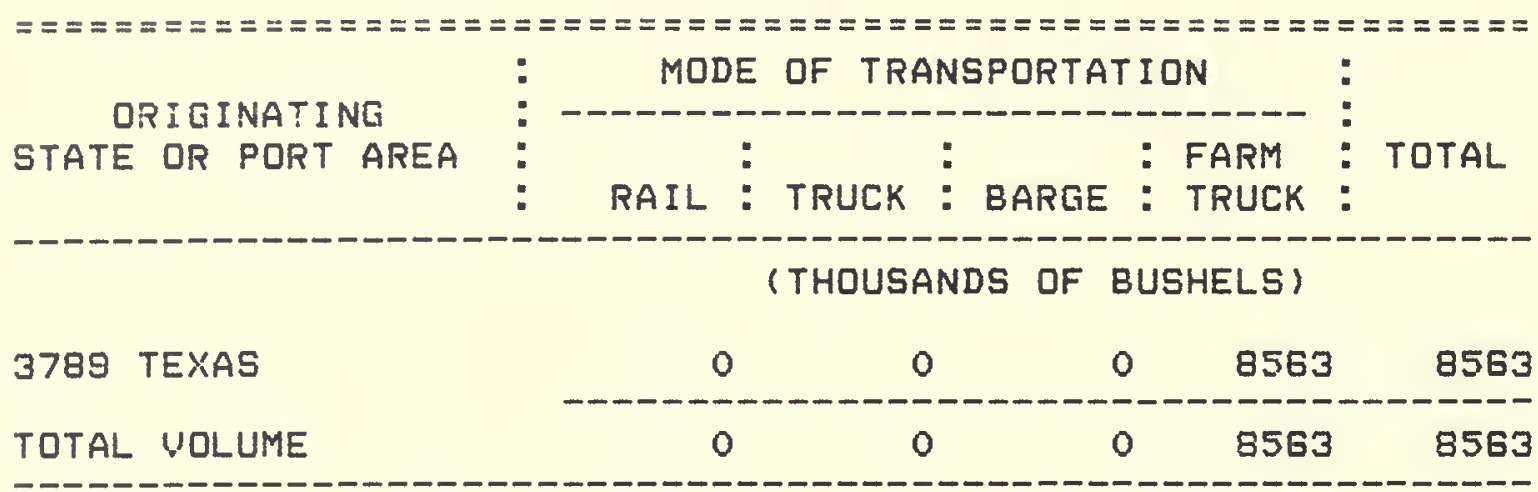

TABLE 76. 1977 SOYBEAN SHIPMENTS TO UARIQUS DESTINATIONS BY FIRMS IN AREA 3789, TEXAS

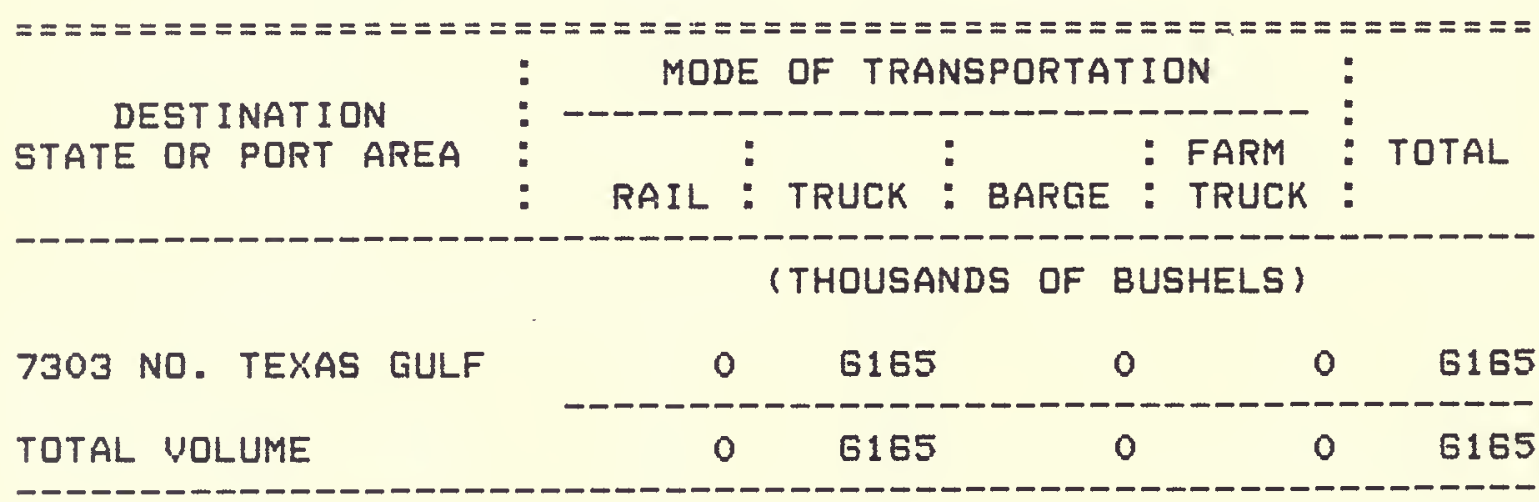

TABLE 77. 1977 SOYBEAN RECEIPTS FROM UARIQUS ORIGINS BY FIRMS IN AREA 2100, WISCONSIN

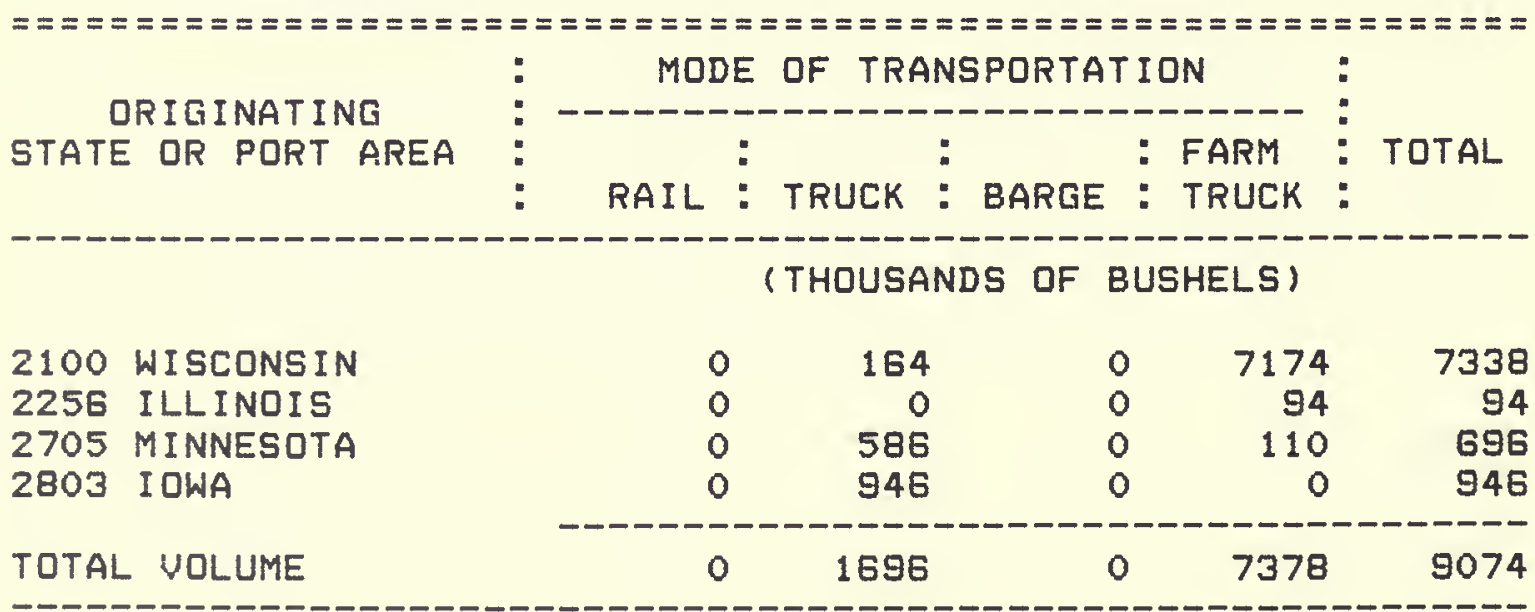


TABLE 78. 1977 SOYBEAN SHIPMENTS TO VARIOUS DESTINATIONS BY FIRMS IN AREA 2100, WISCONSIN

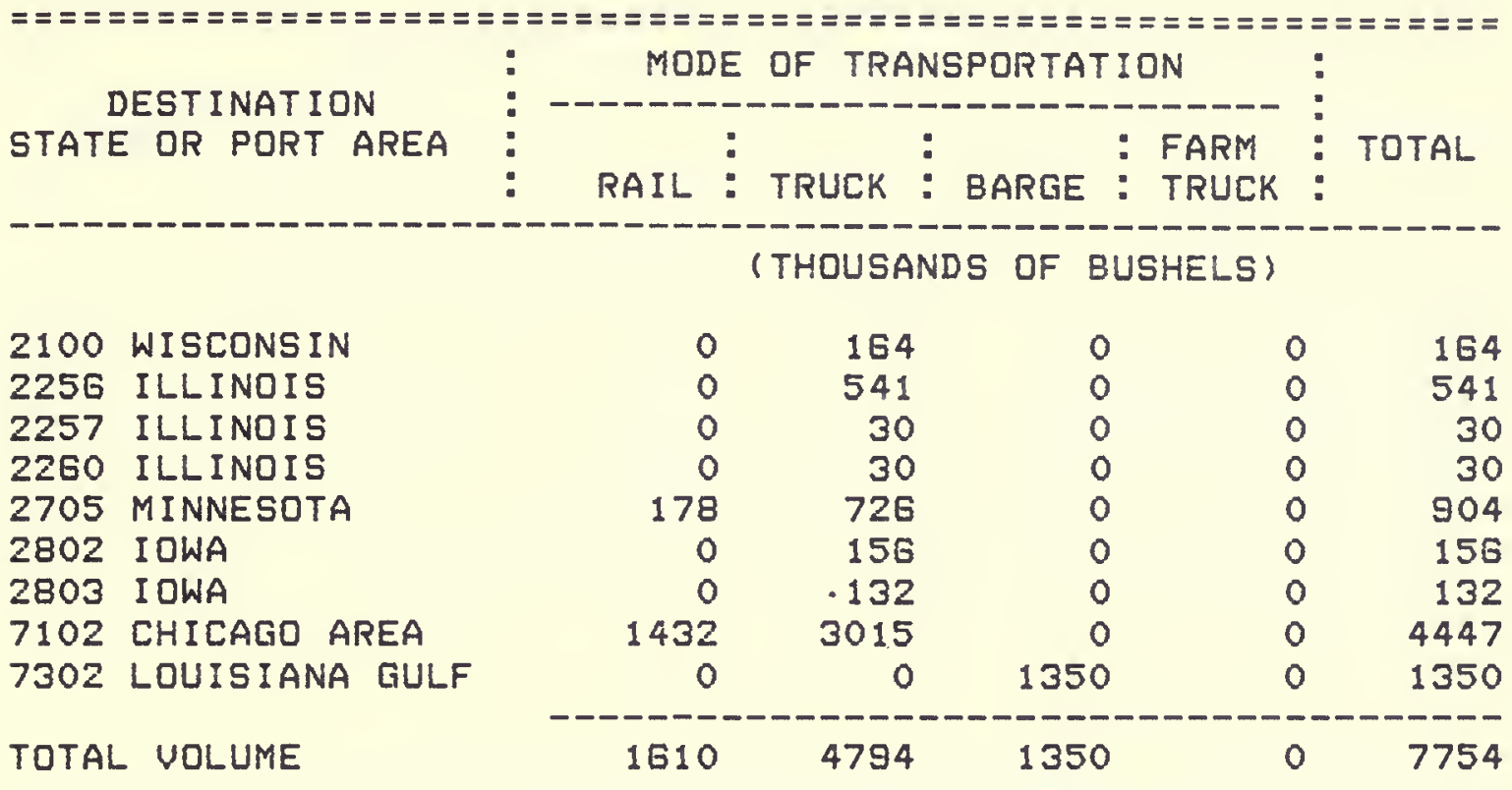

TABLE 79. 1977 SOYBEAN RECEIPTS FROM UARIOUS ORIGINS BY FIRMS IN AREA 6200 , NJ, NY \& PA

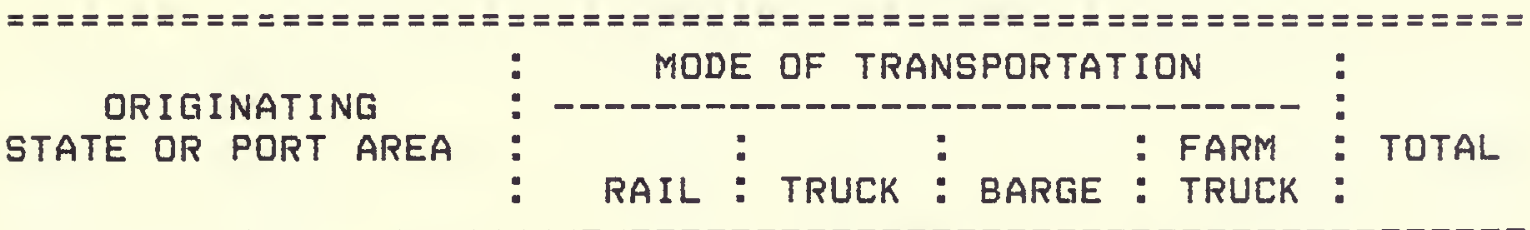
(THOUSANDS OF BUSHELS)

$6200 \mathrm{NJ}, \mathrm{NY} \& \mathrm{PA}$

TOTAL NOLUME

\begin{tabular}{ccccr}
0 & 0 & 0 & 4221 & 4221 \\
\hline 0 & 0 & 0 & 4221 & 4221
\end{tabular}


TABLE 80. 1977 SOYBEAN SHIPMENTS TO UARIOUS DESTINATIONS BY FIRMS IN AREA 6200, NJ, NY \& PA

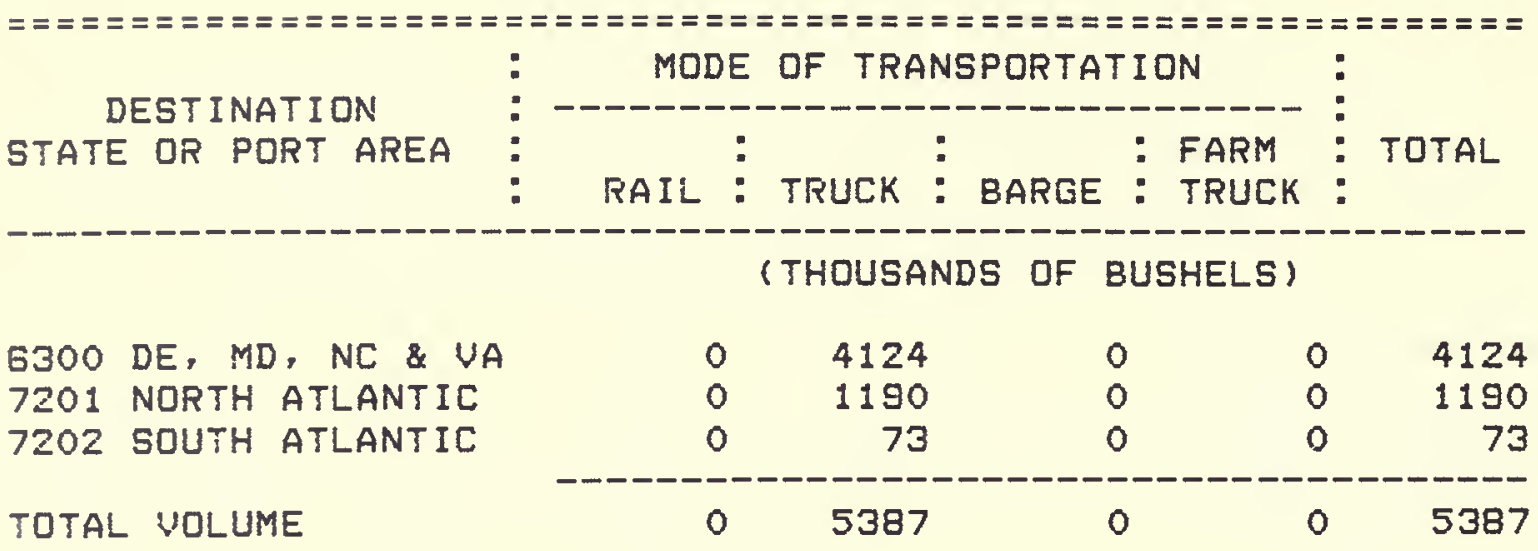

TABLE 81. 1977 SOYBEAN RECEIPTS FROM UARIOUS ORIGINS BY FIRMS IN AREA 6300, DE, MD, NC \& UA

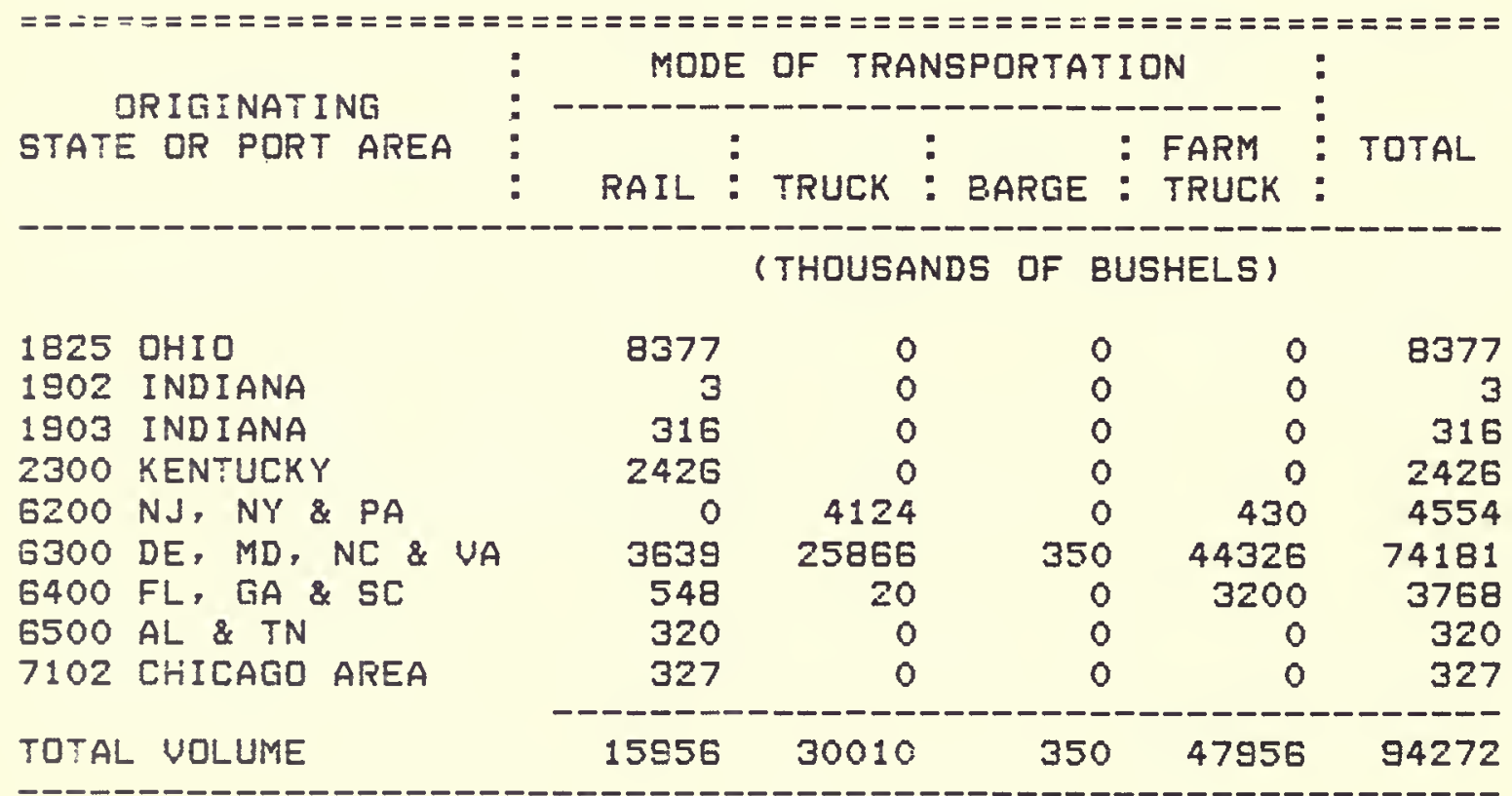


TABLE 82. 1977 SOYBEAN SHIPMENTS TO UARIOUS DESTINATIONS BY FIRMS IN AREA G300, DE, MD, NC \& UA

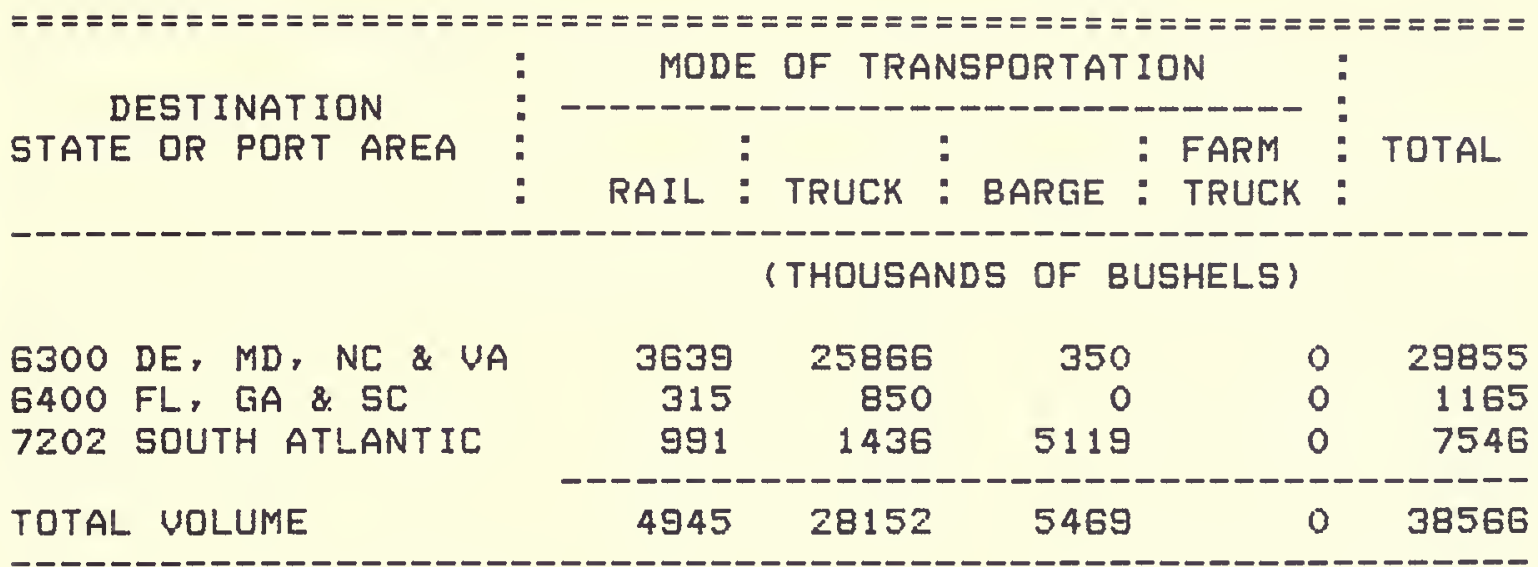

TABLE 83. 1977 SOYBEAN RECEIPTS FROM UARIOUS ORIGINS BY FIRMS IN AREA 6400, FL, GA \& SC

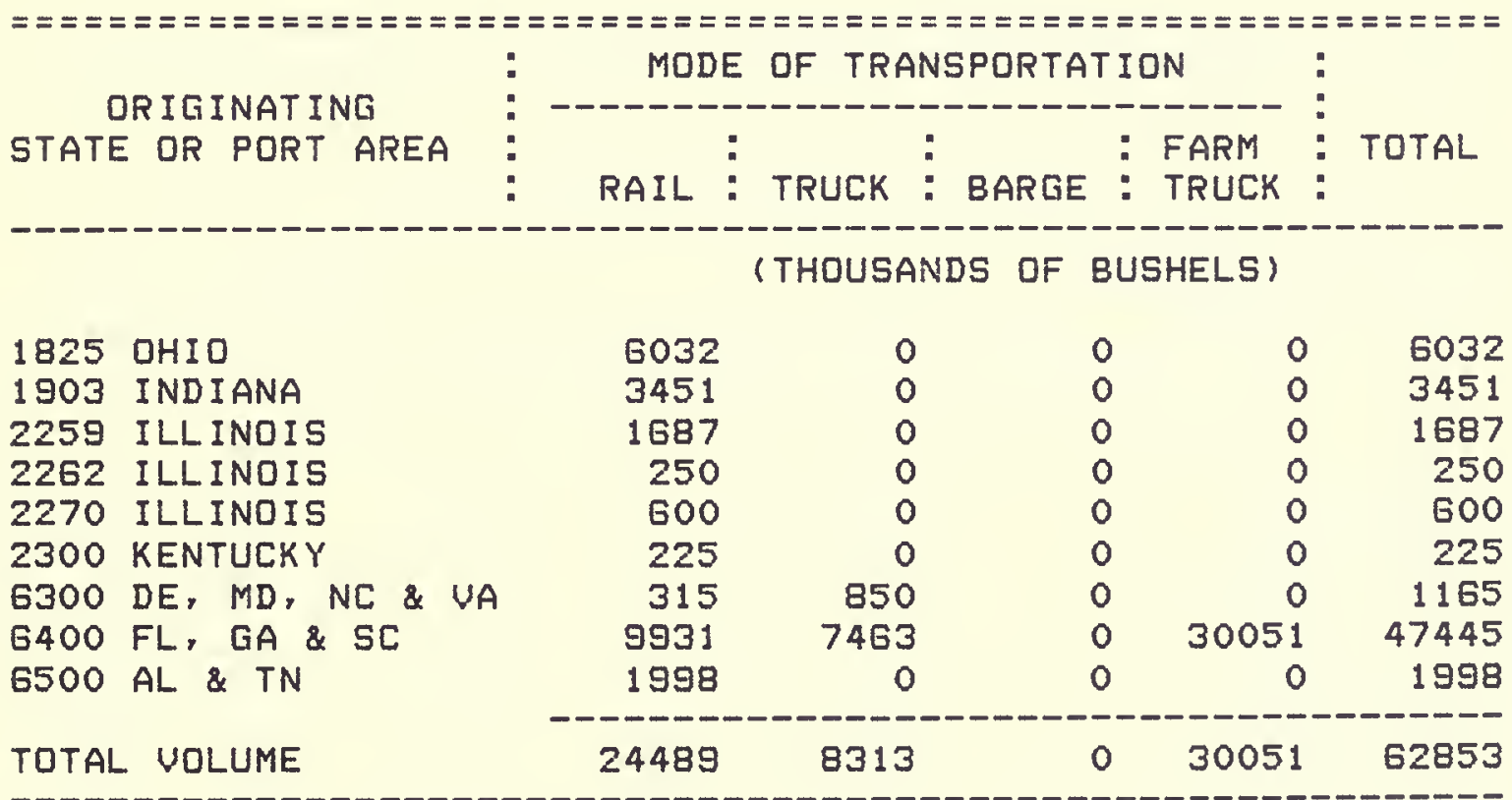


TABLE 84. 1977 SOYBEAN SHIPMENTS TO UARIOUS DESTINATIONS BY FIRMS IN AREA 6400, FL, GA \& SC

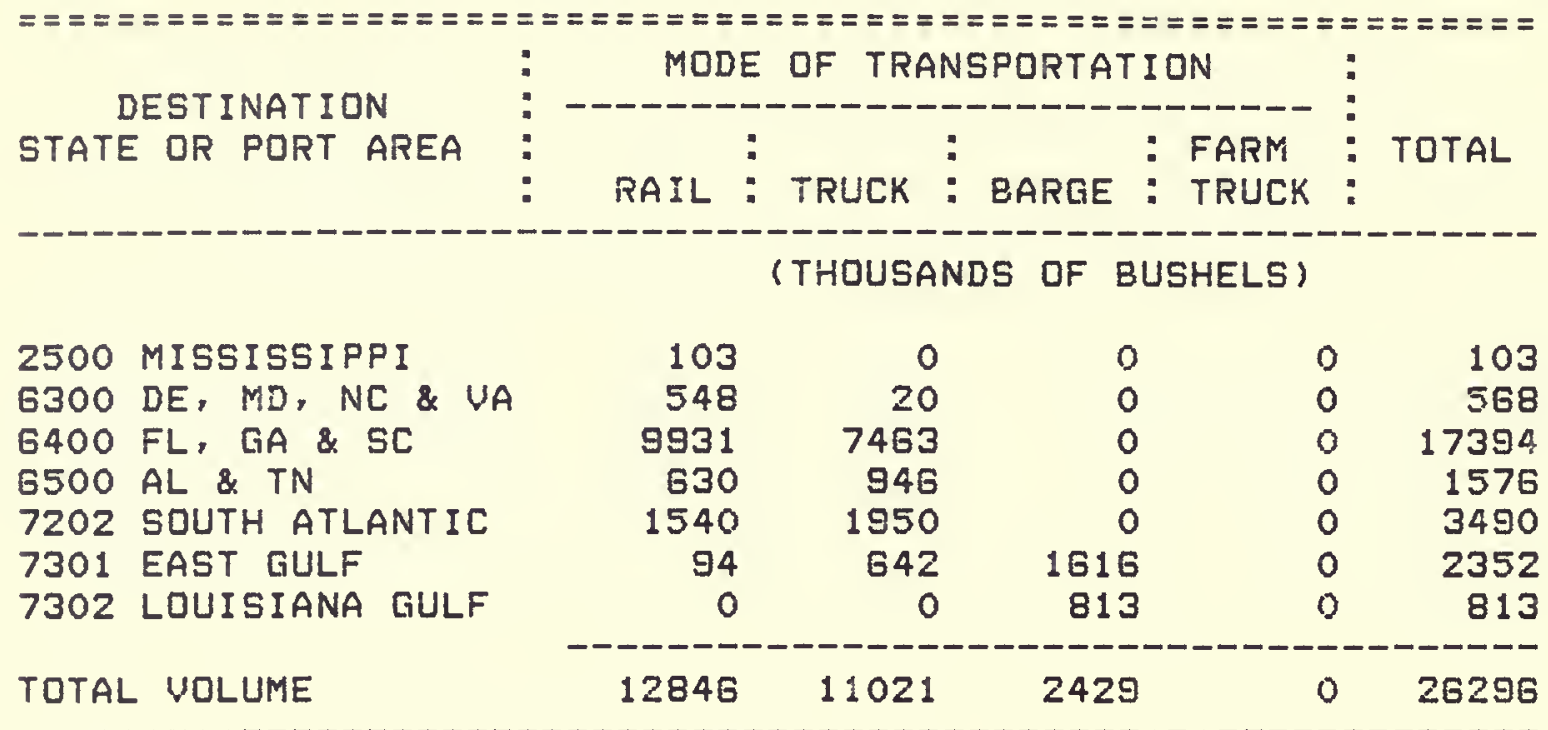

TABLE 85. 1977 SOYBEAN RECEIPTS FROM UARIOUS ORIGINS BY FIRMS IN AREA 6500, AL \& TN

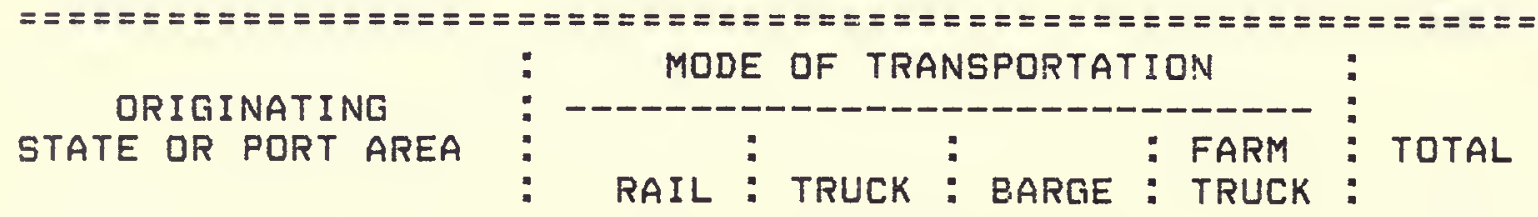

(THOUSANDS OF BUSHELS)

\begin{tabular}{|c|c|c|c|c|c|c|}
\hline 1825 & OHIO & 1572 & 0 & 507 & 0 & 2079 \\
\hline 1903 & INDIANA & 1272 & 0 & 475 & 0 & 1747 \\
\hline 2256 & ILLINOIS & 0 & 0 & 4321 & 0 & 4321 \\
\hline 2258 & ILLINOIS & 110 & 0 & 0 & 0 & 110 \\
\hline 2259 & ILLINOIS & 5004 & 0 & 0 & 0 & 5004 \\
\hline 2260 & ILLINOIS & 0 & 0 & 3069 & 0 & 3069 \\
\hline 2262 & ILLINOIS & 7709 & 0 & 3150 & 0 & 10859 \\
\hline 2300 & KENTUCKY & 3594 & 1831 & 287 & 450 & 6162 \\
\hline 2500 & MISSISSIPPI & 755 & 2593 & 0 & 490 & 3838 \\
\hline 2803 & IOWA & 0 & 0 & 587 & 0 & 587 \\
\hline 2900 & MISSOUR I & 277 & 0 & 2000 & 0 & 2277 \\
\hline 3000 & ARKANSAS & 178 & 631 & 0 & 536 & 1345 \\
\hline 6400 & $F L, G A \& S C$ & 630 & 946 & 0 & 0 & 1576 \\
\hline 6500 & $A L \& T N$ & 12160 & 59265 & 2792 & 78560 & 152777 \\
\hline 6600 & $K S$ NE & 66 & 0 & 0 & 0 & 66 \\
\hline TOT & VOLUME & 33327 & 65266 & 17188 & 80036 & 195817 \\
\hline
\end{tabular}


TABLE 86. 1977 SOYBEAN SHIPMENTS TO UARIOUS DESTINATIONS BY FIRMS IN AREA 6500, AL \& TN

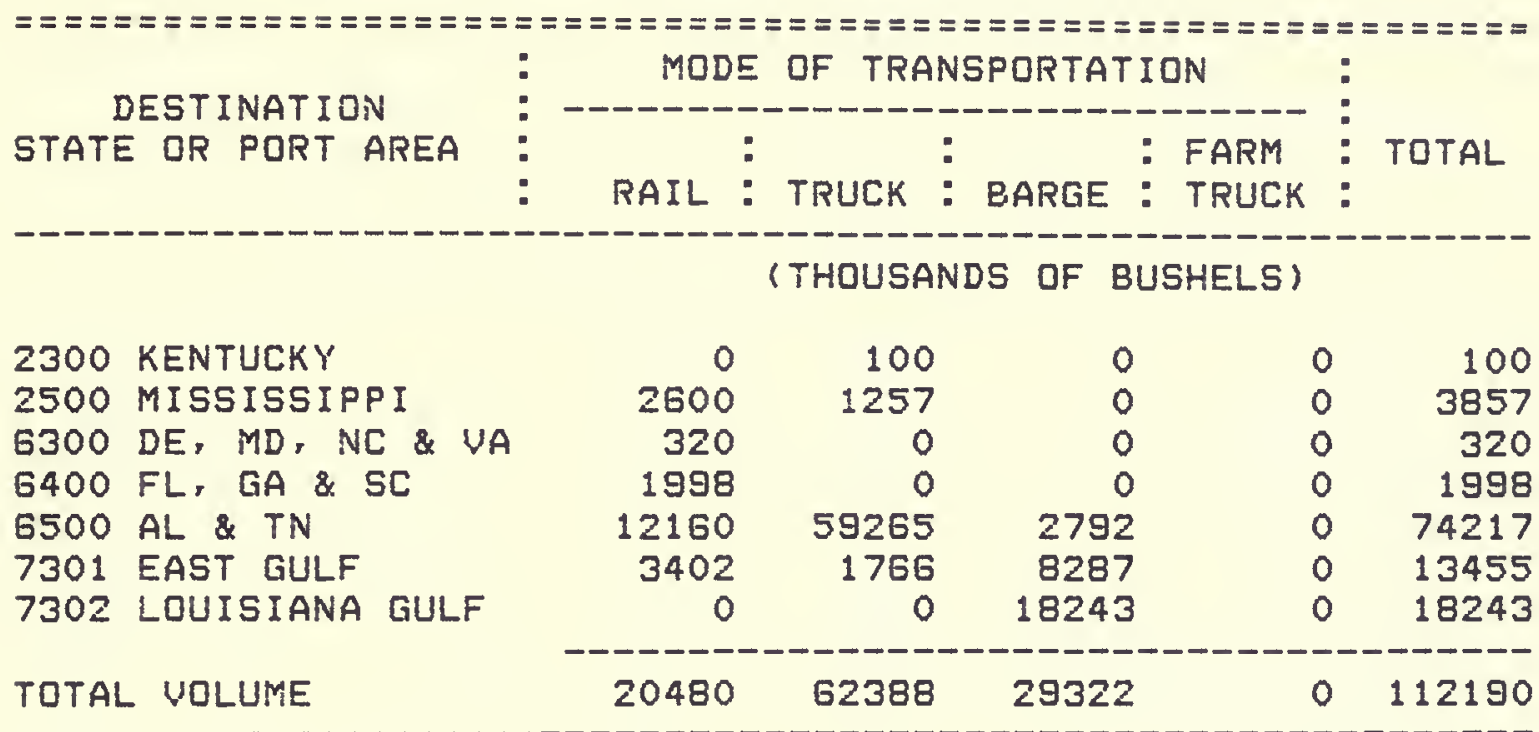

TABLE 87. 1977 SOYBEAN RECEIPTS FROM UARIQUS ORIGINS BY FIRMS IN AREA 6GOO, KS \& NE

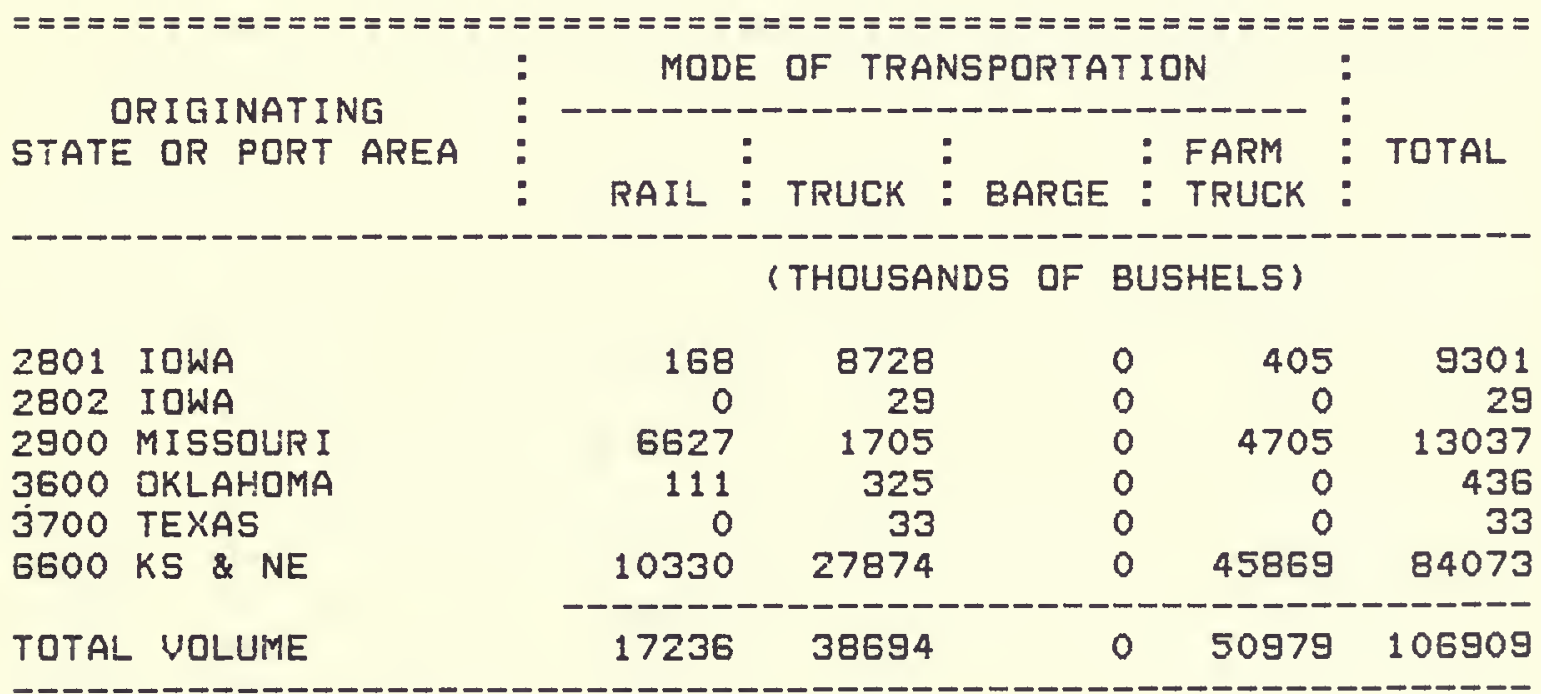


TABLE 88. 1977 SOYBEAN SHIPMENTS TO VARIOUS DESTINATIONS BY FIRMS IN AREA GGOO, KS \& NE

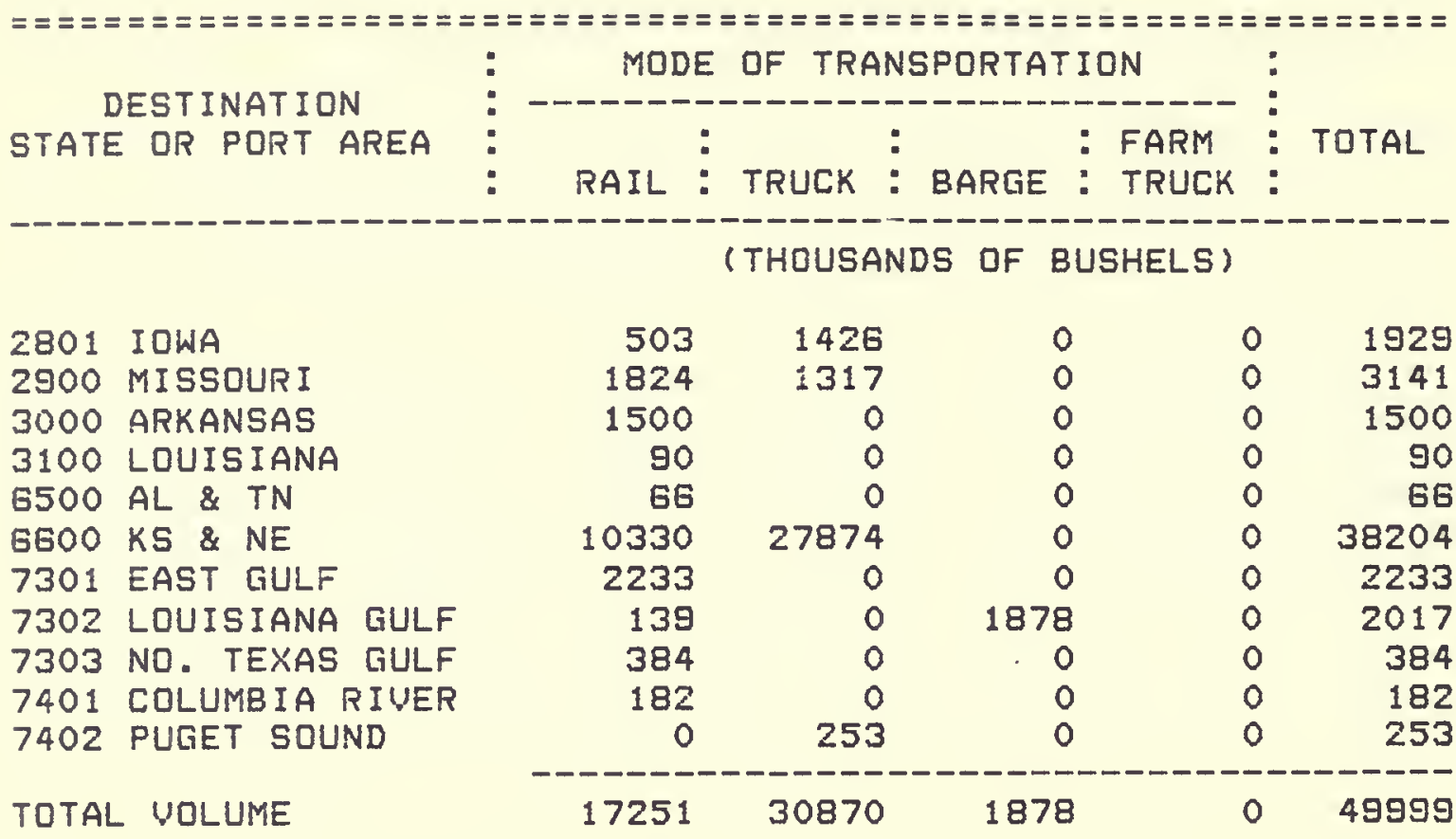

TABLE 89. 1977 SOYBEAN RECEIPTS FROM UARIOUS ORIGINS BY FIRMS IN AREA 7102, CHICAGO AREA

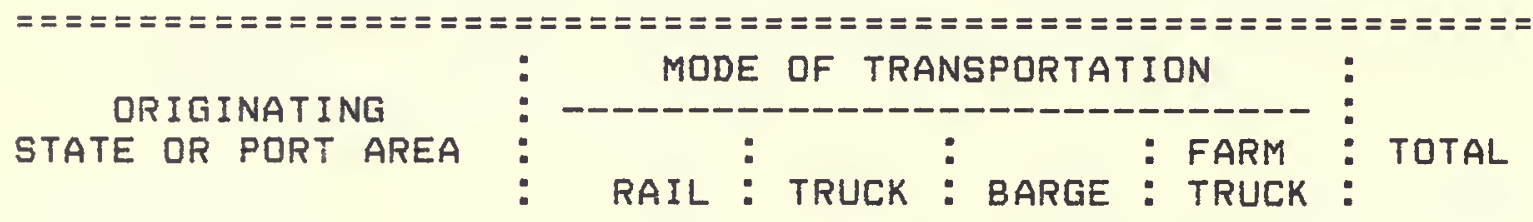

(THOUSANDS OF BUSHELS)

$\begin{array}{llrrrrr}1901 & \text { INDIANA } & 0 & 9538 & 0 & 0 & 9538 \\ 1902 & \text { INDIANA } & 0 & 995 & 0 & 0 & 995 \\ 2000 \text { MICHIGAN } & 0 & 1378 & 0 & 0 & 1378 \\ 2100 & \text { WISCONSIN } & 1432 & 3015 & 0 & 735 & 5182 \\ 2256 & \text { ILLINOIS } & 1452 & 4769 & 1321 & 52 & 7594 \\ 2257 & \text { ILLINOIS } & 500 & 888 & 0 & 0 & 1388 \\ 2801 & \text { IOWA } & 2040 & 0 & 0 & 0 & 2040 \\ 2802 & \text { IOWA } & 624 & 194 & 0 & 0 & 818 \\ 2803 & \text { IOWA } & 0 & 447 & 0 & 0 & 447 \\ 7102 \text { CHICAGO } \text { AREA } & 111 & 0 & 0 & 0 & 111 \\ \text { TOTAL UOLUME } & ---1159 & 21224 & 1321 & 787 & 29491\end{array}$


TABLE 90. 1977 SOYBEAN SHIPMENTS TO UARIOUS DESTINATIONS BY FIRMS IN AREA 7102, CHICAGO AREA

= = = = = = = = = = = = = = = = = = = = = = = = = = = = = = = = = = = = = = = = = = = = = = =

DESTINATION

STATE OR PORT AREA
MODE OF TRANSPORTATION

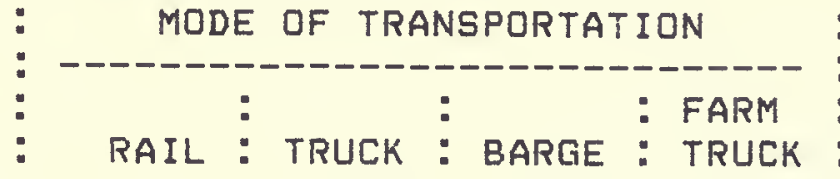

TOTAL

(THOUSANDS OF BUSHELS)

1901 INDIANA

2256 ILLINOIS

G300 DE, MD, NC \& UA

7102 CHICAGC AREA

7201 NORTH ATLANTIC

7202 SOUTH ATLANTIC

7302 LOUISIANA GULF

9000 EXPORT

TOTAL VOLUME

$\begin{array}{rrrrr}393 & 0 & 0 & 0 & 393 \\ 0 & 200 & 0 & 0 & 200 \\ 327 & 0 & 0 & 0 & 327 \\ 111 & 0 & 0 & 0 & 111 \\ 2055 & 0 & 0 & 0 & 2055 \\ 811 & 0 & 0 & 0 & 811 \\ 0 & 0 & 1670 & 0 & 1670 \\ 669 & 202 & 14995 & 0 & 15866 \\ -1366 & 402 & 16665 & 0 & 21433\end{array}$

TABLE 91. 1977 SOYBEAN RECEIPTS FROM UARIOUS ORIGINS BY FIRMS IN AREA 7103, TOLEDO AREA

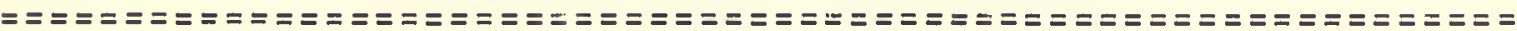

OR I GINAT ING STATE OR PORT AREA
MODE OF TRANSPORTATION

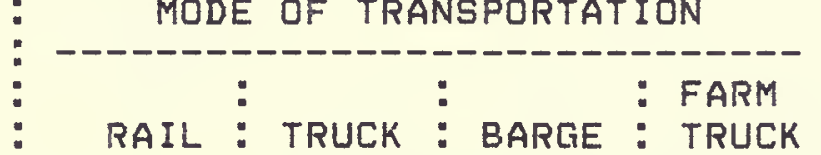

\section{(THOUSANDS OF BUSHELS)}

$\begin{array}{llrcrrr}1825 & \text { OHIO } & 0 & 4747 & 0 & 0 & 4747 \\ 1850 \text { OHIO } & 3713 & 21359 & 0 & 1254 & 26326 \\ 1901 \text { INDIANA } & 350 & 1774 & 0 & 296 & 2420 \\ 2000 \text { MICHIGAN } & 0 & 11510 & 0 & 1792 & 13302 \\ \text { TOTAL YOLUME } & --1--0-102 & 0 & 3342 & 46795\end{array}$

TABLE 92. 1977 SOYBEAN SHIPMENTS TO UARIOUS DESTINATIONS BY FIRMS IN AREA 7103, TOLEDO AREA

= = = = = = = = = = = = = = = = = = = = = = = = = = = = = = = = = = = = = = = = = = = = = = = = =

DESTINATION

STATE OR PORT AREA
MODE OF TRANSPORTATION

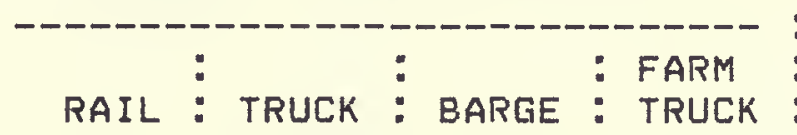

TOTAL

(THOUSANDS OF BUSHELS)

9000 EXPORT

TOTAL VOLUME

\begin{tabular}{ccccr}
0 & 0 & 47088 & 0 & 47088 \\
\hline 0 & 0 & 47088 & 0 & 47088
\end{tabular}


TABLE 93. 1977 SOYBEAN RECEIPTS FROM UARIOUS ORIGINS BY FIRMS IN AREA 7104, SAGINAW AREA

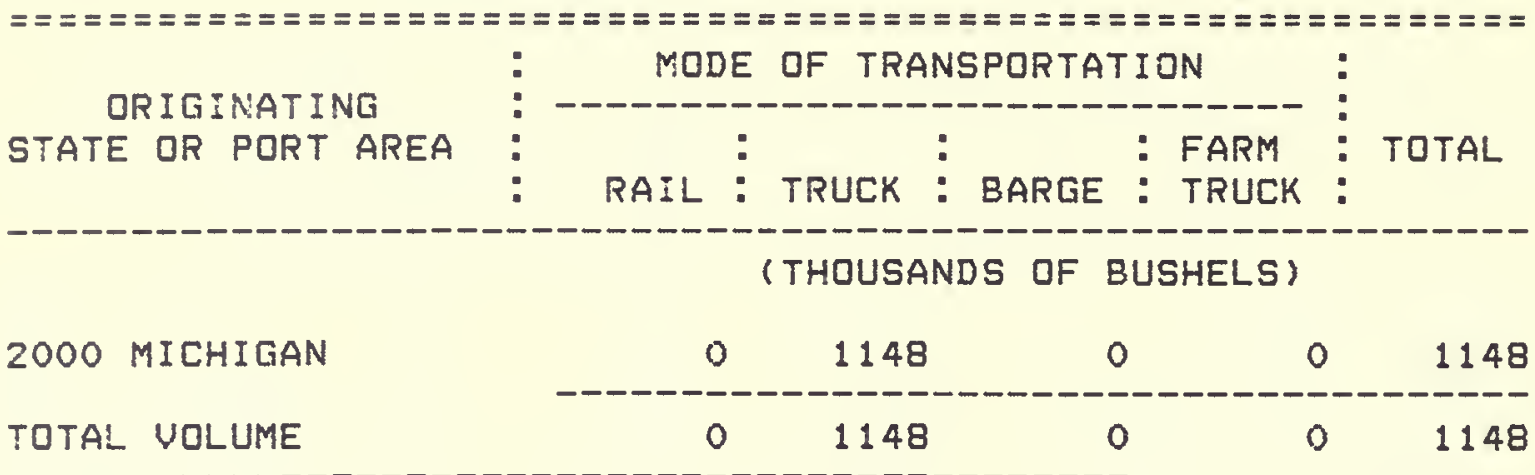

TABLE 94. 1977 SOYBEAN SHIPMENTS TO UARIOUS DESTINATIONS BY FIRMS IN AREA 7104, SAGINAW AREA

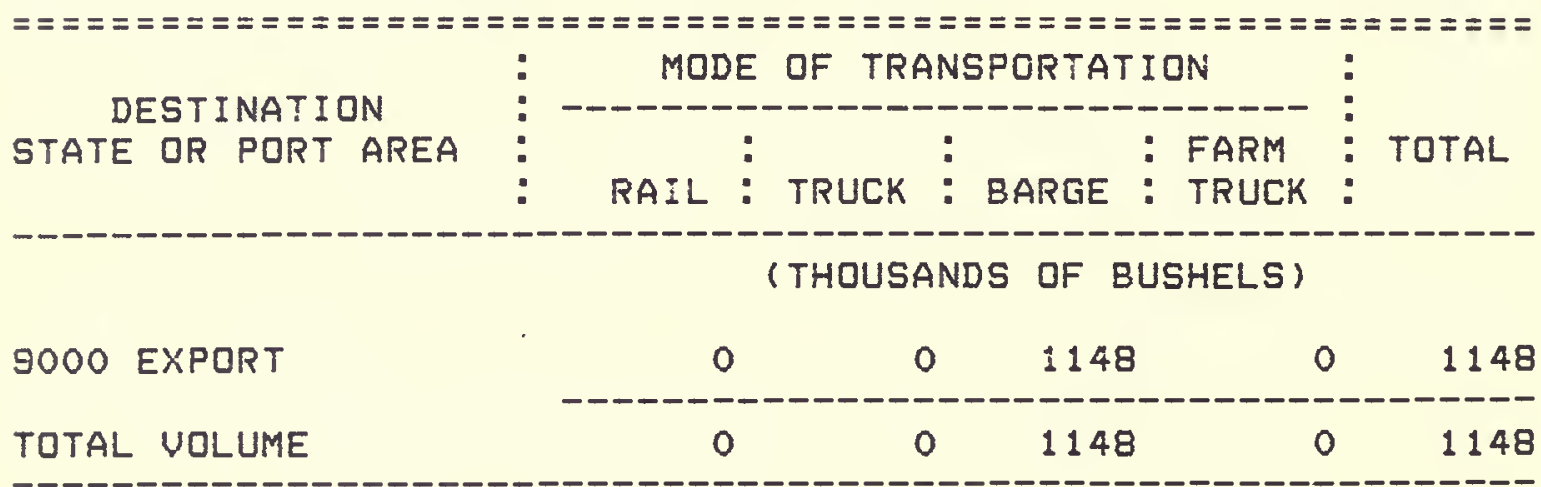

TABLE 95. 1977 SOYBEAN RECEIPTS FROM UARIOUS ORIGINS BY FIRMS IN AREA 7201, NORTH ATLANTIC

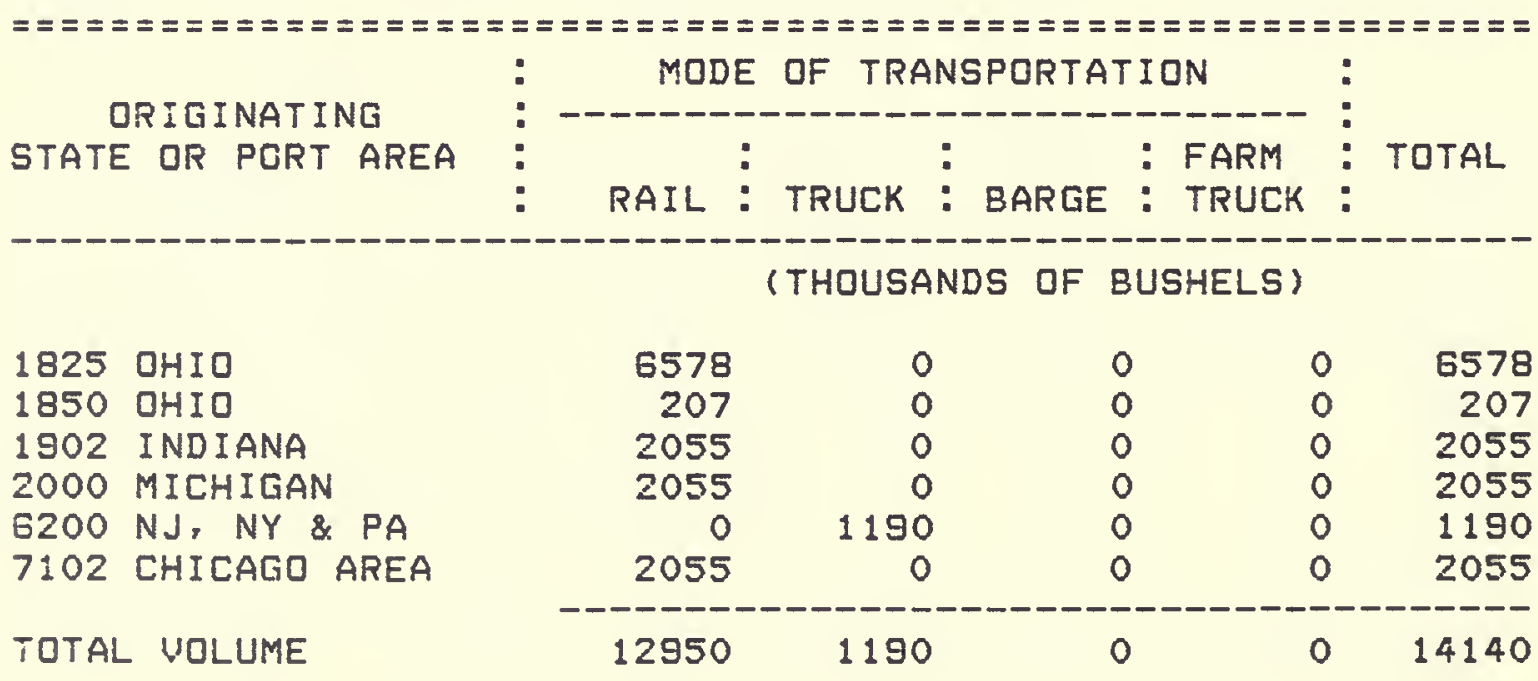


TABLE 96. 1977 SOYBEAN SHIPMENTS TO UARIOUS DESTINATIONS BY FIRMS IN AREA 7201, NORTH ATLANTIC

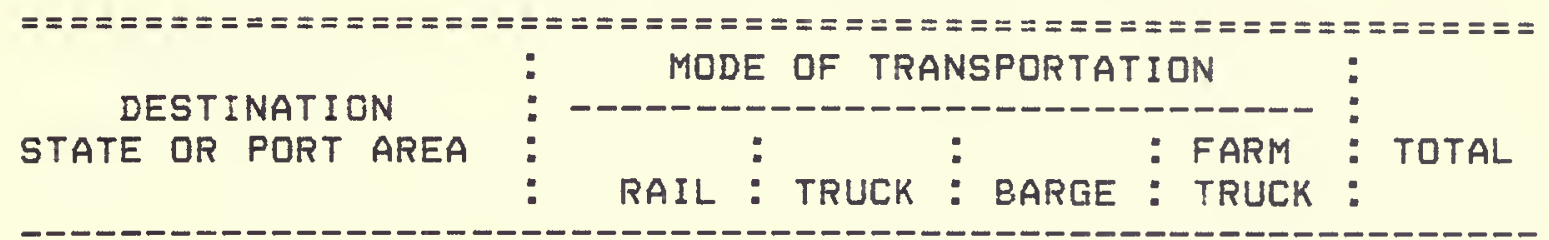

(THOUSANDS OF BUSHELS)

SOOO EXPORT

TOTAL VOLUME

\begin{tabular}{ccccr}
0 & 0 & 13802 & 0 & 13802 \\
\hline 0 & 0 & 13802 & 0 & 13802
\end{tabular}

TABLE 97. 1977 SOYBEAN RECEIPTS FROM VARIOUS ORIGINS BY FIRMS IN AREA 7202, SOUTH ATLANTIC

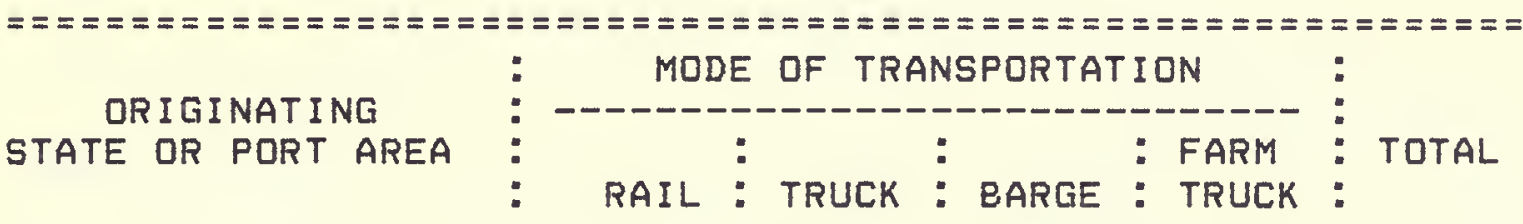

(THOUSANDS OF BUSHELS)

\begin{tabular}{|c|c|c|c|c|c|c|}
\hline 1825 & OHIO & 6339 & 0 & 0 & 0 & 6339 \\
\hline 1850 & OHIO & 12953 & 0 & 0 & 0 & 12953 \\
\hline 1901 & INDIANA & 4727 & 0 & 0 & 0 & 4727 \\
\hline 1902 & INDIANA & 16167 & 0 & 0 & 0 & 16167 \\
\hline 2000 & MICHIGAN & 2000 & 0 & 0 & 0 & 2000 \\
\hline 2257 & ILLINOIS & 1112 & 0 & 0 & 0 & 1112 \\
\hline 2258 & ILLINOIS & 335 & 0 & 0 & 0 & 335 \\
\hline 2801 & I OWA & 377 & 0 & 0 & 0 & 377 \\
\hline 2802 & IOWA & 52 & 0 & 0 & 0 & 52 \\
\hline 6200 & NJ, NY \& PA & 0 & 73 & 0 & 60 & 133 \\
\hline 6300 & $D E, M D, N C \&$ UA & 991 & 1436 & 5119 & 140 & 7686 \\
\hline 6400 & $F L, G A \& S C$ & 1540 & 1950 & 0 & G00 & 4090 \\
\hline 7102 & CHICAGO AREA & 811 & 0 & 0 & 0 & 811 \\
\hline ITAL & VOLUME & 47404 & 3459 & 5119 & 800 & 5678 \\
\hline
\end{tabular}


TABLE 98. 1977 SOYBEAN SHIPMENTS TO VARIOUS DESTINATIONS BY FIRMS IN AREA 7202, SOUTH ATLANTIC

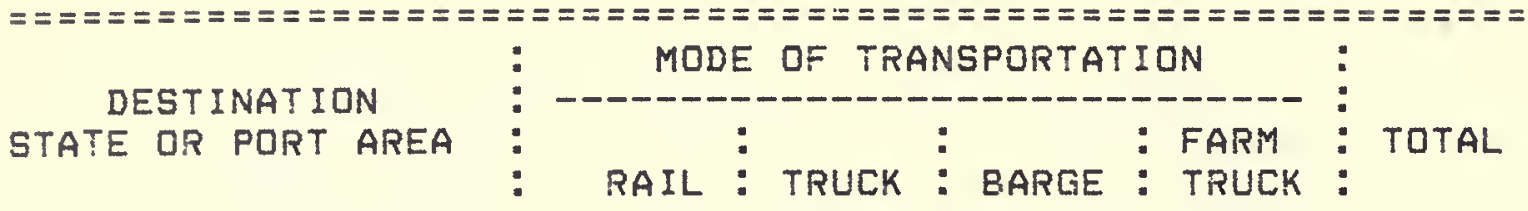

(THOUSANDS OF BUSHELS)

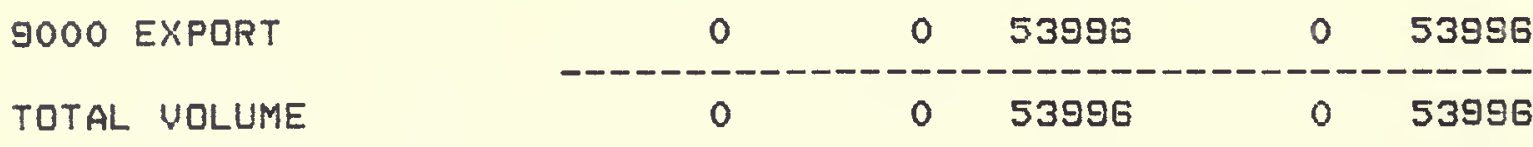

TABLE 99. 1977 SOYBEAN RECEIPTS FROM UARIOUS ORIGINS BY FIRMS IN AREA 7301, EAST GULF

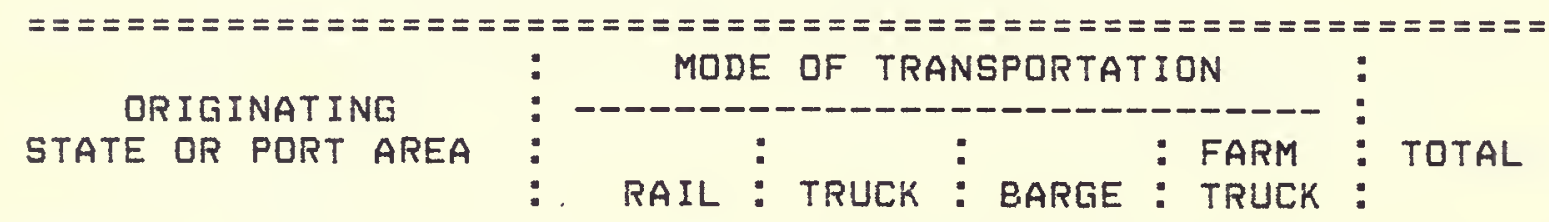

(THOUSANDS OF BUSHELS)

\begin{tabular}{|c|c|c|c|c|c|c|}
\hline 1825 & DHIO & 164 & 0 & 0 & 0 & 164 \\
\hline 1901 & INDIANA & 212 & 0 & 0 & 0 & 212 \\
\hline 1903 & INDIANA & 329 & 0 & 87 & 0 & 416 \\
\hline 2256 & ILLINOIS & 0 & 0 & 2000 & 0 & 2000 \\
\hline 2259 & ILLINOIS & 621 & 0 & 0 & 0 & 621 \\
\hline 2260 & ILLINOIS & 0 & 0 & 6528 & 0 & 6528 \\
\hline 2262 & ILLINOIS & 685 & 0 & 1400 & 0 & 2085 \\
\hline 2500 & MISSISSIPPI & 5330 & 111 & 144 & 0 & 5585 \\
\hline 2703 & MINNESGTA & 3636 & 0 & 0 & 0 & 3636 \\
\hline 2705 & MINNESOTA & 0 & 0 & 50 & 0 & 50 \\
\hline 2801 & IOWA & 2338 & 0 & 0 & 0 & 2338 \\
\hline 2802 & IOWA & 3782 & 0 & 0 & 0 & 3782 \\
\hline 2803 & IOWA & 88 & 0 & 403 & 0 & 491 \\
\hline 2900 & MISSOURI & 575 & 0 & 153 & 0 & 728 \\
\hline 3000 & ARKANSAS & 8163 & 2370 & 12713 & 0 & 23246 \\
\hline 3600 & OKLAHOMA & 0 & 0 & 350 & 0 & 350 \\
\hline 6400 & $F L, ~ G A \& S C$ & 94 & 642 & 1616 & 0 & 2352 \\
\hline 6500 & $A L \& T N$ & 3402 & 1766 & 8287 & 850 & 14305 \\
\hline G6OO & KS \& NE & 2233 & 0 & 0 & 0 & 2233 \\
\hline TOTAL & - VOLUME & 31652 & $48 B 9$ & 33731 & 850 & 71122 \\
\hline
\end{tabular}


TABLE 100. 1977 SOYBEAN SHIPMENTS TO UARIOUS DESTINATIONS BY FIRMS IN AREA 7301, EAST GULF

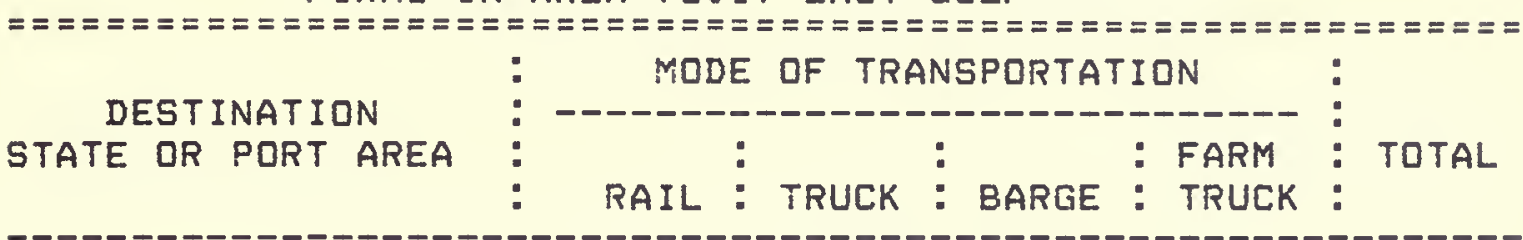

(THOUSANDS OF BUSHELS)

9000 EXPORT

$\begin{array}{lllll}0 & 0 & 68325 & 0 & 68325\end{array}$

TOTAL UDLUME

0

0 68325

$0 \quad 68325$

TABLE 101. 1977 SOYBEAN RECEIPTS FROM UARIOUS ORIGINS BY FIRMS IN AREA 7302, LOUISIANA GULF

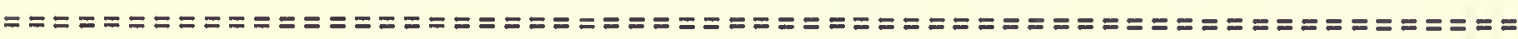

DRIGINATING

STATE DR PDRT AREA
MODE OF TRANSPORTATION

------------------------------

RAIL : TRUCK : BARGE : FARM

TOTAL

1825 DHID

1903 INDIANA

2100 WISCDNSIN

2256 ILLINOIS

2257 ILLINOIS

2258 ILLINOIS

2259 ILLINOIS

2260 ILLINOIS

2261 ILLINOIS

2262 ILLINOIS

2300 KENTUCKY

2500 MISSISSIPPI

2705 MINNESOTA

2801 IOWA

2802 IOWA

2803 IOWA

2900 MISSOURI

3000 ARKANSAS

3100 LOUISIANA

3600 OKLAHOMA

3700 TEXAS

$6400 \mathrm{FL}, \mathrm{GA} \& \mathrm{SC}$

6500 AL \& TN

$6600 \mathrm{KS}$ \& NE

7102 CHICAGO AREA
(THOUSANDS OF BUSHELS)

\begin{tabular}{|c|c|c|c|c|}
\hline 0 & 0 & 10496 & 0 & 10496 \\
\hline 50 & 0 & 8033 & 0 & 8083 \\
\hline 0 & 0 & 1350 & 0 & 1350 \\
\hline 0 & 0 & 36158 & 0 & 36158 \\
\hline 1135 & 0 & 0 & 0 & 1135 \\
\hline 647 & 0 & 0 & 0 & 647 \\
\hline 0 & 0 & 3483 & 0 & 3483 \\
\hline 0 & 0 & 23614 & 0 & 23614 \\
\hline 0 & 0 & 13042 & 0 & 13042 \\
\hline 305 & 0 & 21323 & 0 & 21628 \\
\hline 21 & 0 & 11393 & 0 & 1141 \\
\hline 2002 & GG & 26239 & 0 & 28307 \\
\hline 0 & 0 & 24490 & 0 & 24490 \\
\hline 12260 & 0 & 848 & 0 & 13108 \\
\hline 6208 & 0 & 0 & 0 & 6208 \\
\hline 341 & 0 & 28469 & 0 & 2BB1 \\
\hline 0 & 0 & 40777 & 0 & 40777 \\
\hline 6149 & 989 & 25873 & 0 & 33011 \\
\hline 1613 & 9744 & 45381 & 0 & 56738 \\
\hline 0 & 0 & 1900 & 0 & 190 \\
\hline 360 & 0 & 0 & 0 & 36 \\
\hline 0 & 0 & 813 & 0 & $81:$ \\
\hline 0 & 0 & 18243 & 0 & $1824:$ \\
\hline 139 & 0 & 1878 & 0 & 201 \\
\hline 0 & 0 & 1670 & 0 & 1670 \\
\hline 31230 & 10799 & 345473 & 0 & 38750 \\
\hline
\end{tabular}

TOTAL VOLUME 
TABLE 102. 1977 SOYBEAN SHIPMENTS TO VARIOUS DESTINATIONS BY FIRMS IN AREA 7302, LOUISIANA GULF

= = = = = = = = = = = = = = = = = = = = = = = = = = = = = = = = = = = = = = = = = = = = = = = = =

DEST INAT I ON

STATE OR PORT AREA
MODE OF TRANSPORTATION

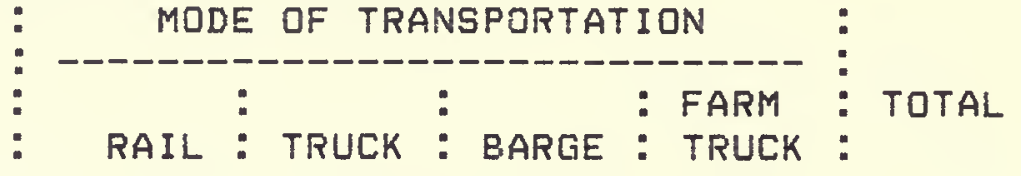

(THOUSANDS OF BUSHELS)
(THOS

9OOO EXPORT

TOTAL VOLUME

$\begin{array}{ccccr}0 & 0 & 368153 & 0 & 368153 \\ 0 & 0 & 368153 & 0 & 368153\end{array}$

TABLE 103. 1977 SOYBEAN RECEIPTS FROM UARIOUS ORIGINS EY

FIRMS IN AREA 7303, NO. TEXAS GIULF

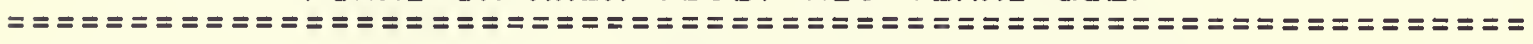

QR I G INAT ING

STATE OR PORT AREA

MODE OF TRANSPORTATION

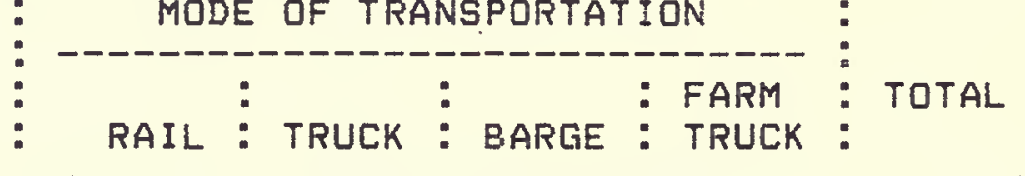

(THOUSANDS OF BUSHELS)

\begin{tabular}{|c|c|c|c|c|c|c|}
\hline 2259 & ILLINOIS & 320 & 0 & 0 & 0 & 320 \\
\hline 2703 & MINNESOTA & 396 & 0 & 0 & 0 & 396 \\
\hline 2801 & I OWA & 4150 & 0 & 0 & 0 & 4150 \\
\hline 2802 & I OWA & 1876 & 0 & 0 & 0 & 1876 \\
\hline 2803 & IOWA & 101 & 0 & 0 & 0 & 101 \\
\hline 2900 & MISSOUR I & 1229 & 0 & 0 & 0 & 1229 \\
\hline 3000 & ARKANSAS & 158 & 0 & 0 & 0 & 158 \\
\hline 3100 & LOUISIANA & 13 & 9421 & 0 & 0 & 9434 \\
\hline 3300 & SOUTH DAKOTA & 51 & 0 & 0 & 0 & 51 \\
\hline 3700 & TEXAS & 1923 & 1304 & 0 & 0 & 3227 \\
\hline 3789 & TEXAS & 0 & 6165 & 0 & 0 & 6165 \\
\hline 6600 & KS \& NE & 384 & 0 & 0 & 0 & 384 \\
\hline TOTAL & VOLUME & 10601 & 16890 & 0 & 0 & 27491 \\
\hline
\end{tabular}

TABLE 104. 1977 SOYBEAN SHIPMENTS TO VARIOUS DESTINATIONS BY FIRMS IN AREA 7303, NO. TEXAS GULF

= = = = = = = = = = = = = = = = = = = = = = = = = = = = = = = = = = = = = = = = = = = = = = =

DEST INATION

STATE OR PORT AREA

MODE OF TRANSPORTATION

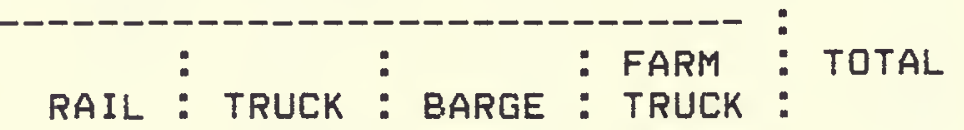

(THOUSANDS OF BUSHELS)

SOOO EXPORT

TOTAL VOLUME

$\begin{array}{ccccr}0 & 0 & 27450 & 0 & 27450 \\ 0 & 0 & 27450 & 0 & 27450\end{array}$


TABLE 105. 1977 SOYBEAN RECEIPTS FROM UARIOUS ORIGINS BY FIRMS IN AREA 7401, COLUMBIA RIUER

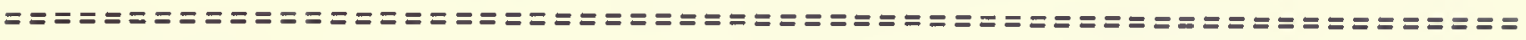

QR IGINAT ING

STATE OR PORT AREA
MODE DF TRANSPORTATION

RAIL: TRUCK : BARGE : FARMCK :

TOTAL

2703 MINNESOTA

3300 SDUTH DAKDTA

6600 KS \& NE

TOTAL WOLUME

(THOUSANDS OF BUSHELS)

\begin{tabular}{rrrrr}
349 & 0 & 0 & 0 & 349 \\
0 & 34 & 0 & 0 & 34 \\
182 & 0 & 0 & 0 & 182 \\
\hline 531 & 34 & 0 & 0 & 565
\end{tabular}

TABLE 1OE. 1977 SOYBEAN SHIPMENTS TO UARIDUS DESTINATIONS BY FIRMS IN AREA 7401, COLUMBIA RIUER

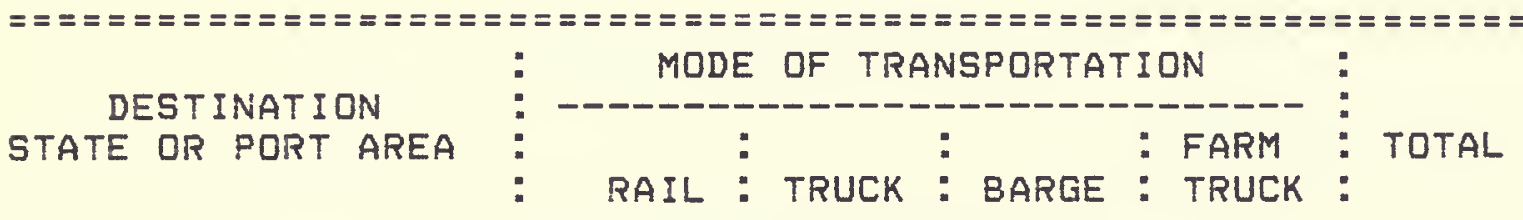

(THOUSANDS OF BUSHELS)

9OOO EXPORT

TOTAL VOLUME

\begin{tabular}{ccccr}
0 & 0 & 565 & 0 & 565 \\
\hline 0 & 0 & 565 & 0 & 565
\end{tabular}

TABLE 107. ¿977 SOYBEAN RECEIPTS FROM UARICUS ORIGINS BY FIRMS IN AREA 7402, PUGET SOUND

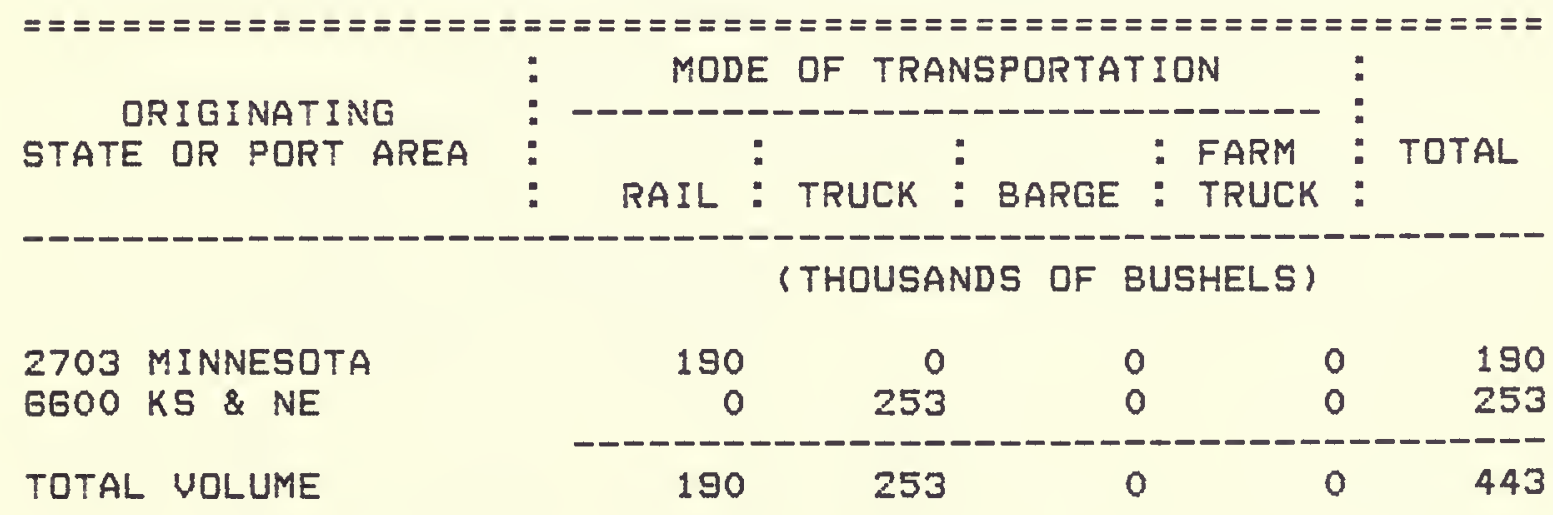

190 
TABLE 108. 1977 SOYBEAN SHIPMENTS TO VARIOUS DESTINATIONS BY FIRMS IN AREA 7402, PUGET SQUND

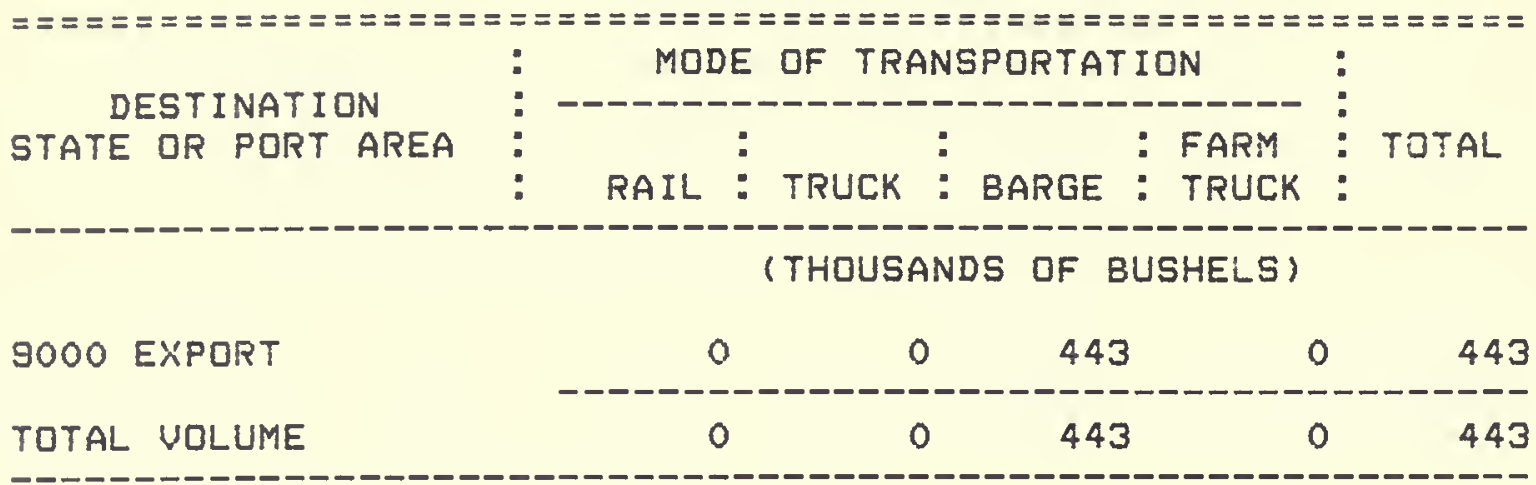

TABLE 109. 1977 SQYBEAN RECEIPTS FROM UARIOUS ORIGINS BY FIRMS IN AREA 7403, CALIFORNIA

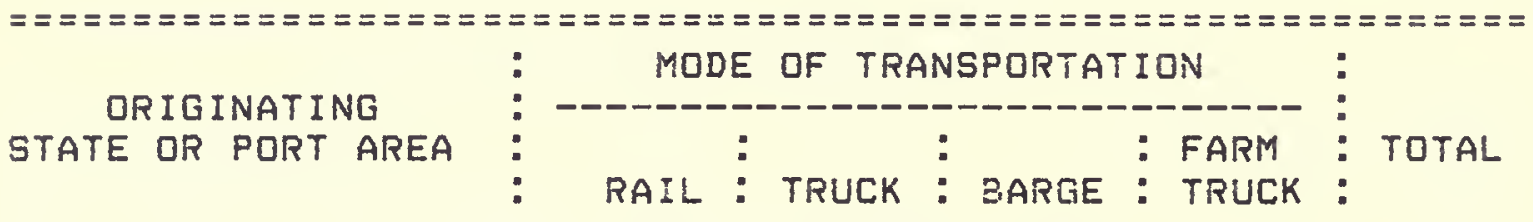

(THOUSANDS OF BUSHELS)

\begin{tabular}{|c|c|c|c|c|c|}
\hline 2801 IOWA & 295 & 0 & 0 & 0 & 295 \\
\hline TOTAL VOLUME & 295 & 0 & 0 & 0 & 29 \\
\hline
\end{tabular}

TABLE 110. 1977 SOYBEAN SHIPMENTS TO UARIOUS DESTINATIONS BY FIRMS IN AREA 7403, CALIFORNIA

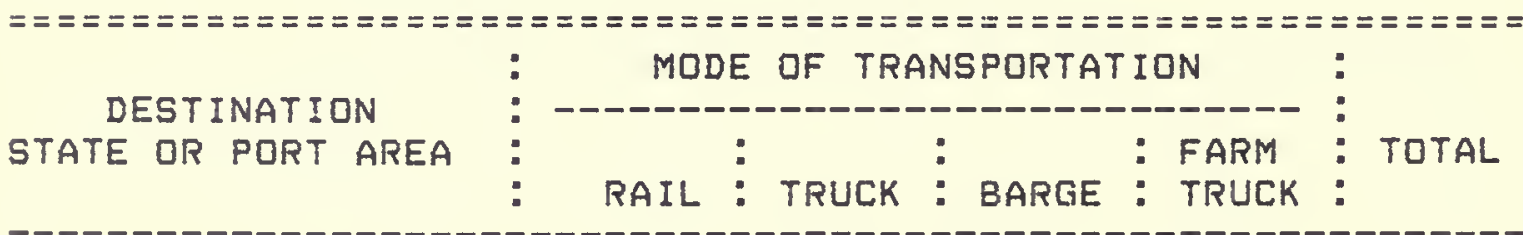

(THOUSANDS DF BUSHELS)

9000 EXPORT

TOTAL VOLUME

$\begin{array}{ccccr}0 & 0 & 295 & 0 & 295 \\ 0 & 0 & 295 & 0 & 295\end{array}$


$=\frac{1 x^{2} 8}{4 x^{2}}$

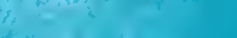





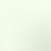

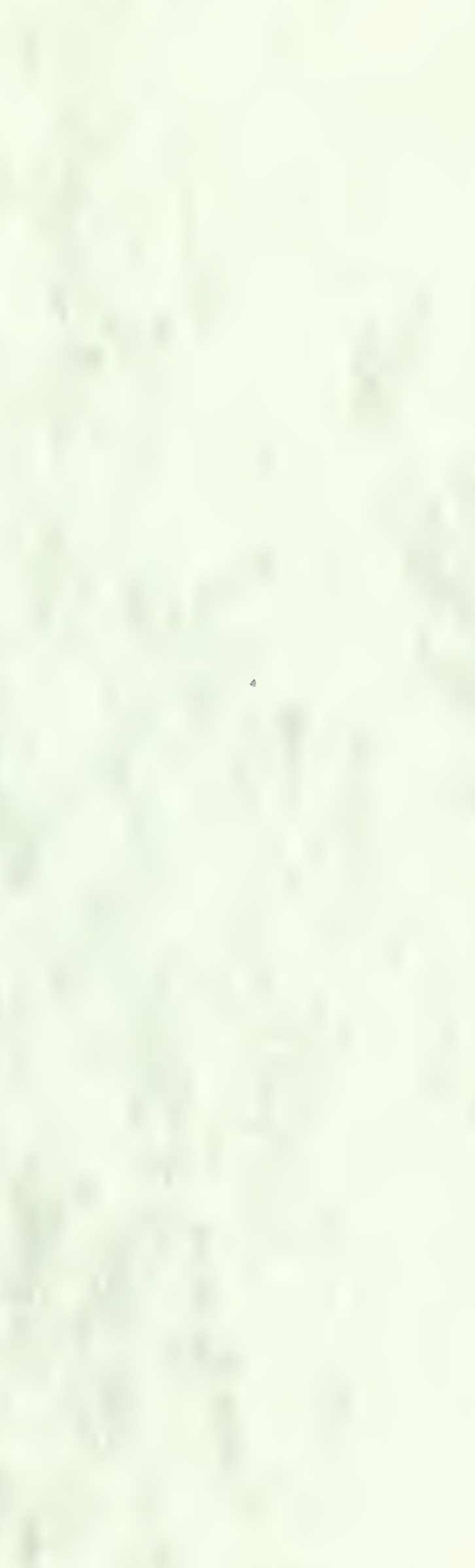


